\title{
The Behavior and Effects of the Noble Metals in the DWPF Melter System
}

by

M. E. Smith

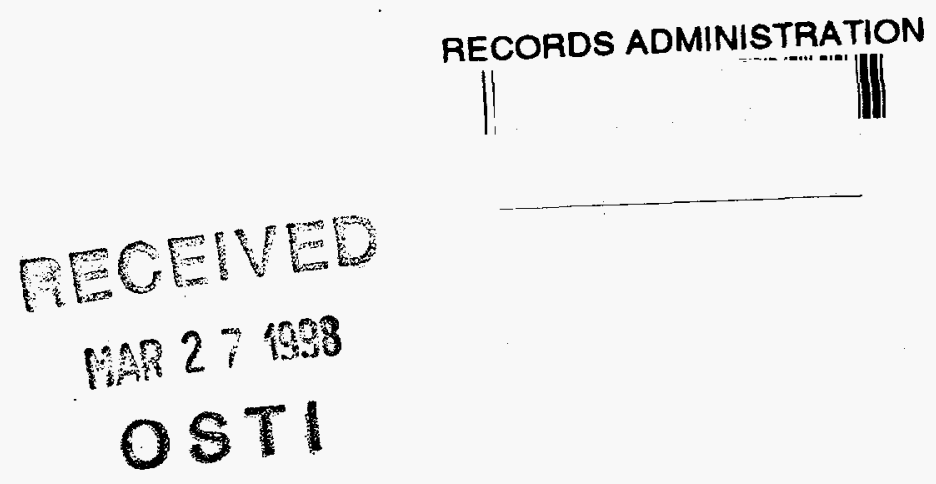

Westinghouse Savannah River Company

Savannah River Site

Aiken, South Carolina 29808

D. F. Bickford

DOE Contract No. DE-AC09-96SR18500

This paper was prepared in connection with work done under the above contract number with the U.S.

Department of Energy. By acceptance of this paper, the publisher and/or recipient acknowledges the U. S. Government's right to retain a nonexclusive, royalty-free license in and to any copyright covering this paper, along with the right to reproduce and to authorize others to reproduce all or part of the copyrighted paper. 
WSRC-TR-97-00370

Rev 0

\section{THE BEHAVIOR AND EFFECTS OF THE NOBLE METALS IN THE DWPF MELTER SYSTEM (U)}

\section{DENNIS F. BICKFORD}

MICHAEL E. SMITH

Westinghouse Savannah River Company Savannah River Technology Center Aiken, SC 29808 


\title{
DISCLAIMER
}

This report was prepared as an account of work sponsored by an agency of the United States Government. Neither the United States Government nor any agency thereof, nor any of their employees, makes any warranty, express or implied, or assumes any legal liability or responsibility for the accuracy, completeness, or usefulness of any information, apparatus, product, or process disclosed, or represents that its use would not infringe privately owned rights. Reference herein to any specific commercial product, process, or service by trade name, trademark, manufacturer, or otherwise does not necessarily constitute or imply its endorsement, recommendation, or favoring by the United States Government or any agency thereof. The views and opinions of authors expressed herein do not necessarily state or reflect those of the United States Government or any agency thereof.

This report has been reproduced directly from the best available copy.

Available to DOE and DOE contractors from the Office of Scientific and Technical Information, P.O. Box 62, Oak Ridge, TN 37831; prices available from (615) 576-8401.

Available to the public from the National Technical Information Service, U.S. Department of Commerce; 5285 Port Royal Road, Springfield, VA 22161.

\section{SAVANNAH RIVER TECHNOLOGY CENTER}

\author{
operated by \\ WESTINGHOUSE SAVANNAH RIVER COMPANY \\ for the \\ UNITED STATES DEPARTMENT OF ENERGY \\ under Contract DE-AC09-96SR18500
}




\section{DISCLAIMER}

Portions of this document may be illegible electronic image products. Images are produced from the best available original document. 
WSRC-TR-97-00370

Rev 0

Keywords: Ruthenium, Rhodium, Palladium, Glass, Joule-Heated

\section{THE BEHAVIOR AND EFFECTS OF THE NOBLE METALS IN THE DWPF MELTER SYSTEM (U)}

Dennis F. Bickford

Michael E. Smith

\section{INFORMATION ONLY}

Publication Date: November 30, 1997

Westinghouse Savannah River Company

Savannah River Technology Center

Aiken, SC 29808 
APPROVALS

Prepared by

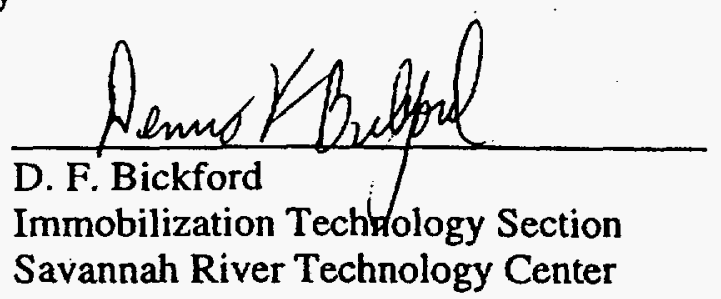

Savannah River Technology Center

miC. finish

M. E. Smith

Immobilization Technology Section

Savannah River Technology Center

Technical Reviewer

Damp. Lh

D. P. Lambert

Immobilization Technology Section

Savannah River Technology Center

Approved by

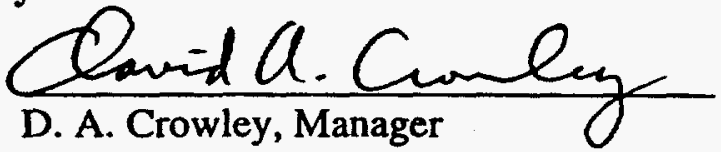

Glass Formulation and Melter Technology Group

Immobilization Technology Section

Savannah River Technology Center

EW Abetzahectio.

E. W. Holtzscheiter, Research Manager

Immobilization Technology Section

Savannah River Technology Center 


\begin{abstract}
Governments worldwide have committed to stabilization of high-level nuclear waste (HLW) by vitrification to a durable glass form for permanent disposal. All of these nuclear wastes contain the fission-product noble metals: ruthenium, rhodium, and palladium. SRS wastes also contain natural silver from iodine scrubbers. Closely associated with the noble metals are the fission products selenium and tellurium which are chemical analogs of sulfur and which combine with noble metals to influence their behavior and properties. Experience has shown that these melt insoluble metals and their compounds tend to settle to the floor of Joule-heated ceramic melters. In fact, almost all of the major research and production facilities have experienced some operational problem which can be associated with the presence of dense accumulations of these relatively conductive metals and/or their compounds. In most cases, these deposits have led to a loss of production capability, in some cases, to the point that melter operation could not continue.
\end{abstract}

HLW nuclear waste vitrification facilities in the United States are the Department of Energy's Defense Waste Processing Facility (DWPF) at the Savannah River Site, the planned Hanford Waste Vitrification Plant (HWVP) at the Hanford Site and the operating West Valley Demonstration Project (WVDP) at West Valley, NY.

The Integrated DWPF Melter System (IDMS) is a vitrification test facility at the Savannah River Technology Center (SRTC). It was designed and constructed to provide an engineering-scale representation of the DWPF melter and its associated feed preparation and off-gas treatment systems. An extensive noble metals testing program was begun in 1990. The objectives of this task were to explore the effects of the noble metals on the DWPF melter feed preparation and waste vitrification processes. This report focuses on the vitrification portion of the test program. 
List of Figures .................................................................. iv

List of Tables .................................................................... vi

List of Acronyms ...................................................................... vii

1.0 Summary and Recommendations ............................................

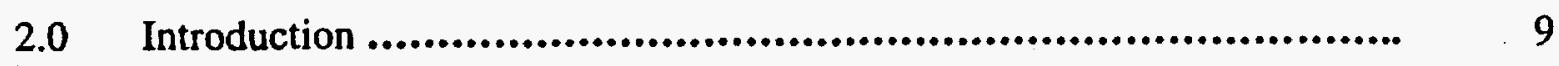

2.1 The Noble Metals ................................................... 9

2.2 Background (International Experience) .............................. 11

2.2.1 Testing in Japan ........................................... 12

2.2.2 Testing in the United Kingdom ............................. 14

2.2.3 Testing in France ........................................... 14

2.2.4 Testing in Germany and Belgium (PAMELA) ............. 14

$2.3 \quad$ Background (US Experience) ...................................... 20

2.3.1 Testing at the Pacific Northwest National Laboratory ...... $\quad 20$

2.3.2 Testing at the Savannah River Site ........................... 21

2.3.3 Testing at the West Valley Demonstration Project .......... 22

2.3.4 Path Forward for WVDP Noble Metals Concerns ............ 24

3.0 IDMS / DWPF System Description .......................................... 25

3.1 Feed Delivery System .............................................. 25

$3.2 \quad$ Melter System ....................................................... 26

3.3 Melter Offgas System ............................................... 30 
4.0 Summary of IDMS Noble Metals Runs ..................................... 31

4.1 Blend with Noble Metals (BL1, BL2) ................................ 31

4.2 DWPF Cold Runs Demonstrations (BL3, HM1) .................... 32

4.3 DWPF RadOp Design Basis Runs (HM2, HM3, PX1, PX2)......... 32

4.4 Hanford Waste Vitrification Plant Demonstration (HWVP1, HWVP2) 32

4.5 Nitric Acid Flowsheet - HAN PHA (HM4, PX3) .................... 32

4.6 Nitric Acid Flowsheet - Late Wash PHA (PX4, PX5, PX6) ......... 32

4.7 IDMS Melter Shutdown/Inspection .................................. 34

$5.0 \quad$ Behavior of the Noble Metals .................................................. 35

5.1 Size, Distribution and Chemical Form ............................... 35

5.1.1 In the Melter Feed Slurry ....................................... 35

5.1.2 In the Melter Cold Cap ........................................ 36

5.1.3 In the Melter Offgas Deposits / Offgas Condensate .......... 38

5.1.4 In the Canistered Glass Product ............................. 38

5.1.5 In the Melter Floor Samples ................................ 40

$5.2 \quad$ Noble Metals Material Balance ...................................... 50

5.2 .1 Analytical Measurements ................................... 50

5.2 .2 Material Balances ............................................. 51

5.2.3 Discharge Efficiency ....................................... 51

5.3 The Effects of Idling and Natural Convection ....................... 61

5.3.1 The Effects of Idling in the IDMS Melter ................... 61

5.3.2 The Effects of Concentration .................................. 63 
6.0 Results of the Post IDMS Melter Shutdown Floor Sampling ................ 65

7.0 Effects of Noble Metal Deposition on the Melter .......................... 65

7.1 Effects on the Melter Operation ................................... 65

7.2 Results of the Melter Inspection .................................. 70

8.0 Implications for the DWPF Melter Operation .......................... 73

Acknowledgments ..................................................................... 77

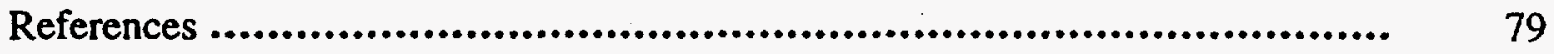

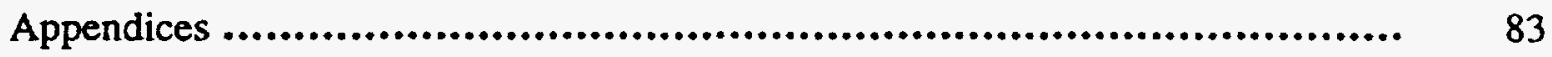




\section{List of Figures}

Page

1 The Noble Metals .

2 Japanese TVF $45^{\circ}$ Sloped Bottom Melter

3 German PAMELA Flat Bottom Melter

SEM Micrograph of IDMS Melter Cold Cap Sample (H-COLD-0238)

SEM Micrograph of IDMS Melter Cold Cap Sample (I-COLD-3690)

Top View of IDMS Melter Showing Points of Melter Floor Sampling .

IDMS Melter Floor Sample (I-MELT-4312) taken 8/23/91

IDMS Melter Floor Sample (I-MELT-4790) taken 10/15/91

21 Spinel Components ( $\mathrm{Cr}$ and $\mathrm{Ni}$ ) in Canistered Glass during Hanford Runs 
$28 \quad \mathrm{Ru}$ and $\mathrm{Rh}$ Analyses with Glass Production

$\mathrm{Ru}$ and $\mathrm{Rh}$ Discharge Efficiency .

Pd and Te Discharge Efficiency

IDMS Cumulative Glass Production

(a) Ruthenium Concentration in IDMS Glass versus Idling Time, (b) Hypothetical ..... Sedimentation Curve, (c) Linear Relationship between Ru Concentration and Idling Time

39 IDMS Melter Upper and Lower Electrode Currents (Amperes)

40 IDMS Melter Upper and Lower Melt Resistivities (Ohms)

41 IDMS Melter Upper-to-Lower Resistivity Ratio

42 IDMS Melter Upper Melt Pool Temperature $\left({ }^{\circ} \mathrm{C}\right)$ and Upper Electrode Current ....

43 IDMS Melter Upper Melt Pool Temperature $\left({ }^{\circ} \mathrm{C}\right)$ and Upper Melt Pool Resistivity (Ohms) 
1 Chemical and Physical Properties of the Noble Metals

2 Noble Metals in German, Japanese, and American Waste Glasses

3 Noble Metals Concentrations in Bottom Residue of German K-W2 Melter

4 IDMSIDWPF Melter Comparison

5 Characteristics of Melter Electrodes

6 Additive Form of Noble Metals, etc.

7 IDMS Run Summary

8 Analysis of IDMS Melter Floor Samples

9 Wt\% Concentration of Spinel and Noble Metals (Ru, Rh, and Pd) from IDMS Floor Samples 


$\begin{array}{ll}\text { AA: } & \text { Atomic Absorption } \\ \text { ADS: } & \text { Analytical Development Section of SRTC } \\ \text { BDL: } & \text { Below Detection Limit } \\ \text { CPC: } & \text { Chemical Processing Cell } \\ \text { DWPF: } & \text { Defense Waste Processing Facility } \\ \text { DWPT: } & \text { Defense Waste Processing Technology Section of SRTC } \\ \text { EDX: } & \text { Energy Dispersive X-Ray } \\ \text { HEWC: } & \text { High Enrichment Waste Concentrate } \\ \text { HWVP1: } & \text { First Run of the HWVP Process Demonstration } \\ \text { HWVP2: } & \text { Second Run of the HWVP Process Demonstration } \\ \text { HWVP: } & \text { Hanford Waste Vitrification Plant } \\ \text { IC: } & \text { Ion Chromatography } \\ \text { ICP: } & \text { Inductively Coupled Plasma } \\ \text { ICP-AES: } & \text { Inductively Coupled Plasma - Atomic Emission Spectroscopy } \\ \text { ICP-MS: } & \text { Inductively Coupled Plasma - Mass Spectrometry } \\ \text { IDMS: } & \text { Integrated DWPF Melter System } \\ \text { INE/KfK: } & \text { Institute fur Nuklear Entsorgungstechnik at } \\ & \text { Kernforshungzentrum Karslruhe (Nuclear Fuel Cycle Center) } \\ \text { LEWC: } & \text { Low Enrichment Waste Concentrate } \\ \text { LIMS: } & \text { Laboratory Information Management System } \\ \text { MFT: } & \text { Melter Feed Tank } \\ \text { NCAW: } & \text { Neutralized Current Acid Waste } \\ \text { OGCT: } & \text { Off Gas Condensate Tank } \\ \text { PHEF: } & \text { Precipitate Hydrolysis Experimental Facility } \\ \text { PNNL: } & \text { Battelle Pacific Northwest National Laboratory } \\ \text { RWS: } & \text { Recycle Waste Stream } \\ \text { SAS: } & \text { Steam Atomized Scrubber } \\ \text { SCR: } & \text { Silicon Controlled Rectifier } \\ \text { SEM: } & \text { Scanning Electron Microscopy/Microscope } \\ \text { SME: } & \text { Slurry Mix Evaporator } \\ \text { SRAT: } & \text { Sludge Receipt and Adjustment Tank } \\ \text { SRS: } & \text { Savannah River Site } \\ \text { SRTC: } & \text { Savannah River Technology Center } \\ \text { TEM: } & \text { Transmission Electron Microscopy/Microscope } \\ \text { TVF: } & \text { Tokai Vitrification Facility (Japan) } \\ \text { WAK: } & \text { Waste from the Karlsruhe Reprocessing Plant } \\ \text { WHC: } & \text { Westinghouse Hanford Company } \\ \text { WSRC: } & \text { Westinghouse Savannah River Company } \\ \text { WVDP: } & \text { West Valley Demonstration Project } \\ \text { XRD: } & \text { X-Ray Diffraction } \\ \text { XRF: } & \text { X-Ray Fluorescence } \\ & \end{array}$


INFORMATION ONLY

-viii- 


\subsection{Summary and Recommendations}

Numerous governments worldwide have committed to stabilization of high level nuclear waste by vitrification. Many of the facilities use (or will use when completed) the Jouleheated ceramic melter as the means of stabilizing the high-level nuclear waste in a glass matrix. These facilities include the German PAMELA in Mol, Belgium, the Tokai Vitrification Facility (TVF) in Tokai, Japan, the Defense Waste Processing Facility (DWPF) in Aiken, SC, the West Valley Demonstration Project (WVDP) in West Valley, NY, and the planned Hanford Waste Vitrification Plant (HWVP) in Richland, WA.

The PAMELA facility began operation in 1985 . The TVF began radioactive operations in 1995. The DWPF began radioactive operations in March,1996 and has filled more than 200 canisters. The WVDP began operations in July, 1996. The HWVP is in the planning stage.

The noble metals are defined as silver, gold, platinum and the platinum group metals: ruthenium, rhodium, palladium, osmium, and iridium. They are called noble because of their resistance to oxidation in contrast to base metals that oxidize when heated in air. They are easily reduced and all occur naturally in their elemental form. Of these, however, only ruthenium, rhodium, palladium, and silver are found in high-level waste as the products of fission reactions. (Note that most of the silver present in the SRS defense waste is from silver saddles used in iodine strippers). They are of concern because the metals and $\mathrm{RuO}_{2}$ are dense and electrically conductive. They tend to settle to the bottom of melters causing disruption of normal melter electrical currents.

A production-scale melter represents a significant capital investment. Replacement, facility downtime, decommissioning, storage, and melter disposal costs can also be major expenses if production melters become inoperable. It is thus very obvious that the overall lifetime of a production melter should be extended to as long as possible. Almost all of the major production and research vitrification facilities have experienced operational problems which can be traced to the presence of noble metals in the melter. These effects were discovered after the design of the existing DWPF melter. Thus the DWPF melter may be more susceptible to these effects than later melters which attempted to mitigate noble metals electrical effects. These metals and their alloys and compounds have tended to settle to the floor of Joule-heated ceramic melters. An accumulation of these dense, conductive and highly viscous materials can adversely affect the melter operation by decreasing the power release in the bulk glass in the melter thereby decreasing the feed throughput capacity and the ability to maintain operating temperatures. This layer can also cause non-uniform and uncontrollable current distributions at the surface of the electrodes which can lead to physical damage or failure of the electrodes. Over time, with the accumulation of these conductive compounds, some melters have suffered a loss of power release so severe that nominal melter temperatures $\left(>1100^{\circ} \mathrm{C}\right)$ could not be maintained. The resulting viscous layer could 
also make the draining of the DWPF melter more difficult, but German and Japanese bottom drain configurations have demonstrated an ability to operate under these conditions.

Several large scale melter demonstrations have been conducted in support of the development of the DWPF melter. While some of these operations have included noble metals (mainly $\mathrm{Ru}$ ) in the slurry feed composition, earlier tests omitted at least one of the following: noble metals in their anticipated chemical forms, potential alloying elements, lead, mercury, or the expected reference combination of reducing and oxidizing agents. Further, previous melter demonstrations with noble metals have not had electrodes similar in geometry to those of the DWPF melter and have therefore not been able to model accurately or predict the electrical response of the DWPF melter to noble metal deposition.

The Integrated DWPF Melter System (IDMS) was designed and constructed to provide an engineering-scale representation of the DWPF melter and its associated feed preparation and off-gas treatment systems. The facility is the first engineering-scale melter system capable of processing mercury and flowsheet levels of halides and sulfates. The IDMS melter also provides meaningful data for predicting the behavior and effects of the noble metals in the DWPF melter.

In order to characterize the behavior of noble metals, 16 runs, using four types of waste sludge simulants containing noble metals have been conducted in the IDMS facility. The sludge simulations were: (1) three runs using a Blend (BL) sludge (a mix of HM and PUREX sludges), (2) four runs using an HM (high noble metals, high aluminum, high viscosity) sludge, (3) seven runs using a PUREX (high iron, low viscosity) sludge, and (4) two runs using the Hanford NCAW sludge.

Specific objectives of this task as defined in the Technical Task Plan[1] pertaining to melter operation were to:

1) demonstrate the long term effects of noble metals on the operating performance of a DWPF-type melter.

2) determine the noble metals material balance around the melter system.

3) determine the chemical form of noble metals in the glass.

4) determine the particle size of noble metals and/or noble metal alloys in the glass.

During the first two runs (BL1, BL2), hydrogen was measured as a feed preparation offgas product. The hydrogen was produced by the noble metal-catalyzed destruction of formic acid during the initial chemical treatment of the sludge simulant. Because of the safety concerns associated with the evolution of hydrogen, the facility was idled while safetyrelated modifications were made to the feed preparation and process vessel vent system. 
The next series of runs (BL3, HM1) were conducted without noble metals or mercury present in the waste sludge simulant. These runs were conducted in order to evaluate the amount of hydrogen which the DWPF could expect during cold simulant testing (which would contain neither noble metals nor mercury).

Following the cold run demonstrations, four runs (HM2, HM3, PX1, PX2) were conducted with HM levels of noble metals (but no mercury). These runs were conducted in order to predict the maximum hydrogen that the DWPF could expect during radioactive operations. It was after these runs that melter floor samples first showed an accumulation of noble metals (mainly $\mathrm{RuO}_{2}$ ). The melter also first showed an electrical response to this accumulation during these runs.

Following these runs, two operations (HWVP1, HWVP2) were conducted in support of the design and operation of the Hanford Waste Vitrification Plant. These runs were conducted with a Neutralized Current Acid Waste (NCAW) simulant and contained maximum predicted levels of noble metals (concentrations similar to HM sludge) for that waste. This waste also contained cadmium which is easily reduced to the elemental form.

The next series of runs (HM4, PX3, PX4, PX5, PX6) were conducted to support the adoption of the Nitric Acid Flowsheet coupled with the Late Wash Precipitate Hydrolysis process. These runs contained HM levels of mercury and of noble metals (highest expected for DWPF feed).

Samples have been taken from the melter floor since the introduction of the noble metals. With increasing amounts of noble metals fed to the melter, there has been a corresponding increase in the amount of noble metals, noble metal compounds, and spinels found on the melter floor. Samples taken at the center of the melter and on the outside of the floor diameter (at the face of one of the electrodes) suggest a non-uniform layer of noble metals and $\mathrm{Ru} / \mathrm{Rh} / \mathrm{Ni} / \mathrm{Fe} / \mathrm{Cr}$ spinels has accumulated. Analysis of these samples revealed a higher concentration of $\mathrm{RuO}_{2}$ in the samples taken from the outside edges of the melt pool. This suggests that the convective currents in the melter tend to "push" the $\mathrm{RuO}_{2}$ from the center of the melter (where it enters) to the outside edges. Melter convection currents tend to be downward at the walls away from the electrodes. Samples taken from the center have normally contained $\mathrm{Ru}$ and $\mathrm{Rh}$ oxides and large amounts of spinels while samples taken from the outer edge have contained fewer spinels, metallic Pd and Pd tellurides, $\mathrm{Ru}$ and $\mathrm{Rh}$ oxides, and $\mathrm{RuS}_{2}$. The presence of the RuS 2 suggests that the temperature at the outer edge may be much lower than that of the bulk melt since this compound decomposes at temperatures $>$ $1000^{\circ} \mathrm{C}$. Material balances of these components show a tendency for the noble metals to be retained as $\mathrm{Ru}>\mathrm{Rh} \gg \mathrm{Pd}$ and $\mathrm{Ag}$. It is estimated that the overall percent accumulations in the IDMS for the noble metals during these runs are $35 \%$ for $\mathrm{Ru}, 21 \%$ for $\mathrm{Rh}$, and close to zero percent for $\mathrm{Pd}$ and $\mathrm{Ag}$. 
In the Research Scale Melter (RSM) studies at PNNL, results suggested that there was a significant nonlinear increase in the amount of noble metal compounds deposited on the melter floor with a 2-fold increase in the nominal noble metal content of the NCAW melter feed simulant. This resulted in a 9-fold increase in the fraction of noble metals that settled.

Noble metal settling is particularly obvious during melter idling (not feeding or pouring). The characteristic settling time seems to be reached between 10 and 20 days of idle time. Approximately $70 \%$ of the $\mathrm{Ru}$ in the melter at the start of an idling period will settle during this critical settling time period. Ruthenium settling data taken within 20 days (of idling) was used to generate a least-squares relationship for relative $\mathrm{Ru}$ concentration in the glass being poured versus idle time for the IDMS melter. The linear region is described by:

$$
\frac{[\mathrm{Ru}]_{\mathrm{t}}}{[\mathrm{Ru}]_{0}}=0.9814-0.04713 \mathrm{t} \quad \text { where } \mathrm{t} \text { is idle time in days }
$$

The ultimate relative concentration appears to be between 0.25 and 0.30 indicating that approximately 25 to $30 \%$ of the $\mathrm{Ru}$ in the melter is of a size or shape that does not settle easily.

As more noble metals were fed to the IDMS melter the upper-to-lower resistivity ratio increased, and therefore current requirement for the bottom electrode pair to maintain the desired melt pool temperature increased as well. Initially a current of $450 \mathrm{amps}$ was necessary to maintain a lower glass pool temperature of $1125^{\circ} \mathrm{C}$. At the end of the melter testing, 650 amps were required to maintain a temperature of $1070^{\circ} \mathrm{C}$. However, the melter did continue to operate with acceptable performance. There was no decrease in the production capacity of the IDMS melter during the tests. A subsequent inspection of the IDMS melter showed that the bottom electrodes had sustained appreciable damage on their lower portions. This damage was probably due to a high current density caused by noble metals partially shorting out the melter. Globules of noble metals were found at the bottom of the melter.

Since the IDMS melter continued to operate in spite of damage, it is difficult to predict the maximum lifetime of the DWPF melter based on the operational experience of the IDMS melter. However, assuming the DWPF melter will withstand the same conditions to which the IDMS melter has been exposed, estimates of the minimum lifetime have been made.

There are several caveats which should be considered when interpreting these estimations. Firstly, the IDMS melter was subjected to numerous idling periods in excess of 20 days. As stated above, approximately $70 \%$ of the noble metals in the melter will settle to the floor during this short idling period. 
IDMS Production

1 IDMS glass with HM or NCAW Noble Metals

2- IDMS glass with Blend Noble Metals

3- Max IDMS glass capacity

4- Number of melter HM turnovers (1/3)

5 - Number of melter Blend turnovers (2/3)

Equivalent DWPF Production

6- Max DWPF glass capacity

7- 38 DWPF Melter turnovers (6 $\times 38$ turnovers)

8- DWPF Melter turnovers ( $6 \times 8$ turnovers)

9- DWPF $100 \%$ production rate

10- Target minimum nominal operạting time,

2 years@70\%

11- Nominal melter turnovers in 511 days

Equivalent DWPF HM Operating Time

12- Hm sludge Ru content

13- Equivalent $\mathrm{HM}$ operating time $((7 / 9) / 24 \mathrm{hrs}$ per day $)$

Equivalent DWPF Blend Operating Time

14- Blend sludge Ru content

15- Equivalent Blend operating time $((8 / 9) / 24 \mathrm{hrs}$ per day $)$

Equivalent Combined Blend Operating Time

16- Equivalent combined Blend operating time $(13+15)$

$40,300 \mathrm{lbs}$

$8,346 \mathrm{lbs}$

$1,063 \mathrm{lbs}$

38 turnovers

8 turnovers

$13,136 \mathrm{lbs}$

$499,168 \mathrm{lbs}$

$105,088 \mathrm{lbs}$

$228 \mathrm{lbs} / \mathrm{hr}$

511 days

213 turnovers

$0.217 w t \%$

91 days

$0.100 \mathrm{wt} \%$

19 days

110 days

Equivalent Combined Tank 51 Operating Time

17- Tank 51 Ru content [30]

$0.005 \mathrm{wt} \%$

18- Equiv. Tank 51 operating time $(((12 \times 13)+(14 \times 15)) / 17)$

4,329 days

NOTE: bold numbers in calculations shown [as given in ()'s] show line items used

Recommendation: Based on IDMS data, the settling of the noble metals appears to be much less during periods of feeding and pouring. This impact, however, may be less in the DWPF Melter due to its larger inner diameter. Therefore, the DWPF should avoid periods of idling when operating with melter feeds containing noble metals. A few extended outages appear preferable to several short period outages; thus when outages must be scheduled, for maintenance, etc., all necessary work should be completed within the extended outage in order to avoid short term outages later.

Secondly, this estimation assumes that the noble metals settle linearly with concentration. This is most likely not the case. In tests conducted at PNNL, it was observed that the settling of the noble metals increased nonlinearly with a 2 -fold increase in the noble metal content over the nominal NCAW levels. Therefore, the amount of noble metals settling to the floor while feeding "Blend" melter feed will be much higher than that seen with the existing Tank 
51 batch la sludge. Still more rapid changes can be expected if HM sludge noble metal concentrations are fed to the DWPF.

The first DWPF melter has not experienced any operational problems associated with noble metals deposition to date. However, because of uncertainties in the blending of Tank Farm wastes, it is difficult to predict a minimum lifetime for subsequent sludge batches.

Recommendation: Tank Farm blending strategies should consider the content of the noble metals in the respective waste tanks. The wastes could be blended such that the noble metal contents are evenly distributed and have a content no greater than that predicted for "Blend-type" sludge (Ru about 0.1 wt\% of the dried sludge solids to the DWPF). This is advantageous not only in the maximization of the DWPF melter life but also in minimizing hydrogen production in the Chemical Processing Cell (CPC). Alternatively, delaying operations with high concentrations of noble metals (HM sludge) to outlying years until possible modifications can be made to subsequent DWPF melters to make them less susceptible to noble metals deposition problems could be done as well.

An inspection of the IDMS melter after shutdown showed that the bottom electrodes had sustained appreciable damage on their lower portions. The Inconel $690 \AA$ drain valve and pipe also had extensive corrosion damage. This damage was probably due to a high current density caused by noble metals partially shorting out the melter.

Recommendation: The bottom electrodes of the IDMS melter should be removed from the melter and characterized for change in dimensions and mode of metallurgical attack. Samples previously removed from the bottom of the melter should be measured for viscosity and electrical conductivity. Any deposits remaining under the electrodes should be removed for physical characterization (viscosity, electrical conductivity) and chemical composition.

The ratio of upper-to-lower glass pool resistance has proved to be an effective measure in indicating the accumulation of noble metals on the floor of the IDMS melter. This ratio continue to rise during the noble metals runs, thereby showing that the bottom electrode circuit resistance was being lowered. This implied that a conductive layer of material (noble metals) was forming on the melter bottom. The post shutdown inspection of the melter showed this was indeed the case.

Recommendation: The DWPF should monitor this ratio as an indication of a conductive accumulation on the DWPF melter floor. The individual circuit resistances should also be routinely monitored and trended with time. When feeds with higher noble metals concentrations are used estimates of noble metals settling should be trended. When noble metals accumulations approach $1-2 \mathrm{~kg} / \mathrm{ft}$ of melter bottom, electrical disruption and electrode attack may occur. 
Although there is an obvious trend of international vitrification facilities to move toward sloped bottom melters, this is not necessarily a viable solution for the DWPF should problems develop. Firstly, the technical time and capital invested in the melt cell does not easily allow radical changes in the present melter design. A sloped bottom melter would require a redesign of the drain valve. Fortunately, melter design and testing in Germany and Japan has proceeded to include reliable drain valves that can function with noble metals. Other facilities have moved to sloped bottom melters. The smallest deviation from existing DWPF design and operating practice which appears technically feasible is a combination of 1) a bottom drain assembly of the German or Japanese type, which have been demonstrated to work with noble metals, 2) mechanical removal of melter bottom deposits after melter draining and cooling, and 3 ) raising and reshaping the bottom electrodes to minimize local current densities.

One modification to the DWPF melter which could be accommodated is the raising of the lower electrodes. It is not known what effect this would have on the operation of the melter with or without a conductive bottom layer. Mathematical models, however, do exist which can be used to predict the effects of such as modification.

Recommendation: Finite element mathematical models should be used to predict the effects of a modified electrode configuration in the DWPF melter.

The West Valley Demonstration melter is designed to be less susceptible to noble metals than the DWPF (which was designed in 1983). The WVDP modifications appear to have been partially successful, yet two-thirds of the electrical resistance in the WVDP melter circuits have been lost after one year of operation with noble metals concentrations comparable to SRS HM waste. WVDP is actively following the electrical response of its melter.

Recommendation: DWPF and SRTC should actively participate in the work at WVDP concerning the electrical response of the WVDP melter, as well as follow their approach to dealing with these issues, which includes the following activities:

- trending of historical operating data;

- updating a computer model for use as a tool in predicting future melter performance, including power needs;

- remote sampling of deposits;

- remote probing the deposits to determine their location and depth; and

- developing remote tools to dislodge deposits of noble metals in situ and performing associated mockups, as applicable. 
- This page left intentionally blank - 


\subsection{Introduction}

\subsection{The Noble Metals}

The Noble Metals are defined as gold, silver, platinum, and the platinum group metals (ruthenium, rhodium, osmium, iridium, and palladium). Figure 1 shows the position of the noble metals on the Periodic Chart. They are called noble because of their resistance to oxidation as compared to base metals that oxidize when heated in air. The noble metals are easily reduced and all occur naturally in their elemental form (usually alloyed with one or more other platinum metals or in gold or silver deposits). However, only ruthenium, rhodium, palladium, and silver are found in high level waste as the products of fission reactions. A brief summary of the chemistry of each of these fission-product noble metals is given below.

\begin{tabular}{|c|c|c|c|c|c|}
\hline $\begin{array}{c}25 \\
\text { Mn } \\
55.9380\end{array}$ & $\begin{array}{c}26 \\
F \theta \\
55.847\end{array}$ & $\begin{array}{c}27 \\
\text { Co } \\
58.9332\end{array}$ & $\begin{array}{c}28 \\
\mathrm{Ni} \\
58.71\end{array}$ & $\begin{array}{c}29 \\
\mathrm{Cu} \\
63.546\end{array}$ & $\begin{array}{c}30 \\
\mathrm{Zn} \\
65.38\end{array}$ \\
\hline $\begin{array}{c}43 \\
\text { TC } \\
98.906\end{array}$ & 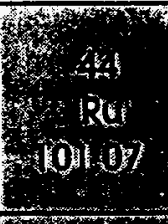 & 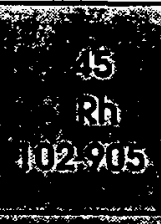 & 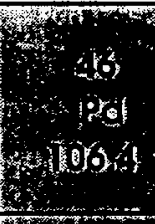 & 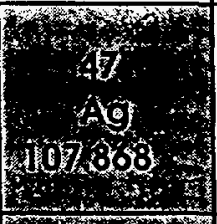 & $\begin{array}{c}48 \\
\text { Cd } \\
112.40\end{array}$ \\
\hline $\begin{array}{c}75 \\
R \theta \\
186.2\end{array}$ & $\begin{array}{c}\text { os } \\
\text { ops } \\
\text { apd }\end{array}$ & $\frac{77}{11}$ & $\left(\begin{array}{c}60 \\
0 \\
0609\end{array}\right.$ & $\begin{array}{c}70 \\
100 \% 96 \%\end{array}$ & $\begin{array}{c}80 \\
\mathrm{Hg} \\
200.59\end{array}$ \\
\hline
\end{tabular}

Figure 1. The Noble Metals

Ruthenium, atomic number 44 , is a very rare.iron-gray metal with an abundance in the earth's crust near $0.0004 \mathrm{ppm}$. Ruthenium possesses several interesting chemical features. Firstly, it may assume a wide number of oxidation states (from 0 to +8 are possible). Secondly, it has a tendency, particularly when in the tetravalent state, to form polynuclear complexes with oxide, nitride or hydroxy bridges. And lastly, ruthenium forms more nitrosyl complexes than any other metal.[2] A hydroxynitroyl form is considered to be typical of SRS wastes.

Of its wide number of oxidation states, $\mathrm{Ru}^{+3}$ and $\mathrm{Ru}^{+4}$ are the mostly likely. In borosilicate glass, the most likely form of ruthenium is $\mathrm{RuO}_{2}{ }^{[3]}$, though, in very reducing conditions, $\mathrm{Ru}$ metal can be formed; while at very oxidizing conditions $\mathrm{RuO4}$, an unstable toxic gas, may be formed. $\mathrm{RuO}_{2}$ is essentially insoluble within the borosilicate glass matrix, even if oxidized. 
The electrical conductivity of $\mathrm{RuO}_{2}$ is comparable to that of the metal at the melter operating temperatures.

Rhodium, atomic number 45 , is a very rare silvery-white metal with an abundance in the earth's crust of $<0.0004 \mathrm{ppm}$. Rhodium exhibits far fewer oxidation states than ruthenium. Almost all of its complexes involve either the tri- or monovalent states. In its general chemistry, however, rhodium resembles ruthenium much more than cobalt.

Palladium, atomic number 46 , is a silvery-white metal and is much more abundant than either ruthenium or rhodium. Palladium is the only one of the platinum metals that is attacked by nitric acid. Metallic palladium has the unusual ability to absorb hydrogen.[2] The most common oxidation state of palladium is +2 . Palladium is slightly soluble in borosilicate glass and is normally present as $\mathrm{Pd}$ metal, $\mathrm{PdO}$, and alloyed with tellurium.

Silver, atomic number 47 , is a white metal which is used in jewelry, dentistry, coinage, etc. Most of the silver present in SRS defense waste is the result of the disposal of silver saddles which have been used to scrub radioactive iodine from process stacks. Silver oxide, Ag2O, is very soluble in borosilicate glass.

Tellurium and selenium, atomic numbers 52 and 34 respectively, are Group VIa nonmetals similar in chemistry to sulfur. They are only slightly conductive and have low melting points and so they, alone, pose no threat to the melter operation. However, they have a strong tendency to react or alloy with the noble metals (esp. with Pd). Thus their chemistry and physical properties are of interest.

Table 1 shows selected properties[4] for each of these platinum metals as well as for silver and the alloying agents tellurium and selenium. 
Table 1. Chemical and Physical Properties of the Noble Metal Properties

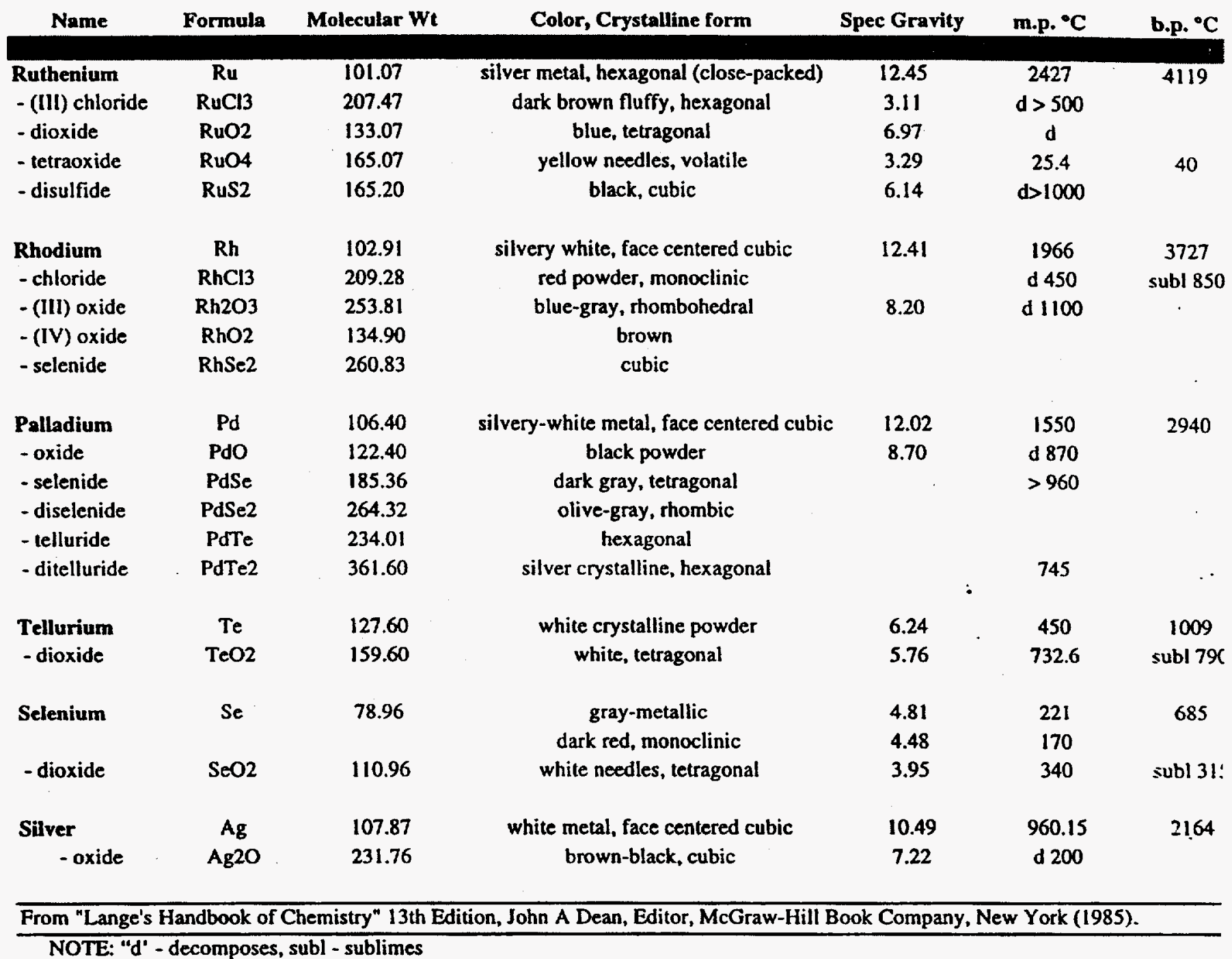

\subsection{Background (International Experience)}

The high level nuclear wastes of the United States are quite different from those of other countries. The nuclear wastes which the US is vitrifying are mainly those resulting from the production of nuclear materials for defense purposes. The high level waste in other countries (Federal Republic of Germany, Japan, etc.) have resulted from the reprocessing of commercial nuclear fuel (from power reactors). Because of the differences in the waste origins, the expected levels of noble metals in the wastes are also varied. Table 2 shows a comparison of noble metals concentrations for selected German, Japanese, and American wastes. These tests were conducted after the design of the DWPF melter, thus the benefits of these studies have not been incorporated to minimize noble metals effects of DWPF melter operations. 
Table 2. Noble Metals in German, Japanese, and American Waste Glasses*

\begin{tabular}{ccccc} 
Component & $\begin{array}{c}\text { PAMELA } \\
\text { LEWC/WAK }\end{array}$ & $\begin{array}{c}\text { TVF } \\
\text { LLASS }\end{array}$ & $\begin{array}{c}\text { SRS/DWPF } \\
\text { HM/BLEND }\end{array}$ & $\begin{array}{c}\text { HWVP } \\
\text { NCAW'91 }\end{array}$ \\
\cline { 2 - 5 } $\mathrm{Ru}$ & $1000 / 5100$ & 5530 & $830 / 350$ & 870 \\
$\mathrm{Pd}$ & $? / 3000$ & 2960 & $310 / 160$ & 300 \\
$\mathrm{Rh}$ & $? / 1400$ & 1290 & $150 / 68$ & 240 \\
$\mathrm{Ag}$ & trace & 93 & $20 / 77$ & 320 \\
Total & $? / 9500$ & $\overline{9873}$ & $\overline{1310 / 655}$ & $\overline{1730}$
\end{tabular}

* Values in ppm elemental projected in the glass product

** LEWC $=$ Low Enrichment Waste Concentrate

WAK = waste presently stored at the Karlsruhe Reprocessing Plant (Note: the present plans are for this waste to be vitrified at Karlsruhe)

As one can see in this Table, the noble metal content of the commercial waste (the Japanese TVF and the German WAK) is considerably higher than that of the defense wastes (SRS HM and Blend, and the Hanford NCAW). However, as will be explained later, the flat-bottomed PAMELA melter experienced major operational problems which were linked directly to the deposition of noble metals and their compounds while processing the LEWC material. The LEWC material contains a total noble metal concentration (1360 ppm in the final glass) which is very similar to that of the SRS HM (1310 ppm in the glass) and the HWVP NCAW (1730 ppm in the glass).

A general description of the vitrification programs of several nations is summarized below. In each case, any testing with noble metals is specifically discussed.

\subsubsection{Testing in Japan}

The Japanese Power and Nuclear Fuel Development Corporation (PNC) produced 3.5 tons of simulated waste glass containing $0.74 \% \mathrm{RuO}_{2}, 0.11 \% \mathrm{Rh}, 0.30 \% \mathrm{Pd}$, and $0.02 \% \mathrm{Ag}$. [5,6] The simulant contained no sulfur. The melter feed was an aqueous slurry of borosilicate glass frit and formic acid-denitrated waste. At the end of the test, the electrical field in the flat-bottomed melter was distorted to the point that glass processing could not continue. The deposits on the melter floor were a mixture of $\mathrm{RuO}_{2}$, and alloys of $\mathrm{Pd} / \mathrm{Te}$ and $\mathrm{Ru} / \mathrm{Rh}$. With these results, PNC redesigned their melter to become more noble metals compatible. Small scale tests led to the design and construction of an engineering scale melter capable of handling noble metals. Tests with this engineering scale melter indicated that the melter 
floor required at least a $45^{\circ}$ slope if the deposits are to be collected and tapped off through a bottom drain valve. [7] This design has been incorporated into the TVF full scale melter design. Tests conducted in full scale operations have shown that if the bottom section of the melter (just above the drain) is held at a relatively low temperature $\left(800^{\circ} \mathrm{C}\right)$ until just prior to initiation of draining, the noble metals discharge efficiency is $>99 \%$.[8] This method is probably not suitable for DWPF wastes because the relatively high concentrations of $\mathrm{Cr}, \mathrm{Fe}$, $\mathrm{Ni}$; and $\mathrm{Mn}$ would result in accumulations of devitrification products at these low temperatures. These products would block the drain and be difficult to redissolve. Alternatively, PNC electrical modeling has indicated that raising the electrodes off the bottom of the melter by a distance equal to the radius of the melter will assure adequate melter resistance. Two dimensional modeling of this approach with the DWPF melter geometry is discussed in reference 7 . The TVF $45^{\circ}$ sloped bottom drain melter is shown in Figure 2.

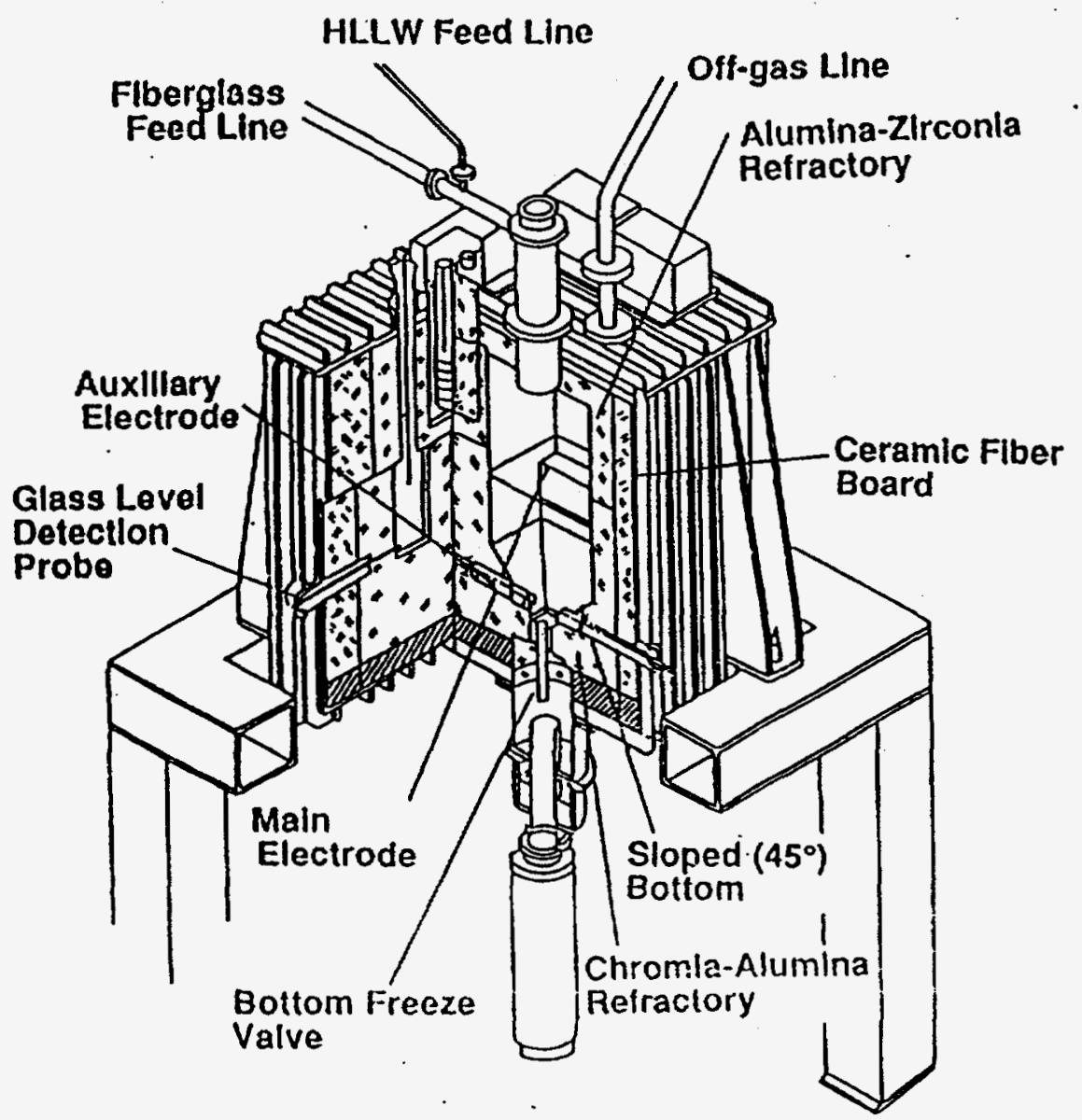

Figure 2. Japanese TVF $45^{\circ}$ Sloped Bottom Melter 


\subsubsection{Testing in the United Kingdom}

Although the British have decided to use the French AVM vitrification technology (inductively heated crucible), they have conducted research with small Joule-heated ceramic melters. During a small scale test, $117 \mathrm{~kg}$ of simulated waste glass containing $0.6 \%$ noble metals was produced by the United Kingdom Atomic Energy Authority (UKAEA).[5] During a 3 month melter idling period the effective melter resistance steadily decreased, until further current increases to maintain temperature became impossible. Melter disassembly and examination indicated that the glass adhering to the bottom $4 \mathrm{~cm}$ of the electrodes contained about $15.8 \% \mathrm{Ru}$. Ru was primarily present as the metal, and associated with tellurium, but some $\mathrm{RuO}_{2}$ was also detected. Metallographic and mechanical examination of the electrode indicate that this same lower $4 \mathrm{~cm}$ region had operated close to the alloy 690 melting point of $1350^{\circ} \mathrm{C}$, and small projections at the melter foot had been partially melted, even though the monitored glass temperatures had never exceeded $1150^{\circ} \mathrm{C}$. It was concluded that a $4 \mathrm{~cm}$ layer of high electrical conductivity glass formed when Ru collected at the melter bottom, and local electrical resistivity dropped as the layer compacted. Low resistance in this area caused power to concentrate at the bottom of the electrodes, resulting in localized overheating due to a high current density, even at low total power.

\subsubsection{Testing in France}

The French AVM vitrification technology uses an inductively heated crucible and therefore is not impacted by noble metals deposition as is the Joule-heated technology.

\subsubsection{Testing in Germany and Belgium (PAMELA)}

Beginning in June, 1985, approximately $47 \mathrm{~m}^{3}$ of Low Enrichment Waste Concentrate (LEWC) containing 1.5 to $2.2 \mathrm{~g} / \mathrm{L}$ noble metals were converted into 78 tons of waste glass using a Kerforschungszentrum Karlsruhe (KfK) designed flat bottom melter in the Deutsche Gesselschaft fur Wiederaufarbeitung von Kernbrennstoffen $m b H$ (DKW) PAMELA facility in Mol, Belgium. [9] This melter is shown in Figure 3.

During operation, some of the melter bottom electrodes suffered severe local corrosion. This localized corrosion was the result of significantly overheating the electrodes with excessive local current densities. Probing of the glass determined that a $5 \mathrm{~cm}$ thick layer of conductive material at the melter floor was the cause of the shorting. Figure 4 shows the distortion of the electrical field by this layer of noble metals. The figure shows a high current flux between the upper and lower electrodes and low power generation in the upper portion of the melter caused by low local current densities. It also shows the low power generation at the bottom of the melter caused by the high current/low resistance path (noble metals layer). 


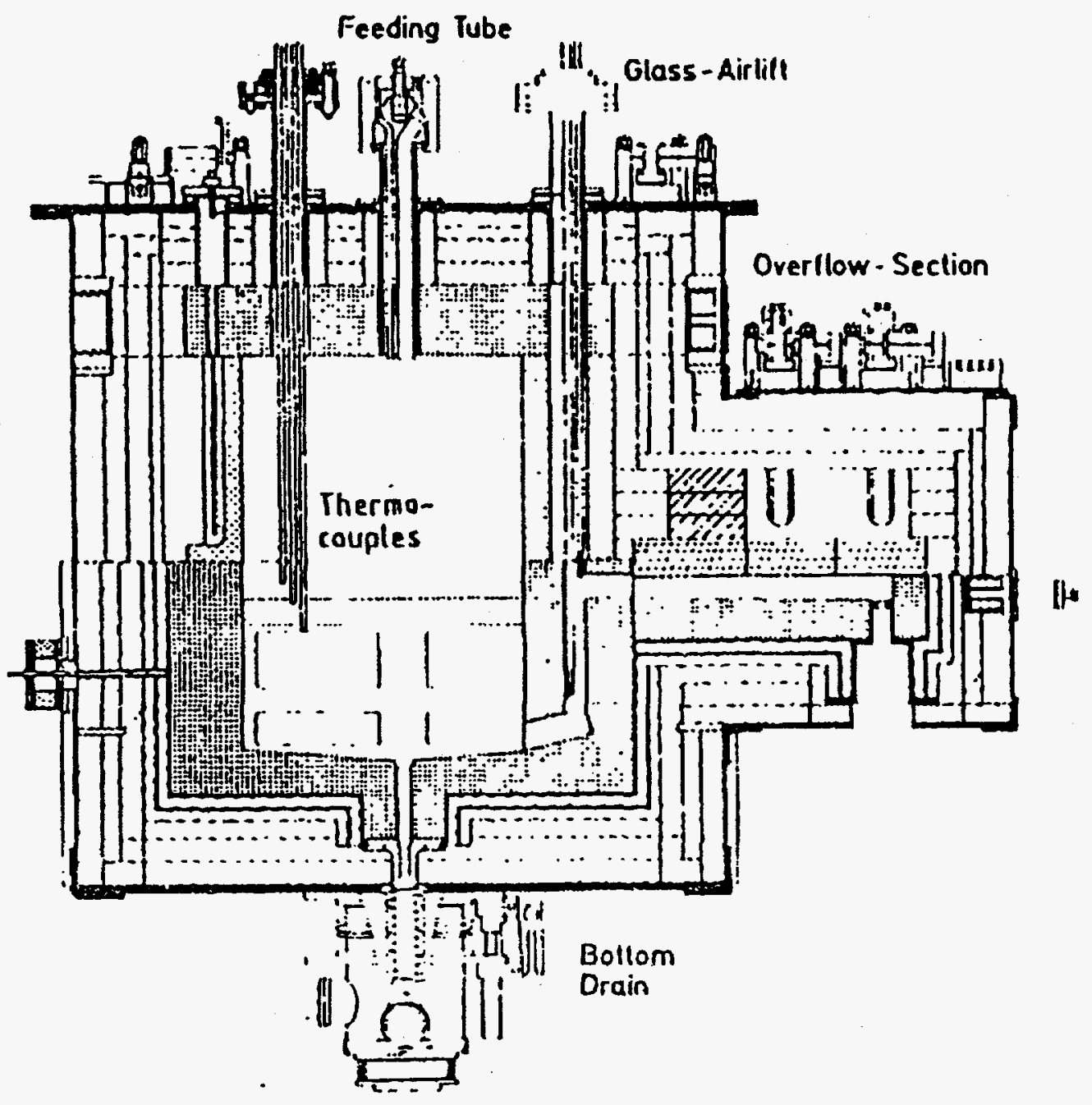

Figure 3. German PAMELA Flat-Bottom Melter

Analysis of samples determined that the deposition on the melter floor was ten times more conductive than the bulk glass and contained $10.4 \% \mathrm{RuO}_{2}, 0.3 \% \mathrm{RhO}_{2}, 0.05 \% \mathrm{PdO}, 0.02 \%$ Se, $0.02 \% \mathrm{Te}$, and $0.25 \% \mathrm{~S}$.[5] Thus, $\mathrm{RuO}_{2}$ is believed to be the major cause of the shorting. Attempts to remove of this viscous layer by routine glass pouring via a bottom drain were not successful. However, sparging of the sludge layer was partially successful in resuspending and flushing the deposits; and, operation of the melter continued at a reduced production rate using other electrodes higher in the glass pool. The melter was ultimately replaced in May 1988 due to a corroded wall section in the riser of the glass overflow system. [9] 
In all, the flat-bottomed PAMELA was operated for almost 3 years and produced 220 tons of radioactive waste glass from $47 \mathrm{~m}^{3}$ of LEWC and $218 \mathrm{~m}^{3}$ of High Enrichment Waste Concentrate (HEWC). Note that the HEWC noble metal content was about 10 times less than that of the LEWC.

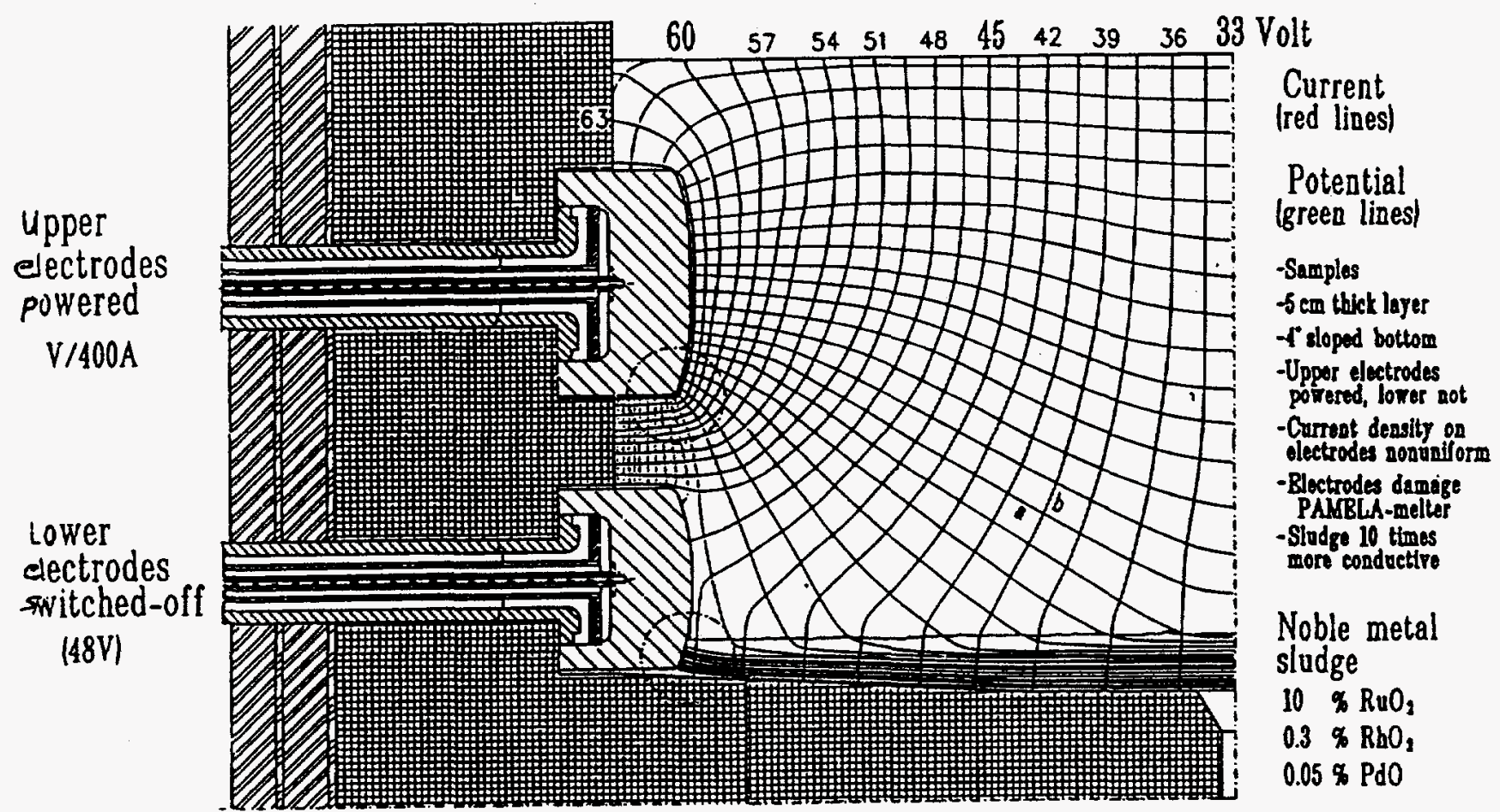

Figure 4. PAMELA Flat-Bottom Melter Showing Distortion of Electrical Field by Noble Metals on Bottom

With the operational problems of the flat-bottomed PAMELA melter, designs for future melters were modified to include noble metals compatibility for wastes from the proposed Wackersdorf Reprocessing Facility (WAK) and were simplified in terms of construction, remote maintenance and decommissioning. [10]

The first technical solution to minimize the effects of noble metal precipitation was the construction of the $\mathrm{K}-\mathrm{W} 245^{\circ}$-sloped bottom melter. This melter is shown in Figure 5 . In tests conducted in a prototype industrial-scale mock up plant, the noble metals discharge efficiency of $25 \%$ in the flat-bottomed melter was increased to about $65 \%$ in the K-W2 melter. Additional air sparging of the glass pool raised the efficiency to $85-90 \%$. These results suggested that the design of a sloped-bottom melter was a step in the right direction to removal of insoluble melt deposits. However, material was found deposited in the melter corners (where the slope is less than $45^{\circ}$ ) so the concept was modified to include steeper side walls and localized sparging at the melter bottom, combined with bottom draining. Figure 6 
shows location of the deposits at the bottom of the melter. They were found in the relatively stagnant corner areas where the sloped walls intersect to form low dihedral angle corners. Table 3 shows the noble metals concentration in samples taken from the deposits from the locations indicated on Figure 6.

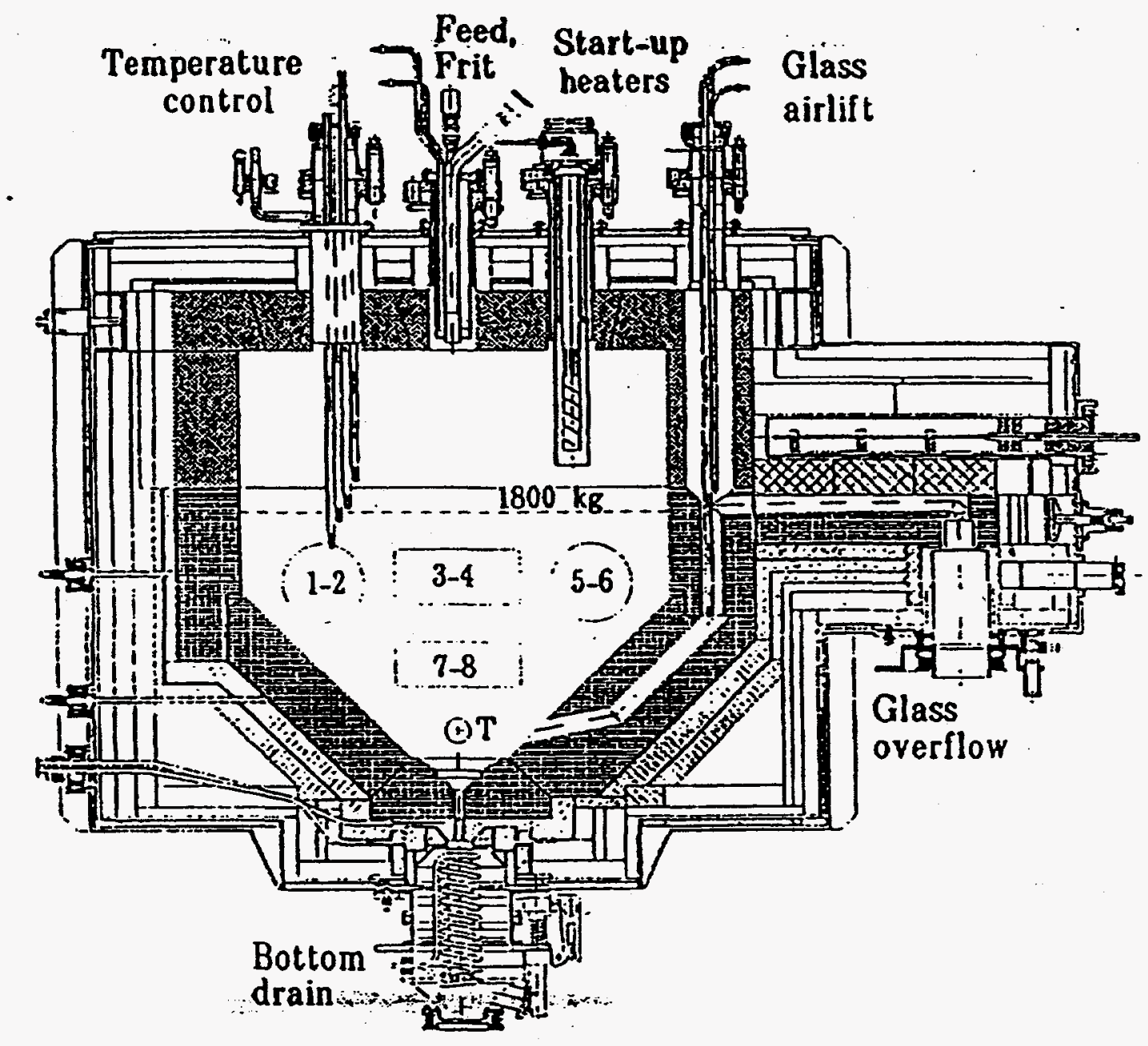

Figure 5. German K-W2 $45^{\circ}$ Sloped-Bottom Melter 

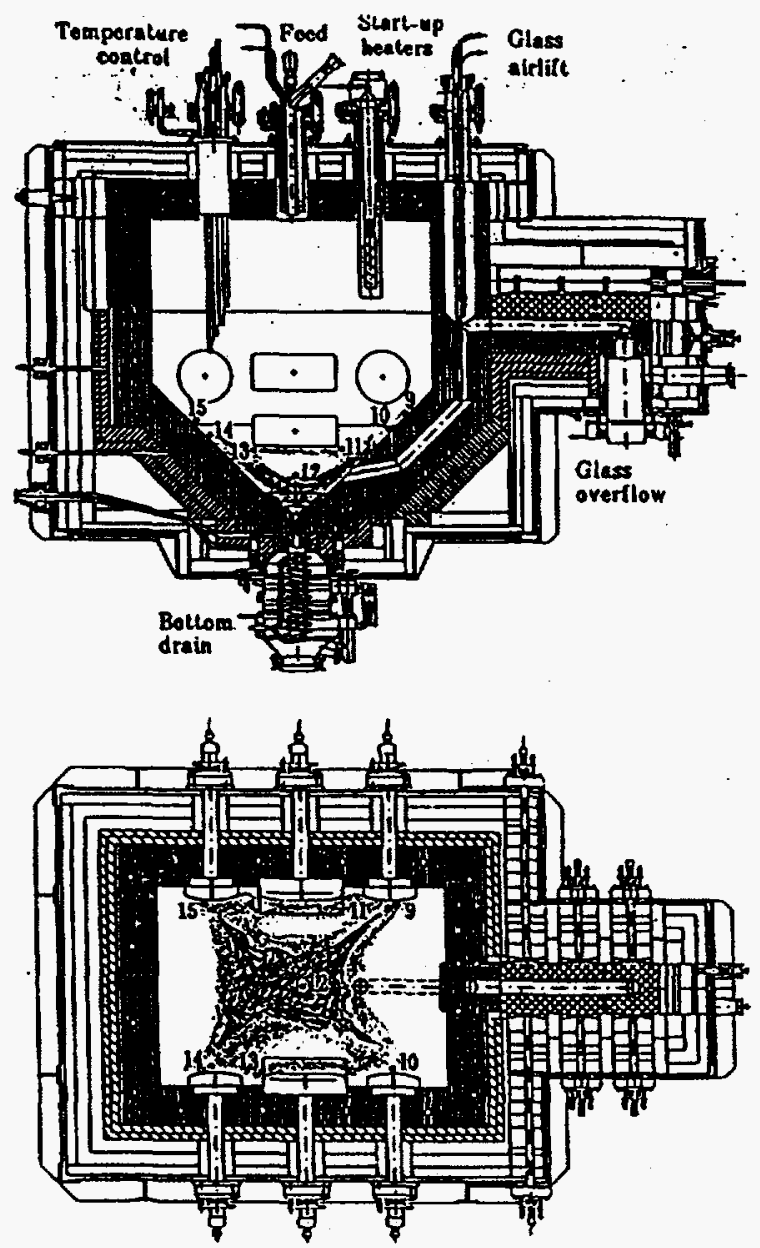

Figure 6. Location of Residue Which Remained in German K-W2 Melter

Table 3. Noble Metals Concentrations in Bottom Residue of German K-W2 Melter

\begin{tabular}{cccc} 
Sample No. & $\mathrm{RuO}_{2}$ & $\begin{array}{c}\text { concentration (wt \%) } \\
\mathrm{Rh}\end{array}$ & $\mathrm{Pd}$ \\
\hline 9 & 12.56 & 0.24 & 6.05 \\
10 & 11.83 & 0.34 & 5.58 \\
11 & 12.13 & 0.50 & 6.45 \\
12 & 12.10 & 0.40 & 5.37 \\
13 & 10.00 & 0.41 & 6.28 \\
14 & 11.47 & 0.42 & 5.35 \\
15 & 11.47 & 0.33 & 5.29 \\
\hline Nominal glass values & 0.69 & 0.122 & 0.452
\end{tabular}


Combining the experiences of the operations of PAMELA and K-W2 melters, the advanced $60^{\circ}$-sloped bottom K-6' melter was designed. This melter is shown in Figure 7. The melter has vertical walls above the main power electrodes. Between the two power electrode sets, the walls are $60^{\circ}$ sloped. The lower part of the melting tank has the function of a settling chamber with $75^{\circ}$ wall inclination. In inactive testing using the $\mathrm{K}-6^{\prime}$ melter, Ru discharge efficiencies were about $90 \%$ for bottom-drained glass pourings but were $<60 \%$ for overflow pourings. [10] The present melter in the PAMELA facility is of a design similar to this K-6' melter.

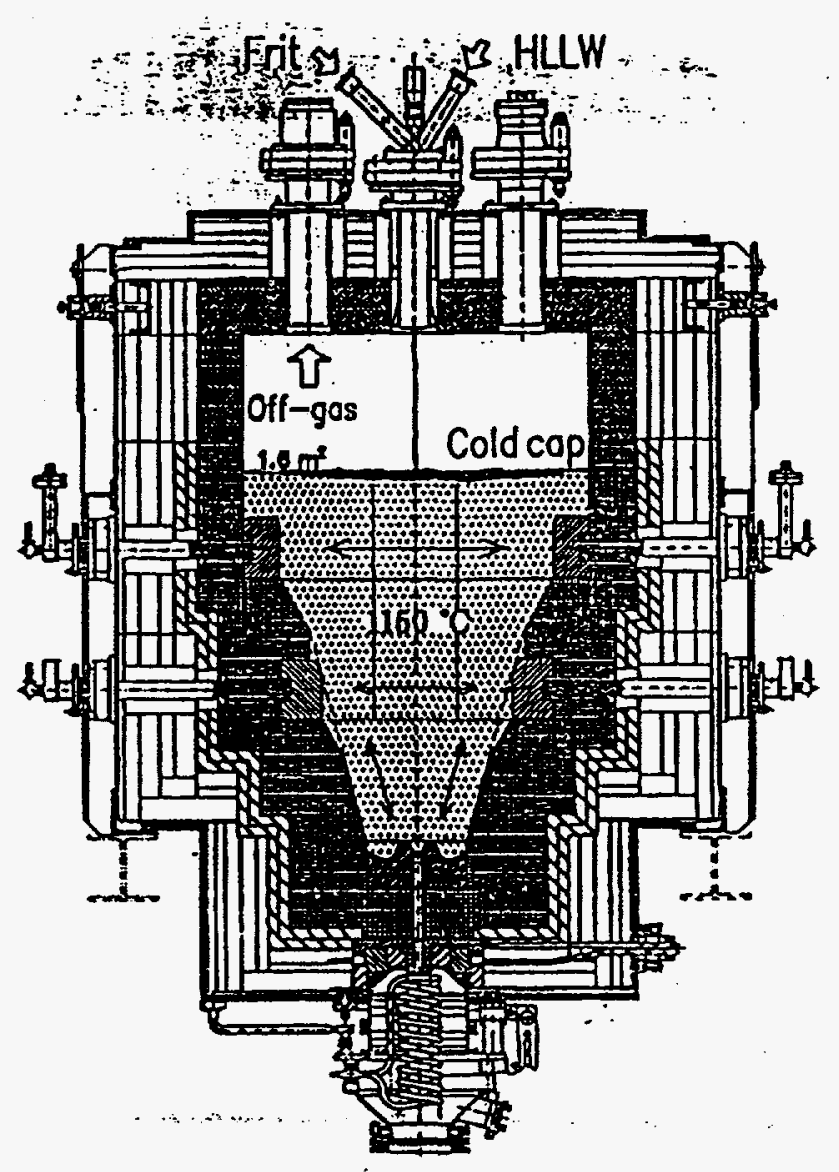

Figure 7. German K-6' $60^{\circ}$ Sloped-Bottom Melter 


\subsection{Background (US Experience)}

\subsubsection{Testing at the Pacific Northwest National Laboratory}

A series of five melting tests were conducted at the Battelle Pacific Northwest National Laboratory (PNNL) with very reducing simulated DWPF melter feeds derived from formate salts. Sulfide nodules from the tank floor at the end of these runs contained $20 \%$ of the ruthenium, $25 \%$ of the selenium, and $40 \%$ of the tellurium fed to the system. The nodule composition was nickel sulfide, $\mathrm{Ni}_{3} \mathrm{~S}_{2}$, with part of the sulfur replaced by selenium and tellurium. A total of about $45 \%$ of the ruthenium fed is believed to have collected at the melter floor, partially as $\mathrm{RuO}_{2}$ particles. In a similar 30 day campaign in an engineering scale melter, ruthenium was added as $\mathrm{RuO}_{2}$, and feed was prepared with mercury and less reducing agent (formic acid). The resulting glass was not strongly reduced, and only small $\mathrm{Ru}$ particles 3 to 6 microns in diameter were found on the melter floor. Analysis of the glass concluded that the majority of the ruthenium had remained as finely dispersed $\mathrm{RuO}_{2}$, and exited the melter with the glass. [5]

More recent testing by PNNL has included the Research Scale Melter (RSM) in which a variety of conditions were modified to understand their effects on the behavior of the noble metals. These included glass oxidation/reduction REDOX state, bulk glass temperature, noble metal concentration, etc. The tests suggested that there is a significant nonlinear increase in the amount of noble metal compounds deposited in the melter with a 2-fold increase in the nominal noble metal content of the NCAW melter feed simulant. [11]

Settled layers of noble metals damaged the electrodes and refractory at the bottom of the RSM. It is not known if this was due to chemical effects or localized heating effects. The lower $1 / 3$ of one of the electrodes was removed by the effect of a noble metal layer only 0.75 to 1.5 inches deep. The localized refractory loss was 0.5 inch. These effects occurred after only 47 days of feeding, with a $45 \%$ loss of resistance across the electrodes. The noble metals were not uniformly deposited. The accumulated noble metals at the conclusion of testing was $1.2 \mathrm{~kg} / \mathrm{sq}$. $\mathrm{ft}$. of melter bottom. It was concluded that the likely mode of attack was that the noble metal layer was effectively electrically connected to one of the electrodes, but with a gap between the layer and the other electrode. The net result was the creation of high current densities in the glass adjacent to the electrode that was not connected to the noble metal layer. Either high localized temperatures, or the resulting high current densities at the face of the electrode caused rapid localized attack of the electrodes and refractory damage. The RSM tests also concluded that when $\mathrm{Fe}(\mathrm{II}) / \mathrm{Fe}$ (total) is greater than 0.25 , then the Ru will be in its metallic state. PNNL concluded that under these reducing conditiohs the $\mathrm{Ru}$ will alloy with the $\mathrm{Rh}$, and increase the rate of noble metal accumulation, thereby shortening the melter life. Mass balances indicated that the accumulation rate is very sensitive to noble metal concentration: At nominal concentrations only $5 \%$ of the noble 
metals which were fed to the melter accumulated on the floor of the melter, but at $2 \mathrm{X}$ nominal concentrations $46 \%$ accumulated. Thus, the tests indicate that a $2 X$ concentration increase can accelerate the noble metal effects by a factor of 9 .

PNNL has also sponsored testing in the Engineering Scale Melter (ESM). This work was performed by personnel at the Institute fur Nuklear Entsorgungstechnik at Kernforshungzentrum Karlsruhe in Karlsruhe, Germany. These tests, which were run at the nominal NCAW noble metal concentrations, resulted in considerable deposition (mainly $\mathrm{RuO}_{2}$ ) on the floor of the $1 / 10$ th scale melter. $[12,13]$

The Engineering Scale Melter was scaled down from DWPF dimensions, with similar electrode configuration and $10 \%$ of the melter surface area of the DWPF melter. The octagonal internal shape closely approximated the DWPF cylindrical configuration. Thus the test was conducted with the best physical simulation of the DWPF available. The final mass balance concluded that $35 \%$ of the Ru, Pd, and $\mathrm{Rh}$ fed to the melter settled to the floor. At the end of the 49 days of tests the resistance to the lower set of electrodes had decreased by 10 to $15 \%$. (IDMS Melter tests required 5 times as much glass processing to produce the same percentage change in electrical resistance, or about 50 melter volumes). At the end of the tests approximately $1.15 \mathrm{~kg} / \mathrm{sq}$. ft. noble metals had accumulated in a layer $0.75-1.2$ inches deep. Noble metals were fed as soluble compounds, equivalent to : $\mathrm{Ru} 0.08 \%, \mathrm{Rh}$ $0.023 \%$, and Pd $0.03 \%$ of the glass. These concentrations are similar to DWPF "HM" waste type glasses, and of the concentrations in Hanford "NCAW" waste glasses.

On the basis of The Research Scale and Engineering Scale Melter Tests, PNNL developed both lumped parameter and finite element models of the electrical effects in the melter. They concluded that the expected operating life of a DWPF melter vitrifying feed similar to DWPF HM material would be about 192 days. This limit is based upon electrode transformer current capacity. Based upon this and other experiments it is probable that significant electrode damage would occur under these conditions: This is very close to the time that the IDMS melter showed electrode damage (216 days equivalent combined operating time for IDMS at Blend levels of noble metals). At the current Tank 51 concentration, the IDMS equivalent combined operating time is 4,329 days, so that lifetimes projected from these Tank 51 noble metals concentrations are not representative of DWPF operations with average noble metals content, or higher HM sludge levels.

\subsubsection{Testing at the Savannah River Site}

Prior to the IDMS melter studies, melting studies were conducted in the SRTC Research Melter (Mini-Melter). In these studies, up to $20 \%$ of the noble metals in the simulated DWPF melter feeds were found to settle on the melter floor. However, the glass produced in these tests was very reducing. Further, the Mini-Melter contained almost no natural convection to keep the insolubles suspended in the melt.[14] 


\subsubsection{Testing at the West Valley Demonstration Project}

At the West Valley Demonstration Project (WVDP), the slurry-fed ceramic melter (SFCM) was in test operation from December 1984 to December 1989 to vitrify simulated nuclear waste slurries. In this study, deposition of insolubles and crystallized species on the SFCM floor during the vitrification process were analyzed. The results indicate that the thickness of the sludge layer on the floor of the SFCM was not more than $6 \mathrm{~cm}$ deep and consisted mostly of $\mathrm{Fe}-\mathrm{Cr}$ spinels, and $\mathrm{RuO}_{2}$ dispersed in a glassy borosilicate matrix. Also, crystalline $\mathrm{Ce}_{2} \mathrm{O}_{3}$ and undissolved phases consisting primarily of alumina and chromia were present in trace amounts but were inhomogeneously distributed in the glassy matrix on the SFCM floor. Greater than $87 \%$ of the $\mathrm{RuO}_{2}$ fed to the melter was flushed out with normal glass pouring. [17] The SFCM was designed prior to the sloped bottom German and Japanese melters (see Figure 8). It has a unique prismoidal shape with sloping walls and a bottom electrode which was intended was intended to minimize noble metals effects.

\section{Plan Section of Refractory}

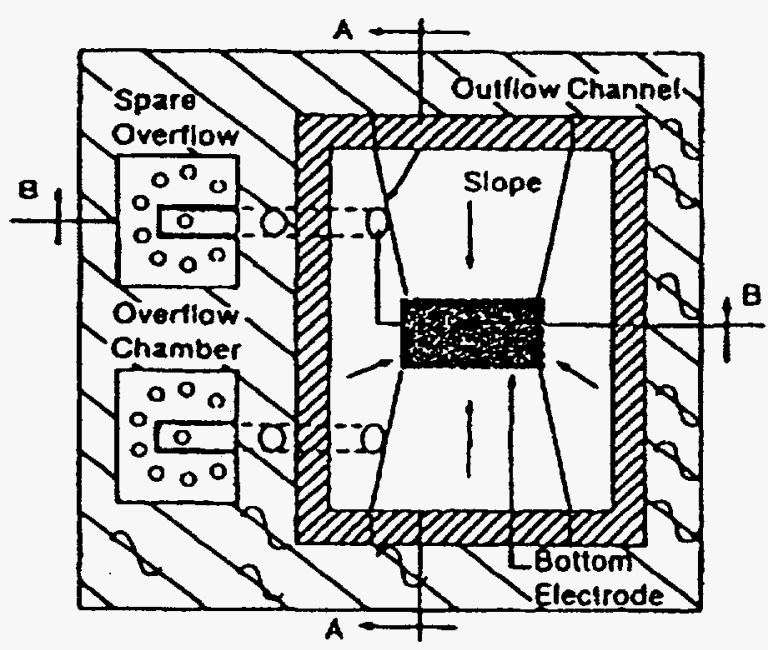

Vertical Section

B-B

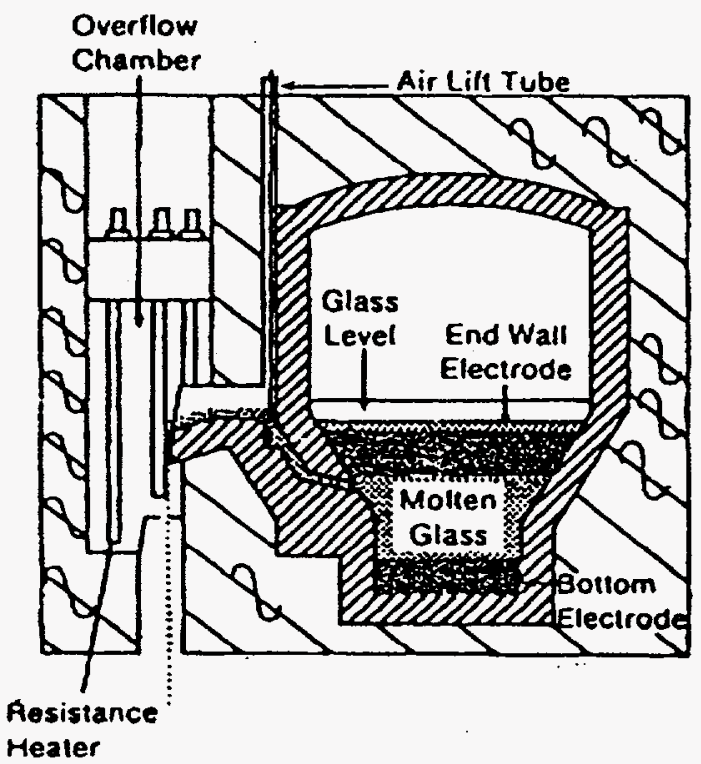

Figure 8. West Valley Slurry Fed Ceramic Melter (SFCM)

Five days of non-radioactive surrogate operations with noble metals were conducted on the WVDP melter before radioactive operations were started. No electrical disturbances were noted during the short test period, but deposits were found on the melter bottom and at the dihedral angle between melter walls, analogous to the German W-4 campaign experience. A preliminary material balance showed that $95 \%$ of the $\mathrm{Ru}$ had been washed out via the overflow drain. 
The expected ruthenium concentration in WVDP radioactive glass is $0.08 \%$ by weight based upon fuel burnup fission product yields. Analyses after start of radioactive operations indicate actual values of 0.06 to $0.15 \%$, and are being reviewed. The expected concentration is very similar to DWPF glass if made from HM sludge. After approximately one year of operation a dramatic change in the electrical resistance of the melter was found (fall of 1997) which required adjustment to current control limits to the melter.

Long term trending of historical data from the WVDP melter indicated a downward trend in the electrical resistance between the melter electrodes and skewing of current towards the bottom electrode (Figure 9). The problem is significant enough that a team of vitrification experts was assembled. Preliminary conclusions from this team are as follows. The downward trend in electrical resistance and the skewing of current towards the bottom electrode are most likely caused by deposits of noble metals. The primary effect caused by the accumulation of noble metals is that more current is needed to maintain the same.power input into the melter. Trending indicates that sufficient current capacity is available to maintain the present glass production rate at least through June 1998. Part of the detailed action plan includes the need for enhanced monitoring and detection capabilities.

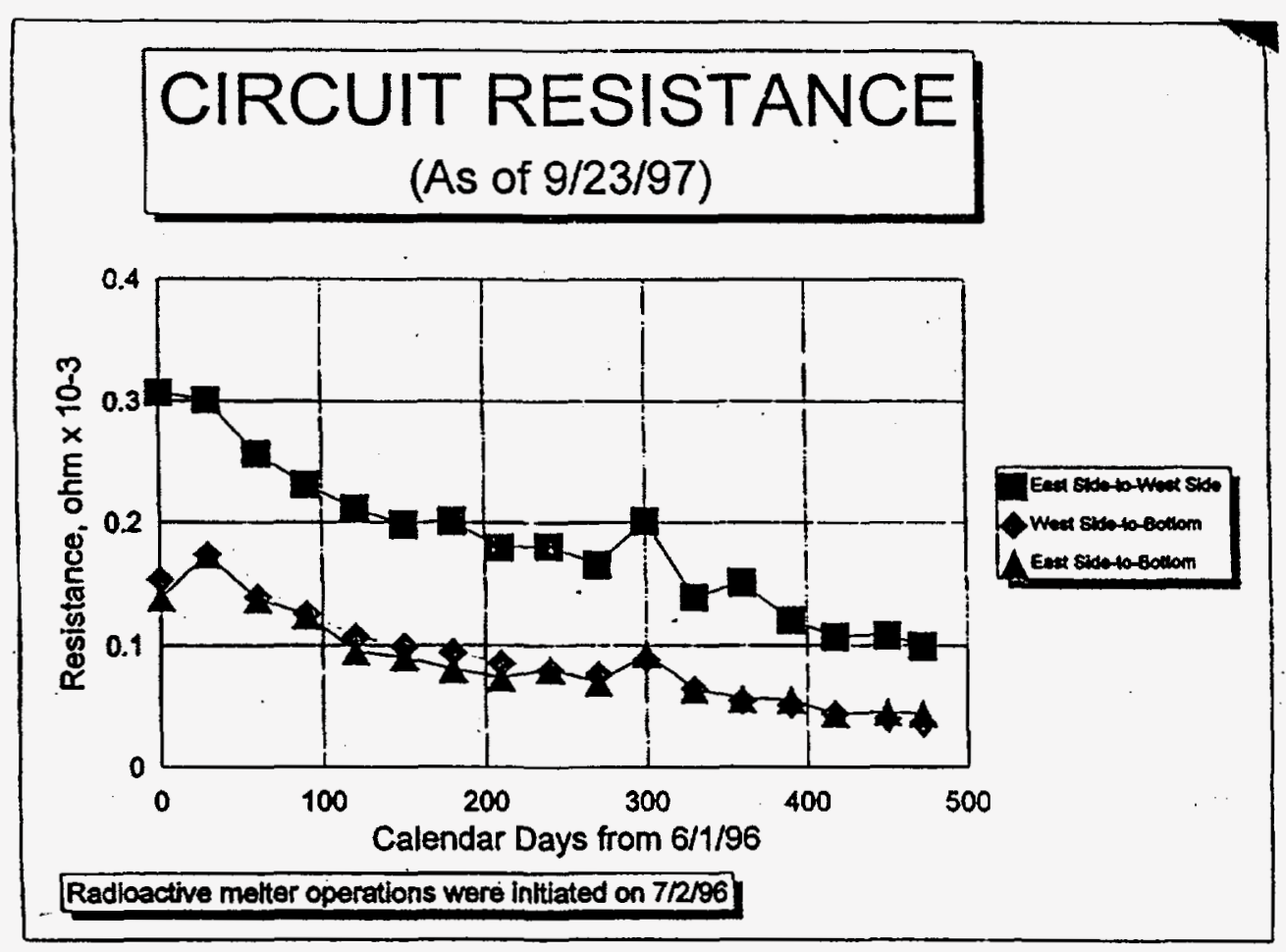

Figure 9. WVDP Melter Circuit Resistance During Radioactive Operations 


\subsubsection{Path Forward for WVDP Noble Metals Concerns}

A team of vitrification experts (assembled by West Valley) gave numerous recommendations for addressing the WVDP noble metals concerns in 1997. They can be summarized as follows:

- assess the adequacy of currently available diagnostic/monitoring capabilities for detecting accumulation of noble metals;

- develop enhanced melter monitoring and detection capabilities with appropriate action limits;

- predict future melter power needs and develop work arounds to meet these needs;

- continue to collect and evaluate data aimed at characterizing the noble metal deposits in the melter;

- develop tools to dislodge the deposits of noble metals in situ;

- develop methods for flushing and draining the melter to remove deposits; and

- develop methods for visually inspecting the melter if it is drained and mechanically dislodging the deposits.

A detailed action plan was developed based on the above which is expected to include the following activities:

- trending of historical operating data;

- updating a computer model for use as a tool in predicting future melter performance, including power needs;

- evaluating alternatives if glass production capacity in the melter become limiting;

- obtaining a sample of the deposits;

- probing the deposits to determine their location and depth;

- developing tools to dislodge deposits of noble metals in situ and performing associated mockups, as applicable;

- following up on initial contacts with international vitrification counterparts; and

- installing a secondary transformer.

These recommendations will be evaluated to determine if they are technically feasible, 'add to the understanding and control of changes in melter performance, and represent an acceptable risk to ongoing vitrification operations. The implementation of these recommendations will be based on the trending of the data, the development of analytical models to predict longterm melter performance and the need to implement any mitigative actions, if required. Therefore, not all of the above recommended actions may be implemented. 


\subsection{IDMS / DWPF System Description}

This section discusses the IDMS and DWPF equipment associated with the feed delivery and melter systems. For description of other IDMS systems (e.g. Feed Preparation, Precipitate Hydrolysis, etc.), consult the referenced report. [17]

\subsection{Feed Delivery System}

The feed delivery system consists of (1) the Melter Feed Tank (MFT), (2) the melter feed pump, and (3) the melter feed line and feed tube.

The DWPF MFT is a 10,000 gallon Hastelloy C-276 flat-bottomed tank with internal Hastelloy C-276 cooling coils. The DWPF MFT has a 100-horsepower Hastelloy C-276 agitator controlled by a variable speed drive (high speed is $100 \mathrm{rpm}$ ). The DWPF MFT agitator has both upper and lower impellers. The upper impeller has three blades of a hydrofoil design while the lower is a four blade flat impeller that acts as a sweeper to keep solids from depositing on the bottom of the tank. The DWPF impellers have a 36-inch diameter.

The IDMS MFT is a 1500 gallon dished-bottom Hastelloy C-276 tank with an internal Hastelloy C-276 cooling coil. Agitation is accomplished via a 15-hp variable speed agitator. The IDMS MFT agitation system is similar to that of the DWPF except the upper impeller of the IDMS MFT agitator is a four blade pitched design with a diameter of 24 inches. During the IDMS Noble Metals testing, the MFT agitator has been operated at a speed such the shear rate matched that of the DWPF MFT. The shear rate is defined as:

$$
\text { s.r. }=\frac{\text { Agitator tip speed }(\mathrm{ft} / \mathrm{sec})}{\text { Distance from tip to vessel }(\mathrm{ft})}
$$

This corresponded to a tip speed of $9.08 \mathrm{ft} / \mathrm{sec}(87 \mathrm{rpm})$.

In both the IDMS and DWPF, a recirculation loop feed system is used. In the DMS, the slurry is recirculated through a 2 -inch pipe using a veinless centrifugal pump which is external to the tank. The loop pressure is applied using a venturi-type restrictor at the return to the tank. The loop pressure forces the slurry through a strainer, a 3-way valve, and 50 feet of 0.25 -inch ID piping to the melter feed tube. The IDMS feed strainer is a plate with nine 0.0082 -inch diameter holes which have a combined cross-sectional area equal to that of the feed line. The flow rate to the melter is measured via a magnetic flow device and is controlled by varying the pump speed.

In the DWPF, the slurry is recirculated through a 2-inch pipe using a vertical centrifugal pump which is internal to the tank. As in the IDMS feed system, the loop pressure in the 
DWPF recirculation line is applied using a venturi-type restrictor at the return to the tank. The loop pressure forces the feed slurry through a strainer and 40 feet of 0.43 -inch line.

The IDMS melter feed tube extends through the melter lid past the lid heaters and discharges the slurry one foot above the melt pool. Slurry is fed through the innermost pipe of the feed tube which has an ID of 0.18 -inch. The slurry feed pipe temperature is maintained at 30 $40^{\circ} \mathrm{C}$ by a cooling water jacket that extends all the way to the feed discharge. Water cooling helps prevent slurry drying and pluggage in the feed tube. The DWPF melter has two feed tubes of approximately 0.43 -inch diameter.

\subsection{Melter System}

The DWPF melter, shown in Figure 10, is a refractory-lined, sealed, stainless steel vessel of 6 feet internal diameter and approximately 7 feet internal height. The 1.5 -inch thick vessel shell made of SA $240-304 \mathrm{~L}$ steel with an OD of 8'-4.5" and an ID of 8'-1.5". It contains no remotable parts; all shell components have at least a two-year design life. Nominal melter vessel construction consists of a steel outer vessel with an inner refractory liner for primary glass containment. The outer shell is water-cooled to maintain the outer vessel at or below $50^{\circ} \mathrm{C}$. Primary glass containment is achieved by use of 12 -inch thick Monofrax K-3 fused cast refractory brick (product of Carborundum Co.).

During operation, the glass is maintained in a molten condition by passing a current from the electrodes through the resistive glass pool. Electrical energy is converted to heat inside the molten glass by Joule's Law:

$$
P=I^{2} R
$$

where $P$ is the heat produced in the glass

$I$ is the electrode current, and

$R$ is the resistivity of the glass

As a current is introduced into the glass, the high resistance of the glass converts the electrical energy into heat. The glass is maintained between $1050-1170^{\circ} \mathrm{C}$.

The DWPF melter electrodes are four uncooled plates fabricated from Inconel 690 of sufficient thickness to last greater than two years. The corrosion rate of the Inconel 690 in the glass pool is expected to be less than $1.8 \mathrm{mils} /$ day. The electrode stems are water cooled.

The DWPF melter vessel shell is penetrated in the vapor space by four pairs of horizontal resistance-type Inconel 690 lid heaters rods. During normal operation, $220 \mathrm{~kW}$ of power is supplied to the lid heaters to heat them to $950^{\circ} \mathrm{C}$ and to maintain the melter plenum vapor space at $650-800^{\circ} \mathrm{C}$. This temperature is necessary to maintain the gas above the auto 
ignition temperature of organic compounds. Temperature control assures adequate combustion of the organics in the vapors and minimizes chemical attack on the lid heaters.

The DWPF riser heater consists of an Inconel 690 serpentine heater which surrounds the four-inch inside diameter Inconel 690 riser channel. The pour spout heater also consists of an Inconel 690 serpentine heater that surrounds the two-inch diameter of the pour spout channel. Current passing through these strip heaters produces the power to keep the glass flowing through the riser and pour spout channels at a temperature between $1050-1100^{\circ} \mathrm{C}$.

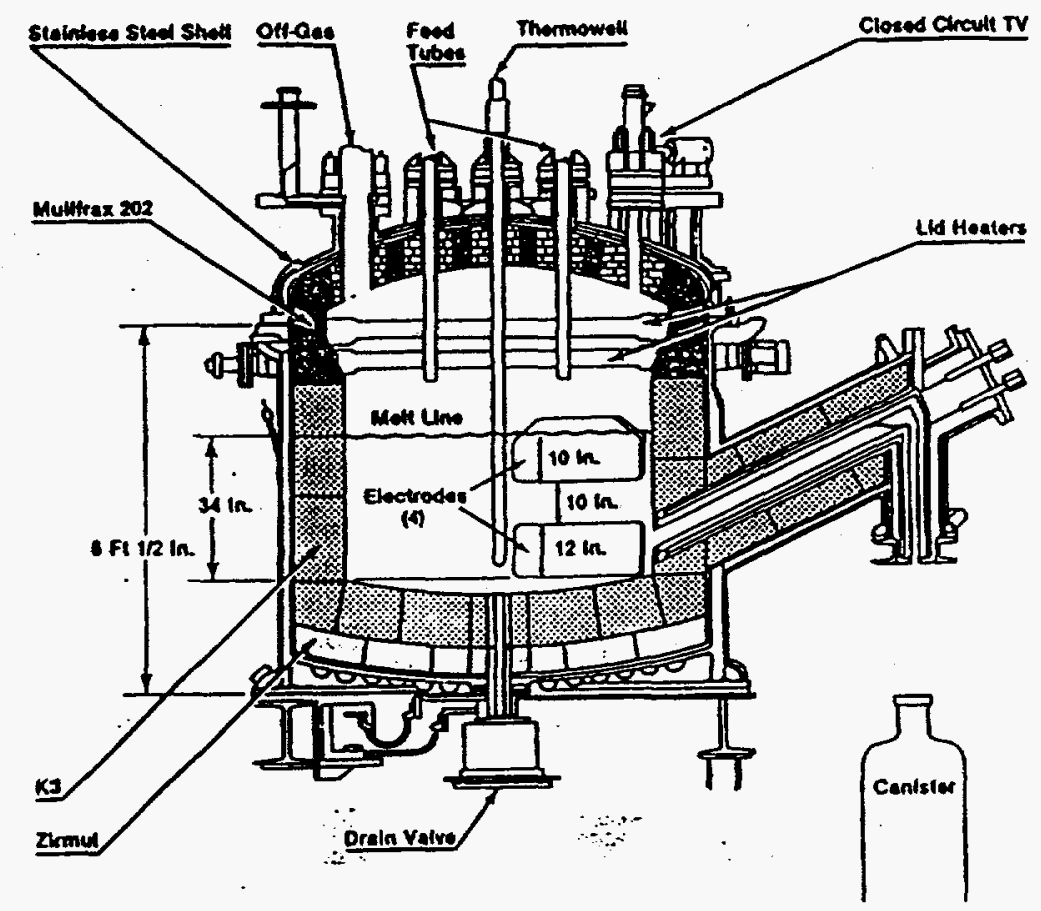

Figure 10. DWPF Melter

The IDMS Melter shell design is basically the same as that of the DWPF Scale Glass Melter (SGM). An additional 12 inches of Monofrax K-3 was added to the lower interior walls of the melt tank to reduce its diameter from 48 inches to 24 inches. This gives a melt pool surface area which is approximately $1 / 9^{\text {th }}$ that of the DWPF Melter. Melt rate is directly proportional to the surface area. Therefore, the IDMS Melter can be slurry-fed to produce glass at $25 \mathrm{lb} / \mathrm{hr}$, as compared to $228 \mathrm{lb} / \mathrm{hr}$ for the DWPF Melter. Table 4 gives a comparison of the two melters. Figure 11 shows a cross-sectional view of the IDMS melter. 
Table 4. IDMS/DWPF Melter Comparison

Parameter
Melt surface area
Melt volume
Centerline depth
Glass content (max)
Production rate
Melt rate
Residence time

IDMS Melter
$3 \mathrm{ft}^{2}\left(0.29 \mathrm{~m}^{2}\right)$
$18 \mathrm{ft}^{3}\left(0.20 \mathrm{~m}^{3}\right)$
$27 \mathrm{in}(69 \mathrm{~cm})$
$1063 \mathrm{lbs}(482 \mathrm{~kg})$
$24 \mathrm{lb} / \mathrm{hr}(11 \mathrm{~kg} / \mathrm{hr})$
$8 \mathrm{lb} / \mathrm{hr} / \mathrm{ft}^{2}$
$44 \mathrm{hrs}$

DWPF Melter
$28 \mathrm{ft}^{2}\left(2.61 \mathrm{~m}^{2}\right)$
$87.6 \mathrm{ft}^{3}\left(2.48 \mathrm{~m}^{3}\right)$
$37 \mathrm{in}(95 \mathrm{~cm})$
$13,136 \mathrm{lbs}(5956 \mathrm{~kg})$
$228 \mathrm{lb} / \mathrm{hr}(103 \mathrm{~kg} / \mathrm{hr})$
$8 \mathrm{lb} / \mathrm{hr} / \mathrm{ft}^{2}$
$58 \mathrm{hrs}$

The melter vessel is lined with $\mathrm{K}-3$ refractory to provide containment of the molten glass. The entire shell is water-cooled to freeze any glass that may penetrate between the refractory blocks before it reaches the shell. Two pairs of diametrically opposed Inconel ${ }^{\mathrm{TM}} 690$ electrodes provide about $35 \mathrm{~kW}$ of power to maintain the glass temperature between $1100^{\circ} \mathrm{C}$ and $1150^{\circ} \mathrm{C}$. The $\mathrm{A}$ and $\mathrm{C}$ electrode stems are water-cooled, and the $\mathrm{B}$ and $\mathrm{D}$ stems are aircooled to freeze any glass that could potentially leak out where the stems penetrate the refractory. Air (instead of water) is used on the B and D electrode stems to reduce heat loss in the unheated riser throat region. Each electrode pair (A-B and C-D) is controlled separately to permit diversion of power to the lower or upper melt pool. Table 5 gives characteristics of the IDMS and DWPF full scale electrodes.

Power supplies for the electrodes can provide up to $300 \mathrm{~V}$ single phase, but under normal conditions only $53 \mathrm{~V}$ single phase will be required. Power to the electrodes is controlled by silicon controlled rectifiers (SCR's) on the primary side of the power supply transformers. Due to the high current (approximately $400 \mathrm{amps}$ ), water-cooled cables deliver the power to the electrodes from the secondary side of the transformer.

Two horizontally-entering Inconel' 690 lid heaters, each made of two elements, provide an additional $60 \mathrm{~kW}$ of heat to vaporize water from the slurry feed, melt and the glass, and combust any organics in the feed. These heaters are also the primary source of heat during melter startup. The lid heaters are maintained at $950^{\circ} \mathrm{C}$ by passing current through the tubes. The surface temperature of the heaters is limited to $950^{\circ} \mathrm{C}$ because of thermal creep considerations (this is also the case for the DWPF melter lid heaters).

As in the DWPF glass flows from the melter up through a heated riser channel and then down a heated pour spout channel into a canister which holds up to $200 \mathrm{lbs}$ of glass. The riser is a 2 -inch diameter Inconel ${ }^{\mathrm{TM}} 690$ pipe surrounded by a serpentine Inconel $690^{\mathrm{TM}}$ heater. The heater is isolated from the Inconel ${ }^{\mathrm{TM}}$ pipe and housing with ceramics. The heater is used to maintain the glass in the channel at $1100^{\circ} \mathrm{C}$. 
The pour spout heater is constructed similarly to the riser heater. It is used to keep the glass above $1050^{\circ} \mathrm{C}$ to keep it free flowing. Power to the riser and pour spout heaters is controlled by SCR's on the primary side of the power supply transformers.

Pouring is initiated by creating a vacuum at the canister relative to the melter vapor space. A flexible set of stainless steel bellows provides a vacuum seal between the melter and the canister during pouring. These canisters are 31 inches tall and 10 inches in diameter. Although the slurry is fed continuously to the melter, glass is poured in batches. This is due to the fact that the minimum acceptable pour rate to prevent wavering of the pour stream (about $60 \mathrm{lb} / \mathrm{hr}$ ) is higher than the melt rate of $25 \mathrm{lb} / \mathrm{hr}$ for the IDMS. Melter.

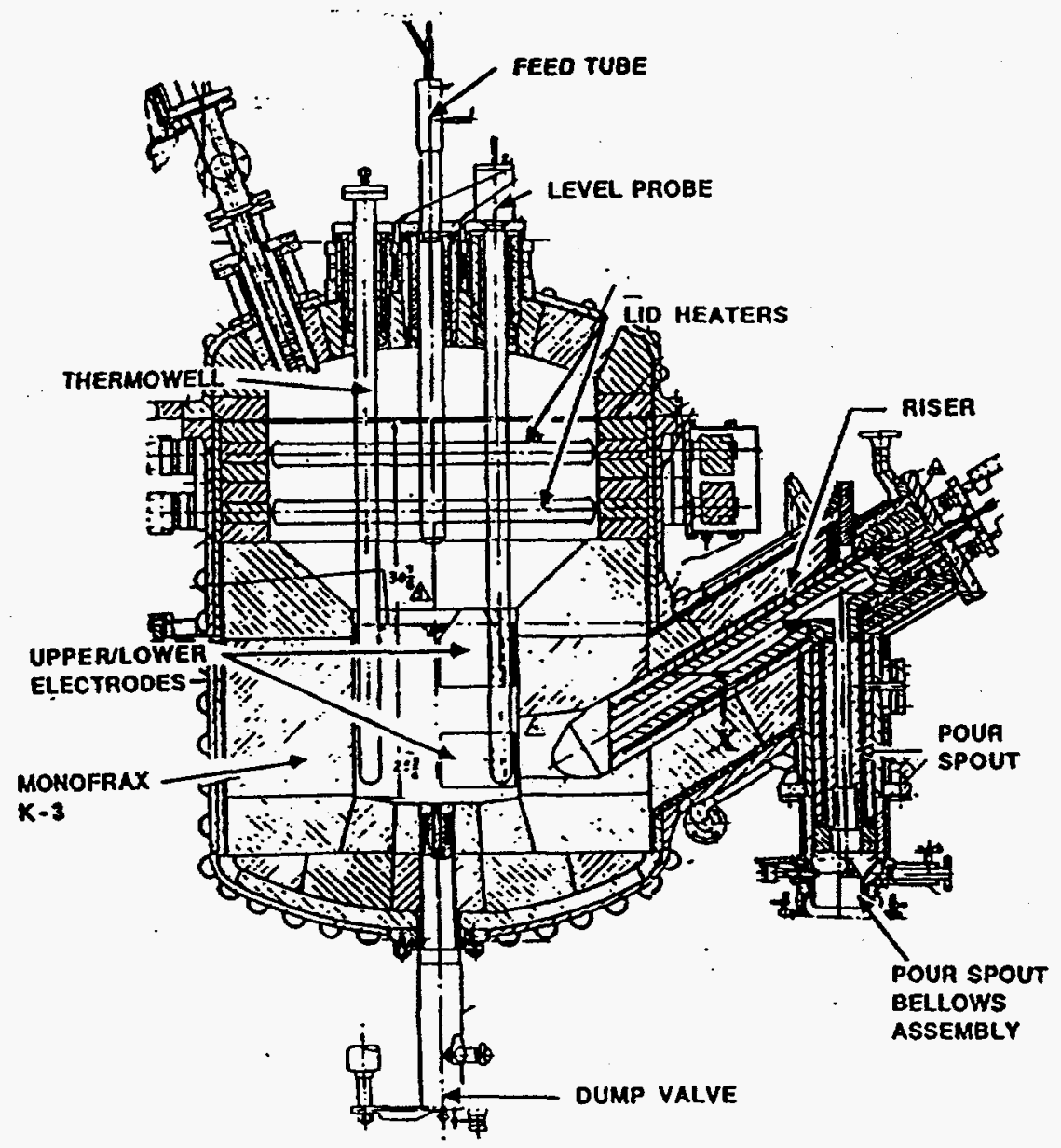

Figure 11. Cross-Sectional View of the IDMS Melter 
Table 5. Characteristics of Melter Electrodes

Characteristic

Upper pair surface area $\left(\mathrm{ft}^{2}\right)$

Lower pair surface area $\left(\mathrm{ft}^{2}\right)$

Electrode power $(\mathrm{kW})$ *

Design current density (amps/in ${ }^{2}$ )

Distance between electrodes:

- across melter (in)

- top and bottom (in)**

- and the floor (in) $\dagger$
IDMS Melter

1.00

0.74

20.0

5.0

41.2

6.75

2.5
DWPF Melter

9.49

11.00

80.0

5.0

56.0

10.0

$-$

* per pair under normal operation

** distance between bottom of top set of electrodes and the top of the bottom set of electrodes

$\dagger$ distance between the bottom of the bottom electrode and the melter floor immediately below

\subsection{Melter Offgas System}

The IDMS Melter Offgas System is a scaled simulation of the DWPF system. It was designed for an off-gas flow rate of $350 \mathrm{lb} / \mathrm{hr}$ entering the SAS's, compared with $1900 \mathrm{lb} / \mathrm{hr}$ for the DWPF. The off-gas consists of steam, non-condensable gases from sludge decomposition and volatilization, air from in leakage and purges, mercury vapor, and particulate matter from entrainment. The purposes of the off-gas system are to maintain a negative pressure in the melter plenum, to provide adequate combustion in the melter vapor space, ensure ventilation and treatment of the reaction gases and steam released from the melter, and provide melter pour spout vacuum to initiate and control glass pouring. Since there are no radionuclides present in the IDMS, the demand on the IDMS off-gas system is less than for the DWPF off-gas system. However, to enable adequate evaluation of the processing efficiency, mechanical reliability, corrosion, and fouling of filters, demister pads, and heat exchange surfaces, all of the DWPF processing steps are incorporated into the IDMS. Unlike the DWPF, the IDMS does not have a redundant backup system. Instead, it has a bypass system which can be used if the primary system is not operative. 


\subsection{Summary of IDMS Noble Metals Runs}

The IDMS has conducted a total of 16 noble metal (or noble metal related) runs to date. They have been conducted with four types of simulated waste sludges (Blend, HM, PUREX, and NCAW) and have contained varied amounts of noble metals. Some of the sludge compositions were modified in order to judge the effects of components such as mercury and nitrite. Specific compositions of each of the sludges can be found in Campaign Summary Reports. $[17,18,19,20,21,22]$

In each run (where noble metals and mercury were added) they were added in the form as shown in Table 6.

Table 6. Additive Form of Noble Metals, etc.

\begin{tabular}{c} 
Element \\
\hline $\mathrm{Ru}$ \\
$\mathrm{Rh}$ \\
$\mathrm{Pd}$ \\
$\mathrm{Ag}$ \\
$\mathrm{Hg}$ \\
$\mathrm{Se}$ \\
$\mathrm{Te}$
\end{tabular}

Additive Form
Nitrosylruthenium Hydroxide
Rhodium Nitrate
Palladium Nitrate
Silver Nitrate
Mercuric Nitrate
Selenium Oxide
Tellurium Oxide

$\frac{\text { Additive Formula }}{\mathrm{RuNO}(\mathrm{OH})_{3}}$
$\mathrm{Rh}\left(\mathrm{NO}_{3}\right)_{3} \times \mathrm{H}_{2} \mathrm{O}$
$\mathrm{Pd}\left(\mathrm{NO}_{3}\right)_{2} \times \mathrm{H}_{2} \mathrm{O}$
$\mathrm{AgNO}$
$\mathrm{Hg}\left(\mathrm{NO}_{3}\right)_{2}$
$\mathrm{SeO}_{2}$
$\mathrm{TeO}_{2}$

Note: $\mathrm{Ru}$ added as $\mathrm{RuCl}_{3}$ in $\mathrm{PX} 6$.

A brief summary of each of the runs is given below. The amounts, types, and concentrations of the waste simulants, etc. for each run are given in Table 7 .

\subsection{Blend with Noble Metals (BL1, BL2)}

The first two IDMS runs containing noble metals were made using a Blend-type sludge simulant and are referred to as BL1 (or "Blend-1") and BL2 (or "Blend-2"). In each of the runs "Blend levels" of the noble metals, mercury, $\mathrm{TeO}_{2}$, and $\mathrm{SeO}_{2}$ were added to the sludge simulant. During these runs, hydrogen was measured as an offgas product during the feed preparation process. This hydrogen was due to the noble metal catalyzed decomposition of formic acid. Because of the safety implications of this occurrence, the IDMS facility was put into an extended idling mode while safety upgrades of the facility were completed. Also, because of this, a greater emphasis was placed on research activities involving the feed preparation portion of the operation. [19,23] 


\subsection{DWPF Cold Runs Demonstrations (BL3, HM1)}

After the extended idling period, the operation in the IDMS facility resumed. The next series of runs were conducted to simulate the DWPF cold runs. The purpose was to measure the amount, if any, of hydrogen that could be expected in the DWPF Cold Chemical Runs (in the absence of the noble metals). Thus, these runs did not contain noble metals, mercury, $\mathrm{TeO}_{2}$, or $\mathrm{SeO}_{2}$. The two runs are referred to as BL3 and HM1 (or "HM-1"). [20]

\subsection{DWPF RadOp Design Basis Runs (HM2, HM3, PX1, PX2)}

The next set of runs were conducted to provided the DWPF with design information for modifications for radioactive operations (for hydrogen evolution). This set of operations consisted of 2 runs using HM-type sludge and 2 runs using PUREX-type sludge. The runs are referred to as HM2, HM3, PX1 (or "PUREX-1"), and PX2. In each of the runs "HM levels" of the noble metals, $\mathrm{TeO}_{2}$, and $\mathrm{SeO}_{2}$ were added to the sludge simulant. Mercury was not included in any of the runs. The noble metals were added at "HM-levels" in all of the runs because this was the highest concentration and would most likely give the maximum hydrogen evolution.

\subsection{Hanford Waste Vitrification Plant Demonstrations (HWVP1, HWVP2)}

Following the RadOp Design Basis Runs, two runs were conducted in support of the design and operation of the Hanford Waste Vitrification Plant (HWVP). These runs were conducted with a NCAW waste simulant containing nominal levels of noble metals and are referred to as HWVP1 and HWVP2.[22]

\subsection{Nitric Acid Flowsheet - HAN PHA (HM4, PX3)}

The next set of IDMS operations were conducted in order to test the "Nitric Acid Flowsheet". This flowsheet was developed as a way to reduce the amount of hydrogen and ammonia which will be evolved during the feed preparation process. The runs used HM and PUREX type sludges with HM levels of noble metals and mercury. In each case, HAN-type PHA was added in the feed preparation process.

\subsection{Nitric Acid Flowsheet - Late Wash PHA (PX4, PX5, PX6)}

The last IDMS runs demonstrated the use of the "Nitric Acid Flowsheet" with "Late Wash PHA". This operation is currently the reference flowsheet combination employed by the DWPF. Both of these runs used PUREX sludge with HM levels of noble metals and mercury. 
Table 7. IDMS Run Summary

\begin{tabular}{|c|c|c|c|c|c|c|c|c|c|}
\hline Run & ID & $\begin{array}{c}\text { Sludge } \\
\text { Type }\end{array}$ & PHA Type & $\begin{array}{l}\text { Frit } \\
\text { Type }\end{array}$ & $\begin{array}{l}\text { Acid } \\
\text { Type }\end{array}$ & $\begin{array}{l}\text { Mercury } \\
\text { Amounts }\end{array}$ & $\begin{array}{c}\text { NM } \\
\text { Amounts }\end{array}$ & $\begin{array}{c}\text { Te, Se } \\
\text { Amounts }\end{array}$ & $\begin{array}{c}\text { Glass Prod } \\
\text { (Ibs) }\end{array}$ \\
\hline end1 & BL1 & Blend & HAN & FRIT-202 & $\begin{array}{l}90 \% \\
\text { Formic }\end{array}$ & Blend & Blend & Blend & 2970 \\
\hline end2 & BL2 & Blend & HAN & FRIT-202 & $\begin{array}{l}90 \% \\
\text { Formic }\end{array}$ & Blend & Blend & Blend & 5376 \\
\hline end3 & BL3 & Blend & HAN & FRIT-202 & $\begin{array}{l}90 \% \\
\text { Formic }\end{array}$ & None & None & None & 1595 \\
\hline M! & HM1 & HM & HAN & FRIT-202 & $\begin{array}{l}90 \% \\
\text { Formic }\end{array}$ & None & None & None & 3156 \\
\hline M2 & HM2 & HM & HAN & FRIT-202 & $\begin{array}{l}90 \% \\
\text { Formic }\end{array}$ & None & HM & HM & 2949 \\
\hline M3 & HM3 & HM & HAN & FRIT-202 & $\begin{array}{c}90 \% \\
\text { Formic }\end{array}$ & None & HM & HM & 3635 \\
\hline UREXI & PXI & PUREX & HAN & FRIT-202 & $\begin{array}{l}90 \% \\
\text { Formic }\end{array}$ & None & $H M$ & HM & 3344 \\
\hline UREX 2 & PX2 & PUREX & HAN & FRIT-202 & $\begin{array}{c}90 \% \\
\text { Formic }\end{array}$ & None & HM & HM & 4232 \\
\hline HWVPI & HVI & NCAW & NA (RWS) & $\begin{array}{l}\text { PNNL } \\
\text { FY'92 }\end{array}$ & $\begin{array}{l}90 \% \\
\text { Formic }\end{array}$ & NCAW (none) & NCAW & NCAW & 3390 \\
\hline HWVP2 & HV2 & NCAW & NA (RWS) & $\begin{array}{l}\text { PNNL } \\
\text { FY'92 }\end{array}$ & $\begin{array}{c}90 \% \\
\text { Formic }\end{array}$ & NCAW (none) & NCAW & NCAW & 4561 \\
\hline HM4 & HM4 & HM & HAN & FRIT-202 & 8 M Nitric & HM & HM & HM & 3226 \\
\hline UREX3 & PX3 & PUREX & HAN. & FRIT-202 & 8 M Nitric & HM & HM & HM & 5108 \\
\hline PUREX4 & PX4 & PUREX & Late Wash & FRIT-202 & 8 M Nitric & HM & $H M$ & HM & 4850 \\
\hline DUREXS & PX5 & PUREX & Late Wash & FRIT-202 & $8 \mathrm{M}$ Nitric & HM & HM & HM & 4075 \\
\hline UREX6 & PX6 & PUREX & Late Wash & FRIT-202 & 11 M Nitric & $\mathrm{HM}$ & HM & HM & $* 1693$ \\
\hline
\end{tabular}

Sludge Noble Metal, etc. Concentrations

\begin{tabular}{|cccccc} 
Element & $\begin{array}{c}\text { Blend } \\
\text { wt\% }\end{array}$ & $\begin{array}{c}\text { HM } \\
\text { wt\% }\end{array}$ & $\begin{array}{c}\text { PUREX } \\
\text { wt\% }\end{array}$ & $\begin{array}{c}\text { TANK 51 } \\
\text { wt\% }\end{array}$ & $\begin{array}{c}\text { NCAW } \\
\text { wt\% }\end{array}$ \\
\hline Ru & 0.100 & 0.217 & 0.028 & 0.007 & 0.231 \\
Rh & 0.018 & 0.038 & 0.008 & 0.001 & 0.064 \\
Pd & 0.045 & 0.079 & 0.026 & 0.006 & 0.080 \\
Ag & 0.014 & 0.014 & 0.014 & 0.014 & 0.084 \\
& & & & & \\
Hg & 1.588 & 3.263 & 0.102 & 0.192 & 0.000 \\
& & & & & \\
Te & 0.022 & 0.048 & 0.006 & 0.00009 & 0.060 \\
Se & 0.002 & 0.004 & 0.001 & 0.0007 & 0.009 \\
\end{tabular}

* Only a portion of PX6 was fed to the IDMS melter. 


\subsection{IDMS Melter Shutdown/Inspection}

The IDMS melter was shutdown on June 30, 1995 after operating continuously since October 1988. An inspection of the melter refractory, melter component, and off-gas piping, as well as sampling of the material at the bottom of the melter was done. Aggressive attack of the K-3 refractory occurred at the bottom of the melter drain. The Inconel $690 @$ drain valve and pipe had extensive corrosion. The Inconel $690 @$ upper electrode was in excellent condition above the normal glass level while the bottom of the electrode exhibited some wear. The Inconel $690 \otimes$ lower electrode, continuously in contact with the melt, had lost about $12 \%$ of the material from the face of the electrode. 


\subsection{Behavior of the Noble Metals}

\subsection{Size, Distribution and Chemical Form}

The rate of accumulation of the noble metals in the melter is a function of the size, distribution, and chemical forms of the noble metals and/or the noble metal compounds in the glass. Samples were taken from various points in the melter system in order to understand how the different processing steps affect these parameters. Each of these samples were examined by a variety of analytical methods and are described below.

\subsubsection{In the Melter Feed Slurry}

In each of the runs, the noble metal compounds were added to the alkaline waste sludge simulant in the SRAT/SME vessel. The palladium, rhodium, and silver were added as nitrate solutions. The ruthenium was purchased as $\mathrm{RuCl}_{3}$ and was subsequently converted (except for PX6 when it was added as $\mathrm{RuCl}_{3}$ ) to a nitrosylruthenium hydroxide (RuNO(OH)3) slurry (the anticipated form of the ruthenium in the SRS waste). The procedure for this conversion was developed by R. M. Wallace and D. T. Hobbs of the Savannah River Technology Center. While the procedure may not produce a purely nitrosylruthenium solution, it does result in a product which has undergone similar treatment as the actual SRS waste. Selenium and Tellurium were added as dioxides. The resultant waste sludge simulant was acidified with either formic or nitric acid and blended with other simulated wastes (PHA or RWS) and a glass forming frit with the final mixture being the slurry which was fed to the melter.

The size, distribution, and chemical forms of the noble metals in the melter feed slurry are expected to greatly influence the size, distribution, and chemical form in the melter and glass product. The size, distribution, and chemical form of the noble metals in the melter feed are most affected by a combination of the upstream processing steps (especially by the addition of a reductant, formic acid), and the physical treatment of the material in the SRAT, SME, and MFT. The size and distribution of the noble metals are affected by the shearing actions of the vessel agitators and the melter feed pump. Further, the presence of mercury also affects the distribution of some of the noble metals.

Feed slurry samples were taken during periods of continuous melter feeding. These samples were then dried, washed with distilled water, and centrifuged. The resulting insoluble solids were examined by Scanning Electron Microscopy/Energy Dispersive X-Ray (SEM/EDX). These analyses revealed scattered palladium "nuggets" of about $1 \mu \mathrm{m}$ and, in melter feeds containing mercury, amalgams of $\mathrm{Hg} / \mathrm{Ag}$ and $\mathrm{Hg} / \mathrm{Ag} / \mathrm{Pd}$. Although one very small aggregate of $\mathrm{Ru} / \mathrm{Pd} / \mathrm{Ag}$ was seen in the second Hanford NCAW run (HWVP2), no individual or amalgamated $\mathrm{Ru}$ or $\mathrm{Rh}$ particles were been observed in any of the melter feed slurry insoluble solids. It is suspected that these species, if reduced to the elemental state, form 
very small sub-micron particles which cannot easily be found by standard optical microscopy. In general, in the melter feed slurry, the noble metals are present as either very small, finely dispersed particles or as soluble salts. $[24,25]$

\subsubsection{In the Melter Cold Cap}

During continuous feeding of the simulant slurry, a "cold cap" region forms on the surface of the molten glass. It is in this area that almost all reduction/oxidation reactions occur and gaseous vitrification products are evolved. After material has been feed to the melter to form a cold cap which sufficiently covers the molten glass, a dip sample of the cold cap region can be obtained. Analysis of these partially vitrified samples have revealed $\mathrm{RuO}_{2}$ needles of up to $20 \mu \mathrm{m}$ long present in 20 to $50 \mu \mathrm{m}$ clusters. The samples have also contained scattered 1 $\mu \mathrm{m}$ AgI salts, RuS2, Pd tellurides and selenides, and complex mixtures of $\mathrm{Pd} / \mathrm{Ag} / \mathrm{Te} / \mathrm{I} / \mathrm{S} / \mathrm{Cu}$. These cold cap samples also provided some evidence as to how this area physically and chemically influences the agglomeration of these species. The SEM micrographs indicated the noble metal compounds (especially the Pd) were preferentially located on the surface of vitrified "gas bubbles". This suggests that the frothing which takes place as a result of vitrification offgases may promote the growth of platinum metal nodules.[24] It has also been suggested that palladium oxides may decompose to metallic Pd and oxygen, with the Pd transported to the melt surface within the oxygen bubble.[26] Once at the melt surface the Pd particles may combine with other free particles to form nodules which will then settle to the melter floor.

Figure 12 shows a SEM micrograph of a melter cold cap sample (H-COLD-0238) showing the partially vitrified sample and the vitrification offgas "bubbles". Figure 13 shows a more detailed micrograph of melter cold cap sample 1-COLD-3690 showing small noble metal particles and salts $\left(\mathrm{RuO}_{2}, \mathrm{RuS}_{2}, \mathrm{AgI}, \mathrm{AgCl}\right.$, and other complex mixtures containing $\mathrm{Te}, \mathrm{Se}$, $\mathrm{I}$, and $\mathrm{Cu}$ ). 


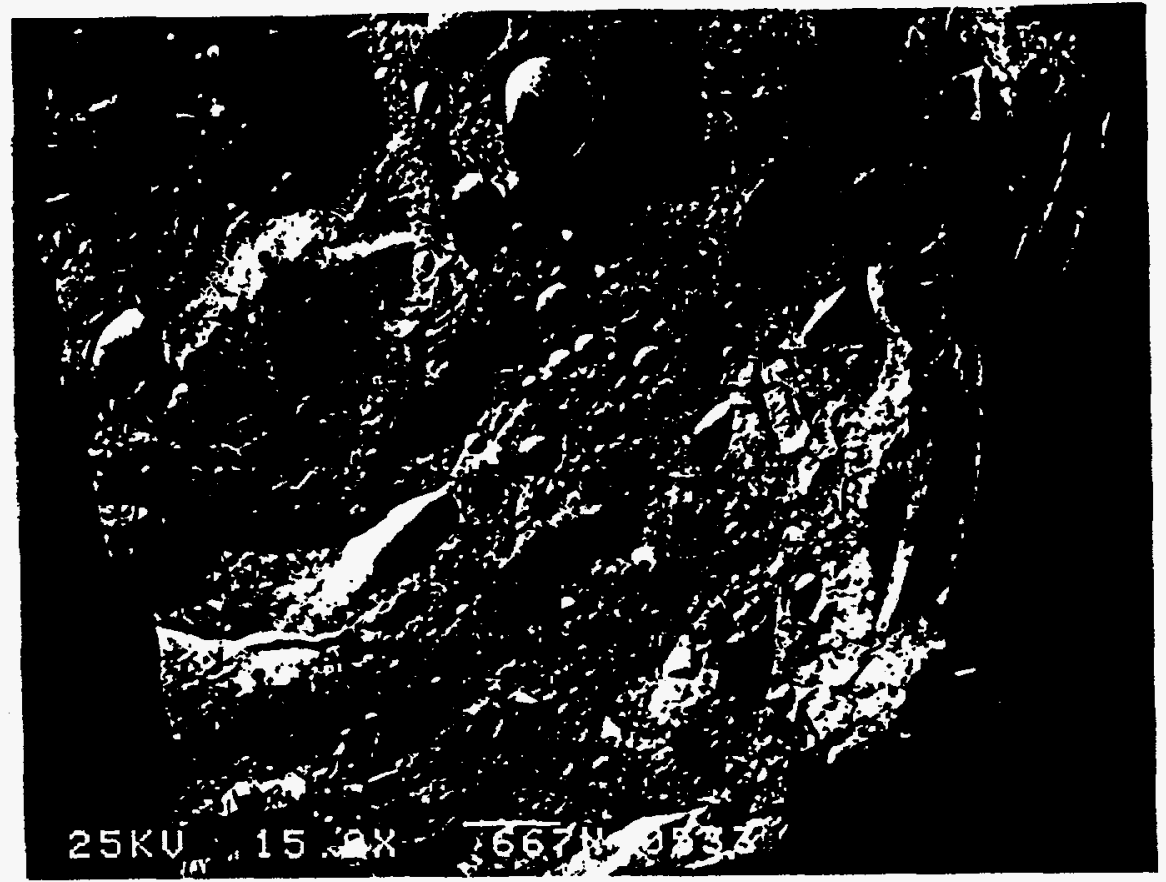

Figure 12. SEM Micrograph of IDMS Melter Cold Cap Sample (H-COLD-0238)

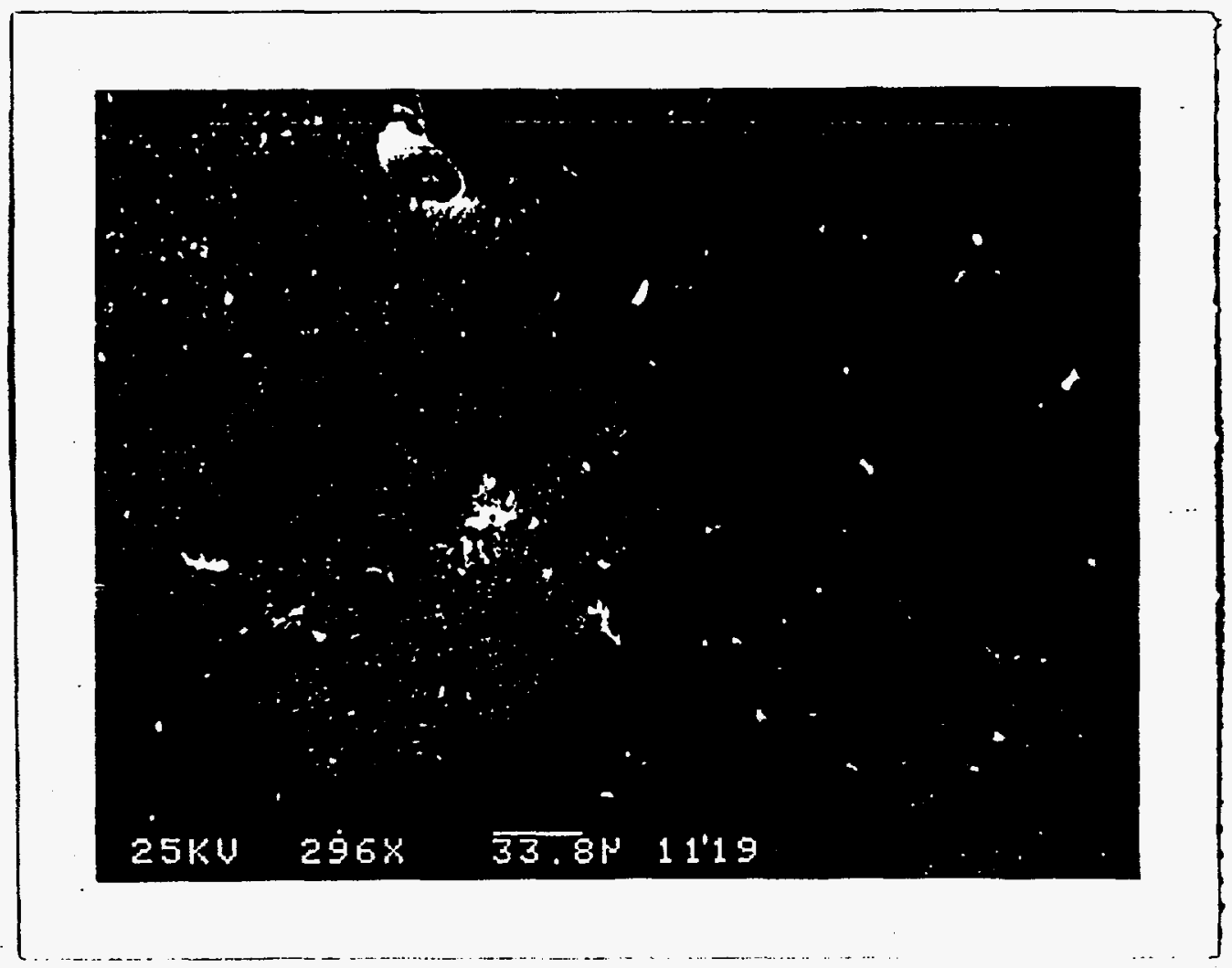

Figure 13. SEM Micrograph of IDMS Melter Cold Cap Sample (I-COLD-3690) 


\subsubsection{In the Melter Offgas Deposits / Offgas Condensate}

The formation of deposits in the melter offgas line has been a problem common to all slurryfed melters. These deposits have normally been composed of alkali-rich chlorides, sulfates, borates, and fluorides with entrained $\mathrm{Fe}_{2} \mathrm{O}_{3}$, spinels, and frit particles. The melter offgas deposit samples obtained from the IDMS melter were composed of these same components and have also contained trace quantities of $\mathrm{RuO}_{2},(\mathrm{Ru}, \mathrm{Rh}) \mathrm{O}_{2}$, and $\mathrm{Ru} / \mathrm{Rh} / \mathrm{Te}$ mixtures (and some entrained Cd compounds during the NCAW processing).[22,24] While the formation of $\mathrm{RuO}_{4}$; a toxic gas, is possible in very oxidizing conditions, most of the $\mathrm{Ru}$ exiting the melter was the result of entrainment rather than volatility as the $\mathrm{RuO}_{2}$ in the melter offgas deposits were most often associated with entrained spinel crystals.

Analysis of the soluble fraction of the melter offgas condensate revealed very low concentrations of the noble metals. However, analysis of the insoluble solids present in the offgas condensate showed the solids to contain $\mathrm{RuO}_{2}$ crystals, spinels, and insoluble silver halide ( $\mathrm{AgI}, \mathrm{AgCl}$ ) salts. However, the amount of the noble metals exiting the melter through the offgas line is small and should not significantly affect the overall mass balance of any of the elements.

\subsubsection{In the Canistered Glass Product}

The canistered glass products of several IDMS campaigns have been examined by SEM/EDX. Ruthenium was the most frequently observed of the platinum metals in the glass product. The ruthenium was present as both individual and clustered acicular (needlelike) $\mathrm{RuO}_{2}$ crystals (See Figure 14) which were usually $<10 \mu \mathrm{m} .[22,24,25]$

The $\mathrm{RuO}_{2}$ was also quite often associated with $(\mathrm{Ni}, \mathrm{Mn}) \mathrm{Fe}_{2} \mathrm{O}_{4}$ and $(\mathrm{Ni}, \mathrm{Mn}) \mathrm{Cr}_{2} \mathrm{O}_{4}$ spinels. It had been previously shown that $\mathrm{RuO}_{2}$ will serve as a seed for the heterogeneous nucleation of these spinels. [27] The SEM/EDX analysis of the IDMS glass also revealed spinel growth which had been nucleated by aggregates of $(\mathrm{Ru}, \mathrm{Rh}) \mathrm{O}_{2}, \mathrm{Ru} / \mathrm{Rh}, \mathrm{Ru} / \mathrm{Pd}$, and $\mathrm{Rh} / \mathrm{Pd}$. Upon further analysis via Transmission Electron Microscopy (TEM), it was found that the $\mathrm{Ru}$ and $\mathrm{Rh}$ oxides not only act as nucleating agents for the formation of the spinel structure but the $\mathrm{Ru}$ and $\mathrm{Rh}$ have also substituted with other spinel components (See Figure 15) to become part of the spinel structure itself.

Palladium, as $\mathrm{Pd}$ and $\mathrm{Pd} / \mathrm{Te}$, was also occasionally found in the canistered glass product. The silver is completely dissolved within the glass matrix. 


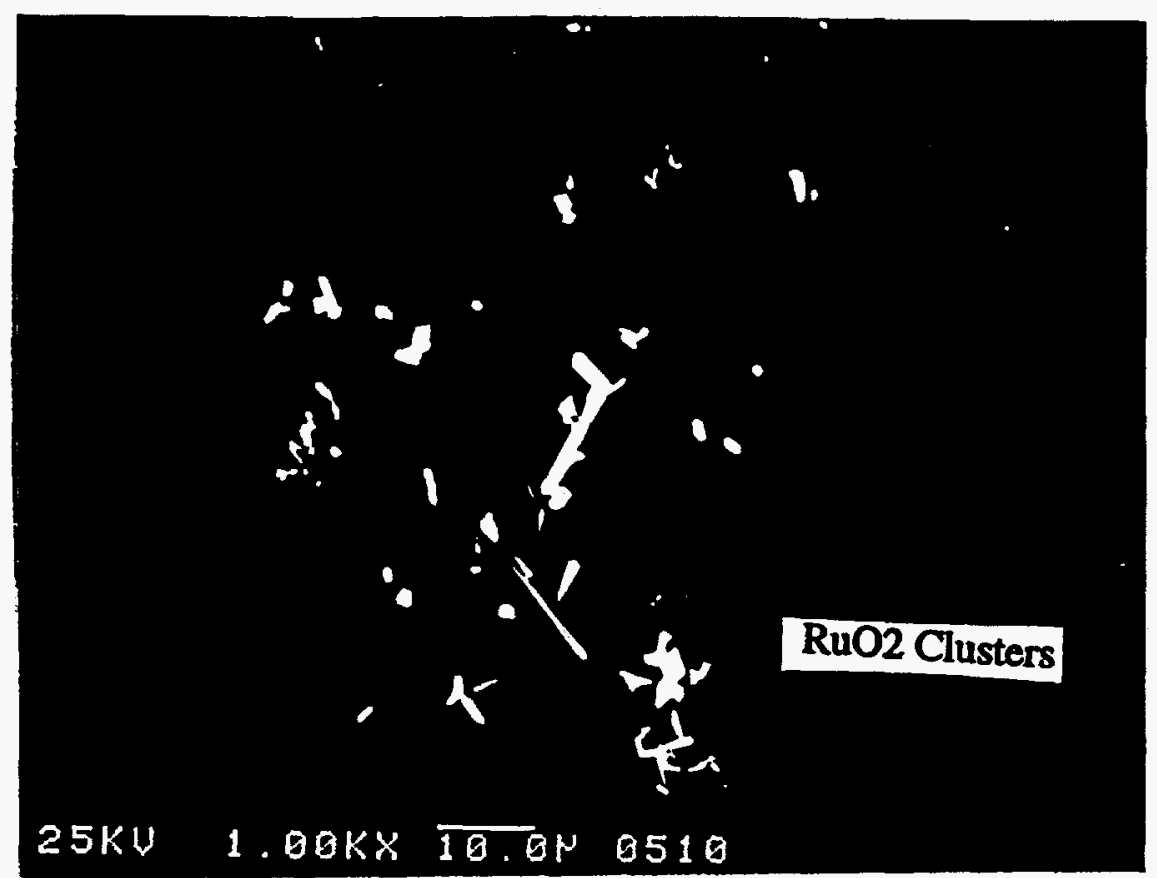

Figure 14. SEM Micrograph of IDMS Canistered Glass Product (H-GLAS-0264)

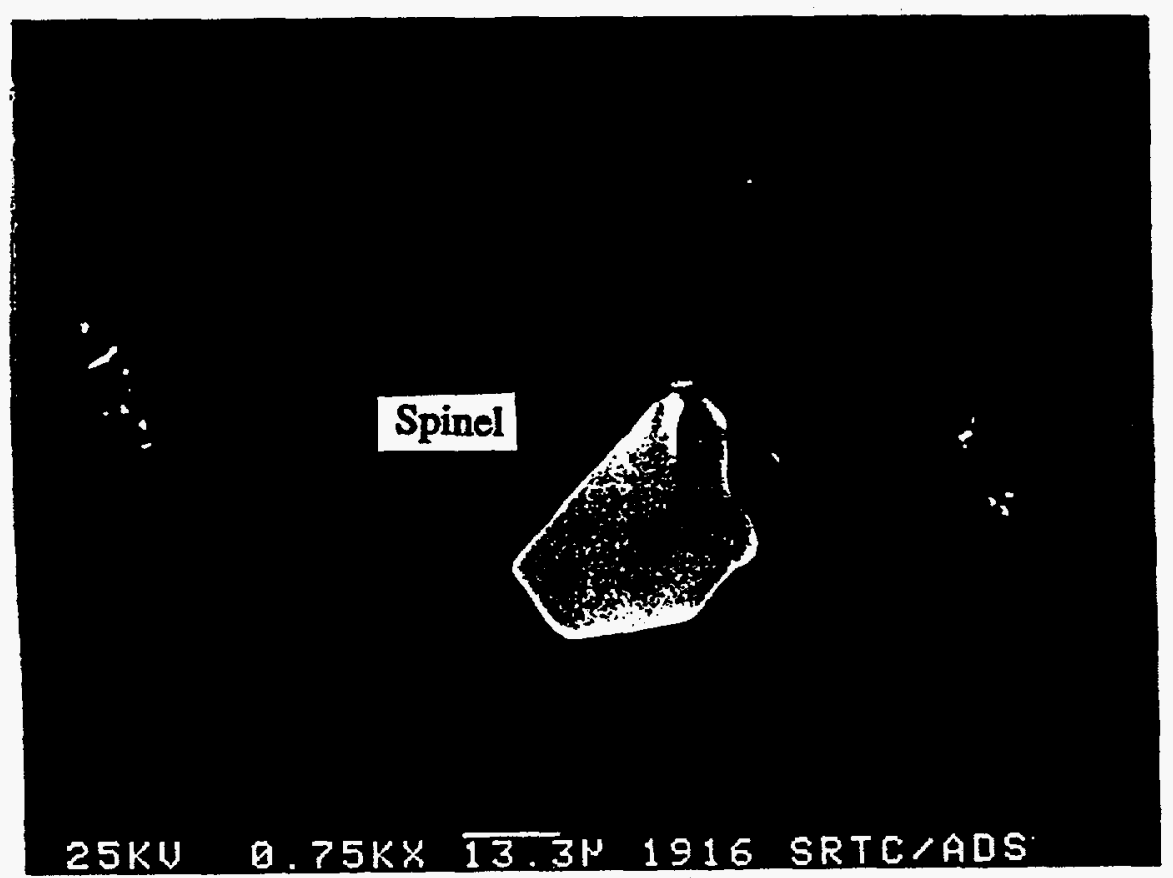

Figure 15. SEM Micrograph of IDMS Canistered Glass Product (H-GLAS-0446) 


\subsubsection{In the Melter Floor Samples}

Since the introduction of noble metals in the IDMS melter, samples of the melter floor have been taken on a regular basis. The samples are taken using a "grain thief" type sampling device. The samples are normally taken through the feed tube port but have also been taken from the borescope port (See Figure 16).

About 2 months after feeding the initial noble metal doped slurry, a sample was taken of the melter floor (actually at about 1-2 inches above the floor). The sample revealed no evidence of the presence of any noble metals or crystalline material. Another sample of the melter floor (again at about 1-2 inches) was taken approximately 5 months after the initial floor sample. This sample showed very scattered $\mathrm{RuO}_{2}$ needles approximately 5 to $15 \mu \mathrm{m}$ long. These needles were present, for the most part, in 20 to $40 \mu \mathrm{m}$ clusters. There was no evidence of any deposition of $\mathrm{Pd}, \mathrm{Rh}, \mathrm{Ag}, \mathrm{Se}, \mathrm{Te}$ or any of their compounds.

Approximately 13 months after the introduction of the noble metals, a third melter floor sample was taken. The sampler was modified so that samples could be taken to within 1/2inch of the melter floor. This sample revealed a significant increase in the amount of $\mathrm{RuO}_{2}$ from the earlier samples (Figure 17). There was also evidence of a small amount of Pd deposition. The sample was, however, relatively free of spinel accumulation.

Since there was a considerable increase in the amount of deposited $\mathrm{RuO}_{2}$, the frequency of melter floor sampling was increased and another sample was taken at 15 months into noble metal operations. This sample (I-MELT-4790) was just before the start of the feeding of the first batch of NCAW feed slurry. Micrographs of this sample revealed a dense layer of melt insolubles, mainly $\mathrm{RuO}_{2}$ and $(\mathrm{Ni}, \mathrm{Mn})(\mathrm{Fe}, \mathrm{Cr})$ spinels (Figure 18). This sample also revealed the first evidence of Rh deposition on the melter floor (Figure 19). On sampling of this material, it was noted that there was an obvious layer on the melter floor that was much more viscous than the bulk glass. This viscous layer (of approximately 1-2 inches) has been obvious in every melter floor sample taken thereafter.

Another sample was then taken at 16.5 months into processing which was during the feeding of the HWVP1 melter feed slurry. This sample (H-MELT-0330, shown in Figure 20) again revealed significant $\mathrm{RuO}_{2}$ and spinel accumulation and also individual metallic $\mathrm{Pd}$. After the completion of the feeding of the HWVP1 melter feed, a sample was again taken of the melter floor (17 months). This sample, (H-MELT-0329) as before, revealed dense $\mathrm{RuO}_{2} /$ spinel accumulation and scattered $\mathrm{Rh}$ accumulation.

A melter floor sample was taken after completion of the feeding of the HWVP2 material (19 months). This sample (I-MELT-4804) was chemically analyzed but not examined by the microscope. The chemical analysis (Table 8) revealed that the $\mathrm{Ru}, \mathrm{Rh}$, and spinel components $(\mathrm{Cr}, \mathrm{Mn}$, and $\mathrm{Fe}$ ) had all decreased. This suggested that the noble metals and 
spinels may have been "flushed" out of the melter or possibly rearranged on the melter floor. [22]

Figures 21 and 22 show plots of the concentrations of $\mathrm{Cr}$, Ni (Figure 21) and $\mathrm{Ru}$ (Figure 22) during Hanford glass production (HWVP1 and HWVP2). One can see in Figure 21 that there is an abrupt increase in $\mathrm{Ni}$ and $\mathrm{Cr}$ (spinel components) between HWVPI and HWVP2. This, along with SEM analysis and chemical analysis of melter floor (center) samples gives further support to the theory that the spinels were moved from the melter center to the outer edge and flushed out with the glass. However, although the $\mathrm{RuO}_{2}$, it seems, was also moved from the center to the outside edge, it was not flushed. The concentration of Ru in the glass product decreased with the idling time between HWVP1 and HWVP2, thereby indicating settling of $\mathrm{RuO}_{2}$ from the bulk melt and an increase in the concentration of $\mathrm{RuO}_{2}$ on the melter floor. This apparent spinel flushing is not possibly advantageous with respect to increasing the lifetime of the melter. Since the spinels are not highly conductive, compared to the noble metal compounds, they may behave as insulators and increase the overall resistivity of the deposited material.

Another sample (I-MELT-5219) was taken at 19.5 months and is shown in Figures 23 - 25. This sample was the first taken through the borescope port. The sampling point was just at the face the bottom electrode which is closest to the riser throat entrance (see Figure 16). The SEM examination revealed that, like I-MELT-4804, there was much less of an accumulation of spinels than in previous samples. Chemical analysis confirmed that the spinel components $(\mathrm{Cr}, \mathrm{Fe}$, etc.) were indeed lower than previous samples. However, the concentration of ruthenium was much higher $(9 \mathrm{wt} \%)$ than in previous samples. This further confirmed that the spinels had been "flushed" out while the $\mathrm{RuO}_{2}$ was merely swept from the center of the melter to the outside of the melter floor. Figure 23 shows the normal $\mathrm{RuO}_{2}$ clusters, $\mathrm{Rh}$-nucleated $\mathrm{Cr} / \mathrm{Ni} / \mathrm{Fe}$ spinel, and an elongated formation of ruthenium disulfide, RuS2, a compound which decomposes at temperatures $>1000^{\circ} \mathrm{C}$. Figure 24 shows a relatively large mass of metallic palladium. Figure 25 reveals the presence of rhodium in this sample. The presence of $\mathrm{RuS}_{2}$ in this sample was quite surprising. Since this compound decomposes at temperatures $>1000^{\circ} \mathrm{C}$ [4], one can assume that the temperatures at the outside portion of the melter may have been $<1000^{\circ} \mathrm{C}$ despite the fact that the bulk glass temperature was held at $1100-1150^{\circ} \mathrm{C}$.

Another floor sample (I-MELT-5242) was then taken from the center of the melter (feed tube port) at 20 months. This sample, shown in Figure 26, revealed large masses of deposited material, mainly $\mathrm{RuO}_{2}$ and spinels.

The next sample (I-MELT-5270) was taken from the borescope port of the melter at 21 months. This sample showed a dense accumulation of noble metals and spinels and again confirmed the presence of RuS2. The analysis of this sample, as shown in Table 8, 
confirmed the increase in spinel components (especially $\mathrm{Cr}$ ). Representative micrographs are shown in Figure 27.

Table 8 shows the amounts (in wt\%) of selected components in each melter floor sample (analyses by ICP-AES/Sodium Peroxide Fusion- $\mathrm{HCl}$ uptake). These results suggest a nonuniform layer of noble metals (mainly $\mathrm{RuO}_{2}$ ) and $\mathrm{Ni} / \mathrm{Fe} / \mathrm{Cr}$ spinel on the melter floor. The samples analyses which have been shaded are those which have been taken from the borescope port. Analysis of these samples have consistently revealed a higher concentration of $\mathrm{Ru}$ as compared to the samples taken from center of the melter. This suggests that the convective currents in the melter tend to "push" the $\mathrm{RuO}_{2}$, spinels and other melt insolubles from the center of the melter (where they enter) to the outside edges. Also, these convective currents may not be the same during periods of idling since an extreme temperature gradient (the cold cap) is no longer present. This may help to explain the apparent flushing of crystalline spinels from the melter.

The accumulation of $\mathrm{RuO}_{2}$ and $\mathrm{Rh} / \mathrm{Pd} / \mathrm{Te}$ is consistent with what has been demonstrated in waste vitrification simulations in Germany. [28] However, in melter floor samples taken from a research melter in Karlsruhe, Germany, the $\mathrm{RuO}_{2}$ needles were much more acicular and perfectly formed. The $\mathrm{RuO}_{2}$ crystalline growth in SRS, Hanford, and West Valley [16] glasses and cold cap samples appear to be inhibited by the glass itself. This may be explained by the fact that glass beads are used as the primary glass forming additive in German tests while tests conducted in the IDMS facility and the West Valley SFCM used a finely ground glass frit and batch chemicals. It has been suggested that $\mathrm{RuO}_{2}$ crystals are initially formed in the melter cold cap via Ostwald ripening. Ostwald ripening may occur when a large number of crystallites differing in size are present and is characterized by simultaneous growth and dissolution of crystals in order to minimize surface free energy. The "large" voids are present between the glass beads of the German slurry feed allowing unhindered growth of the $\mathrm{RuO}_{2}$ crystals in the cold cap. Alternatively, the frits used in US melters soften at lower temperatures than the German glass beads and eliminate the voids in the cold cap thus hindering the growth of the $\mathrm{RuO}_{2}$ crystals. 
IDMS 1/20 scale Glase Helter

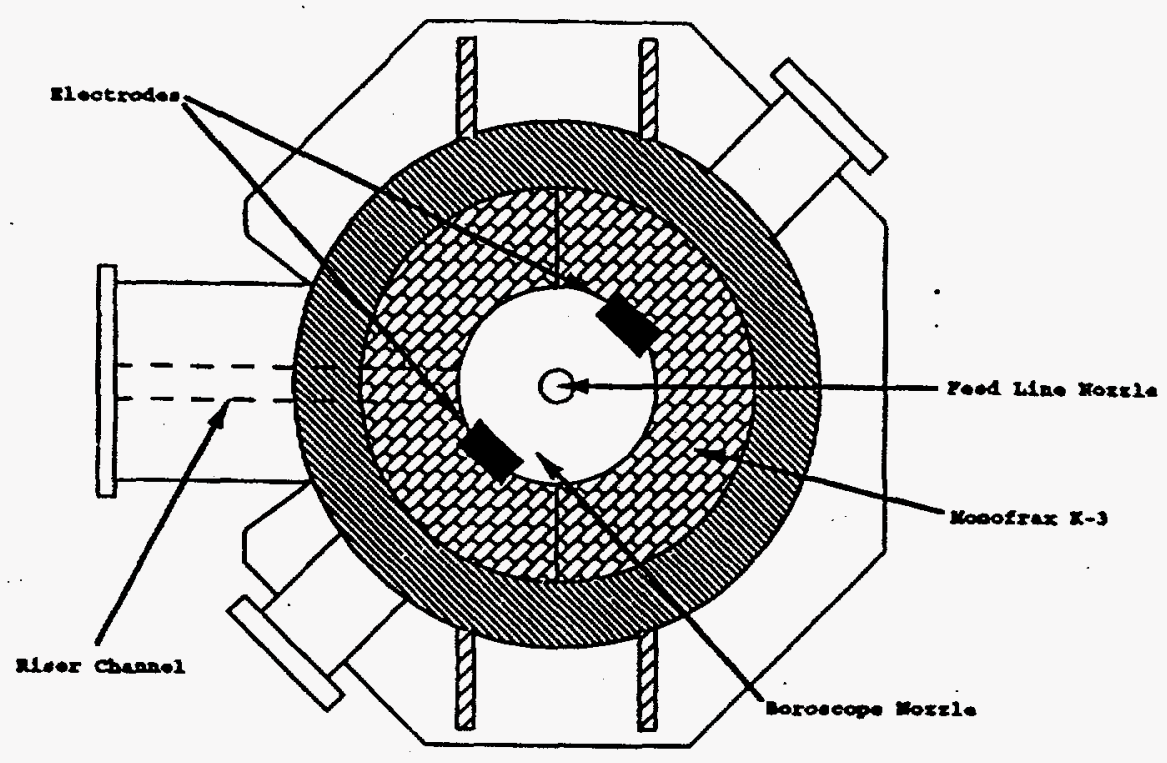

Figure 16. Top View of IDMS Melter Showing Points of Melter Floor Sampling

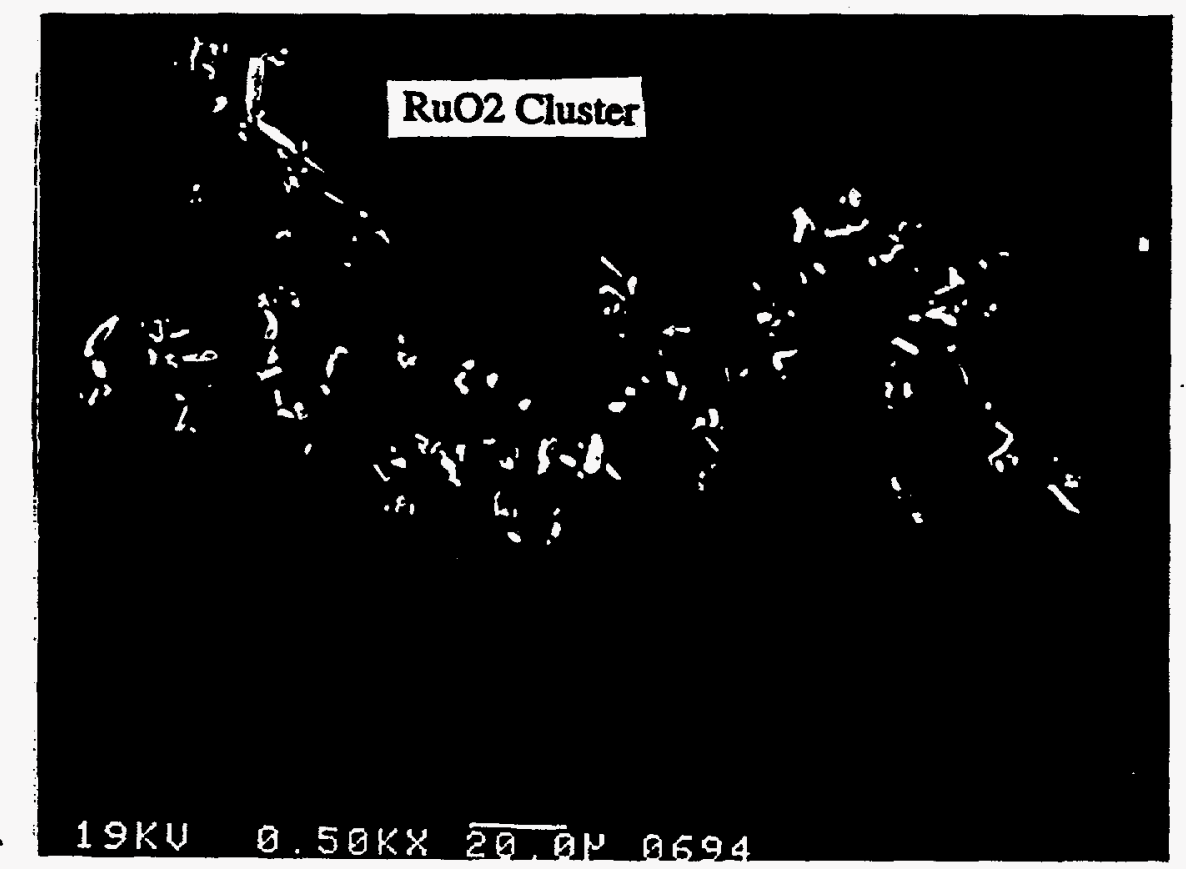

Figure 17. IDMS Melter Floor Sample (I-MELT-4312) taken 8/23/91 


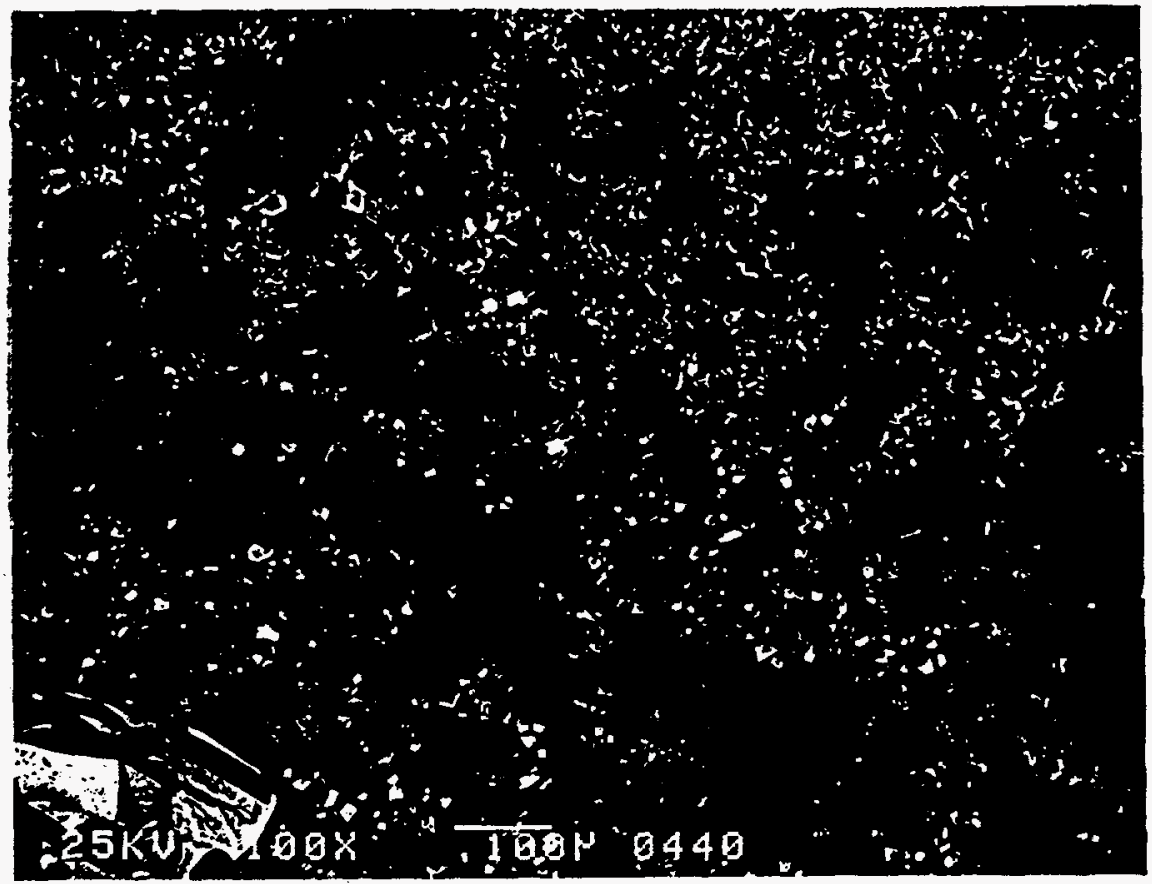

Figure 18. IDMS Melter Floor Sample (I-MELT-4790) taken 10/15/91

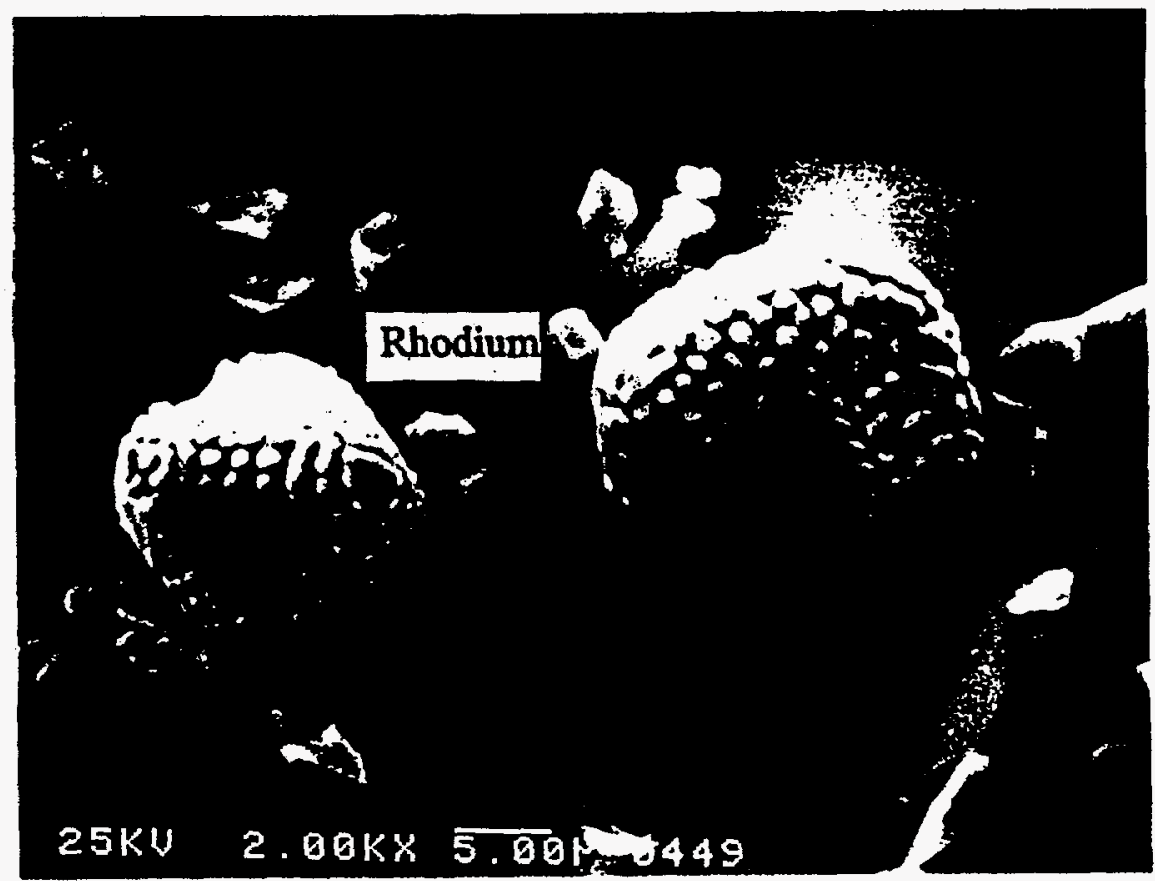

Figure 19. IDMS Melter Floor Sample (I-MELT-4790) taken 10/15/91 


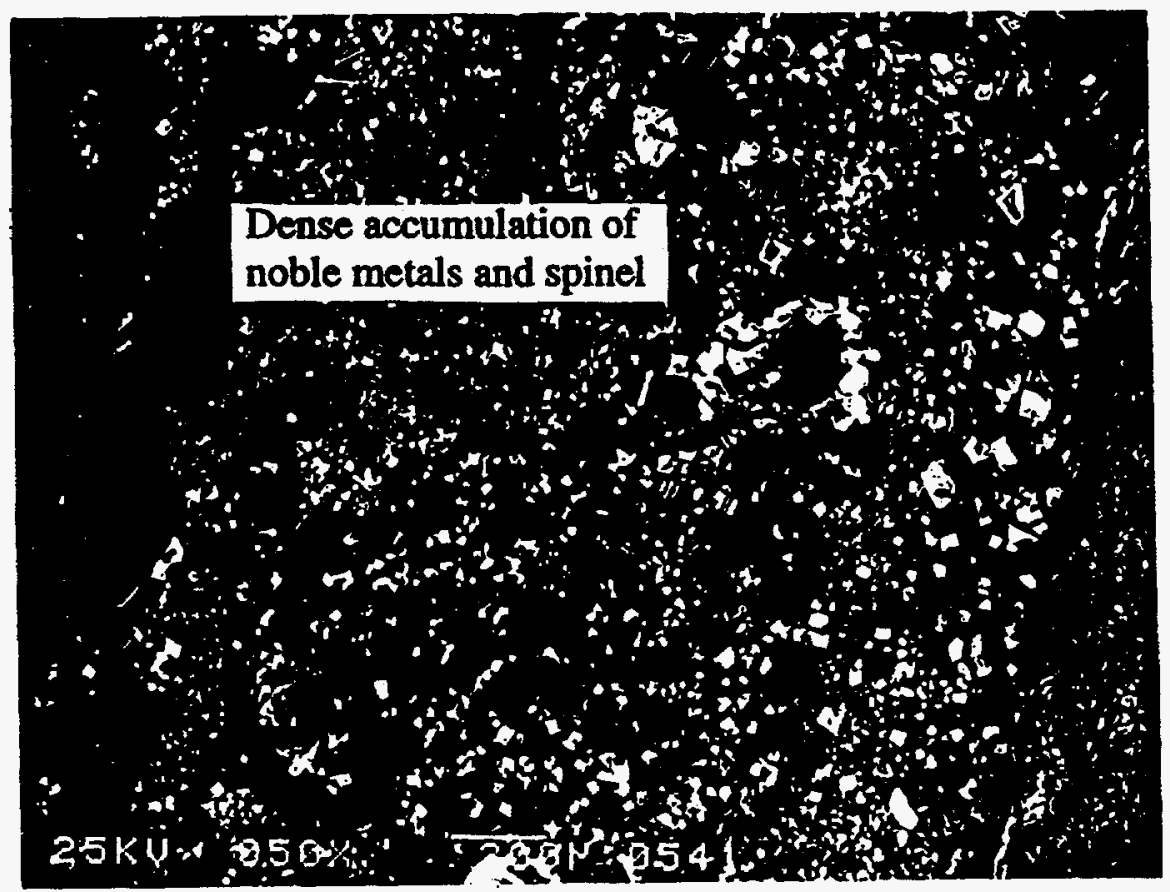

Figure 20. IDMS Melter Floor Sample (H-MELT-0330) taken 12/4/91

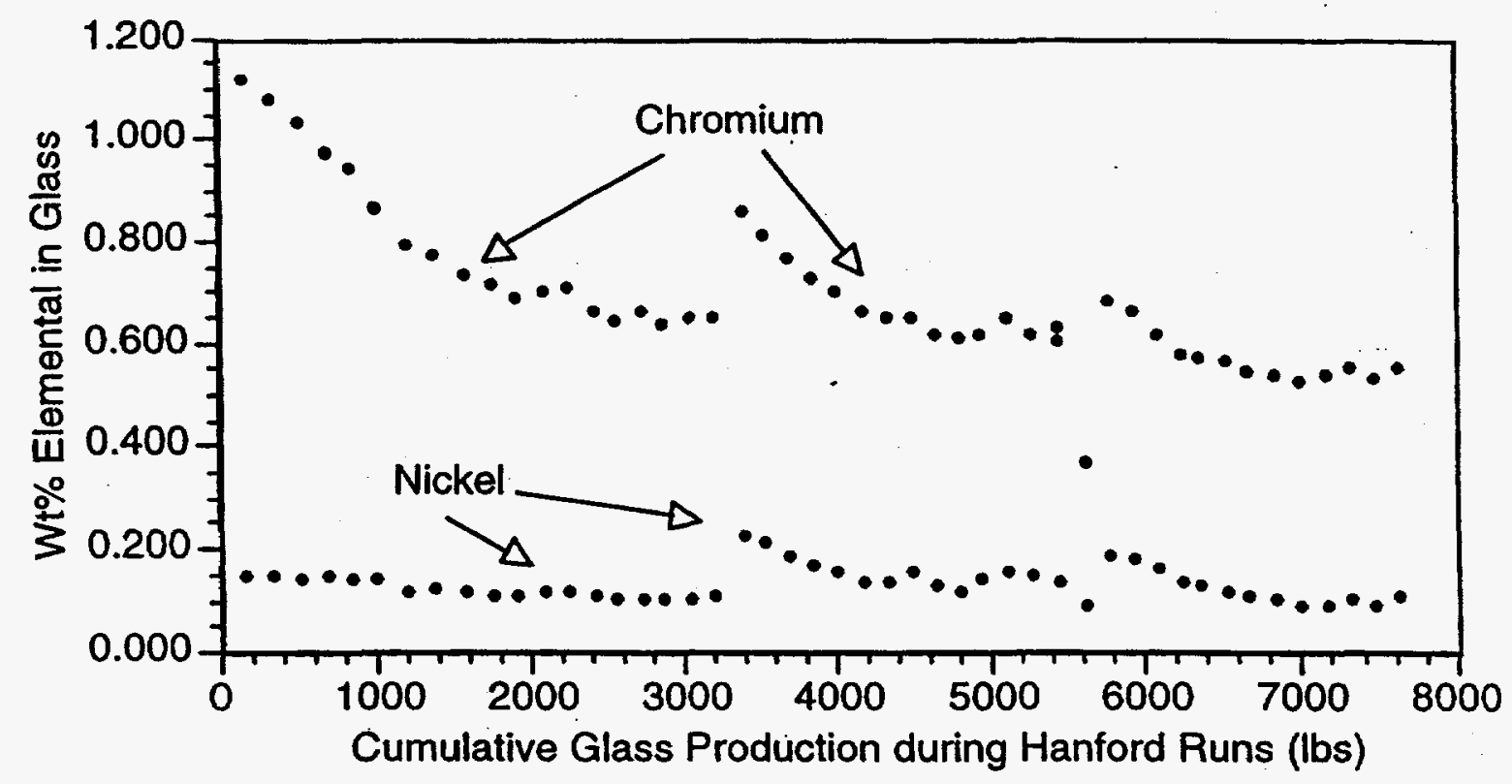

Figure 21. Spinel Components ( $\mathrm{Cr}$ and Ni) in Canistered Glass during Hanford Runs 


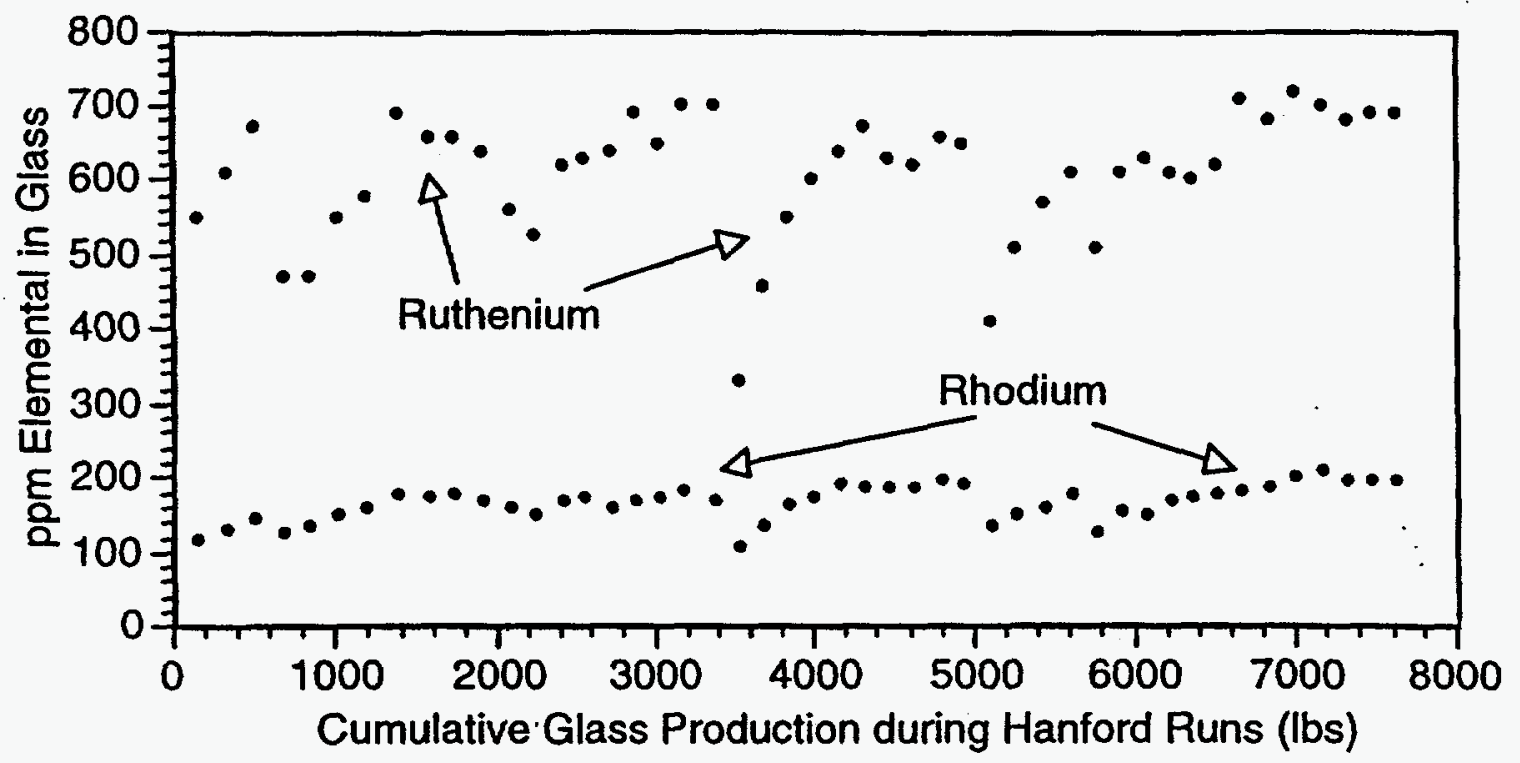

Figure 22. Ruthenium in Canistered Glass during Hanford Runs

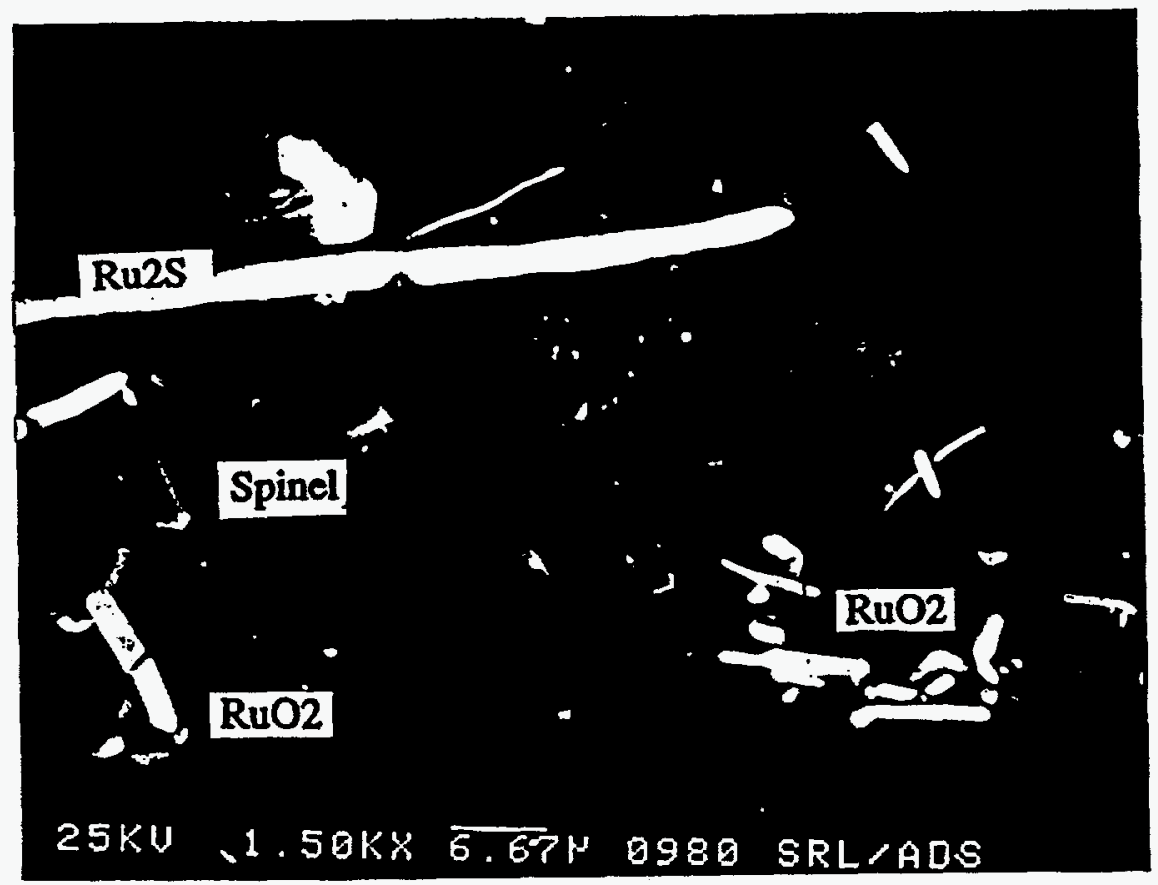

Figure 23. IDMS Melter Floor Sample (I-MELT-5219) taken 3/6/92 


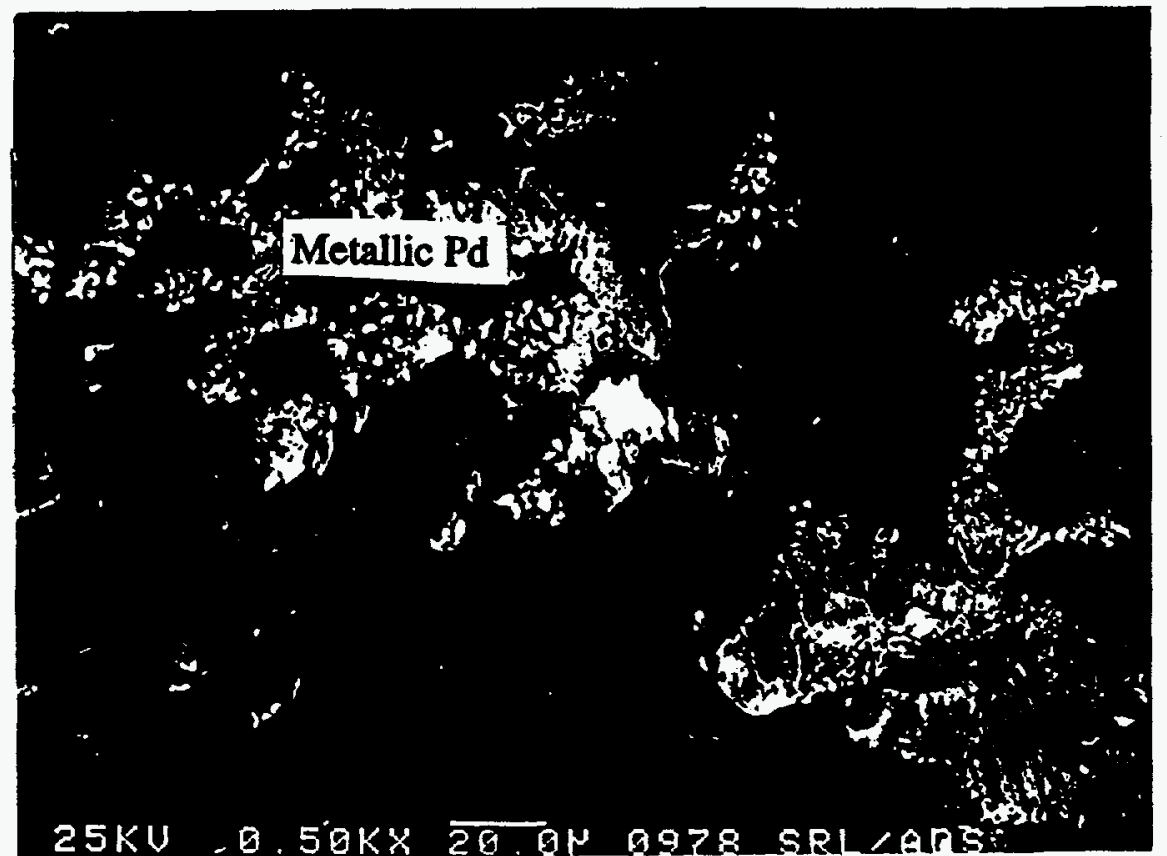

Figure 24. IDMS Melter Floor Sample (I-MELT-5219) taken 3/6/92

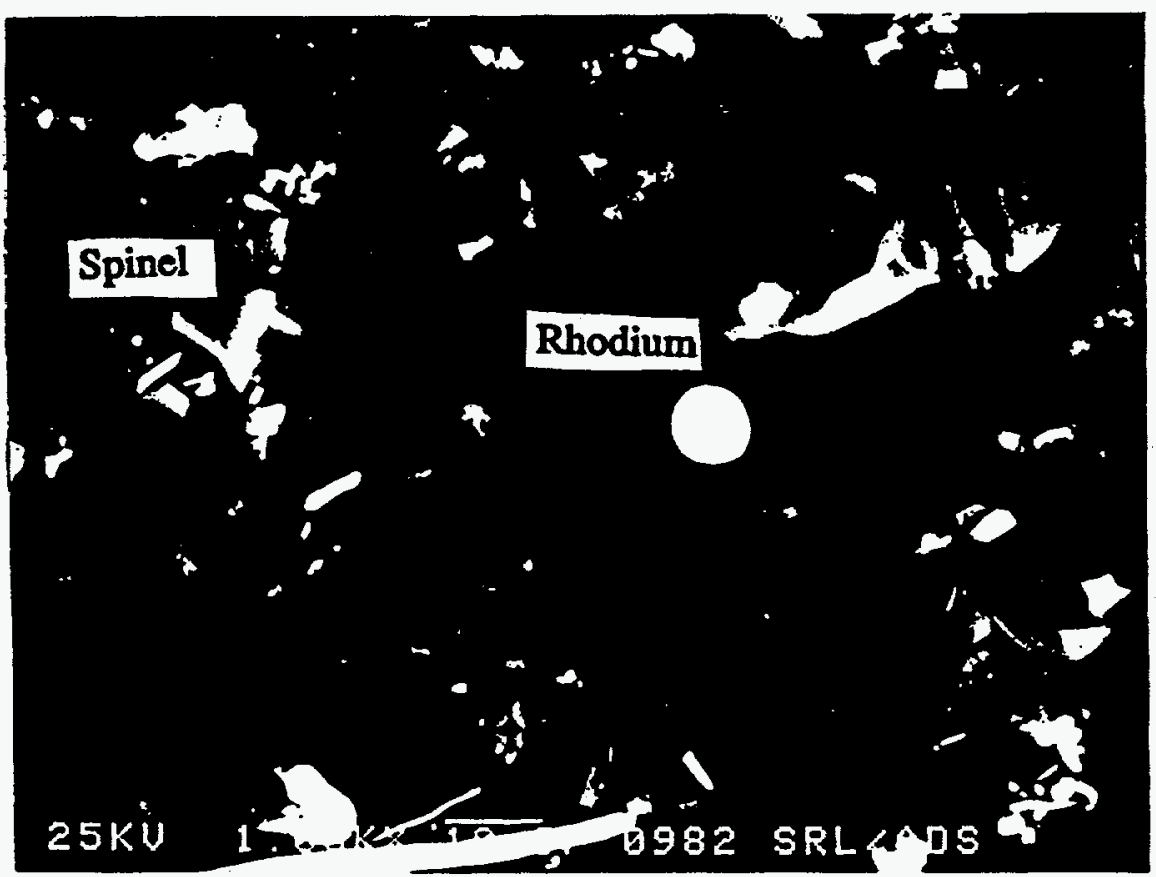

Figure 25. IDMS Melter Floor Sample (I-MELT-5219) taken 3/27/92 


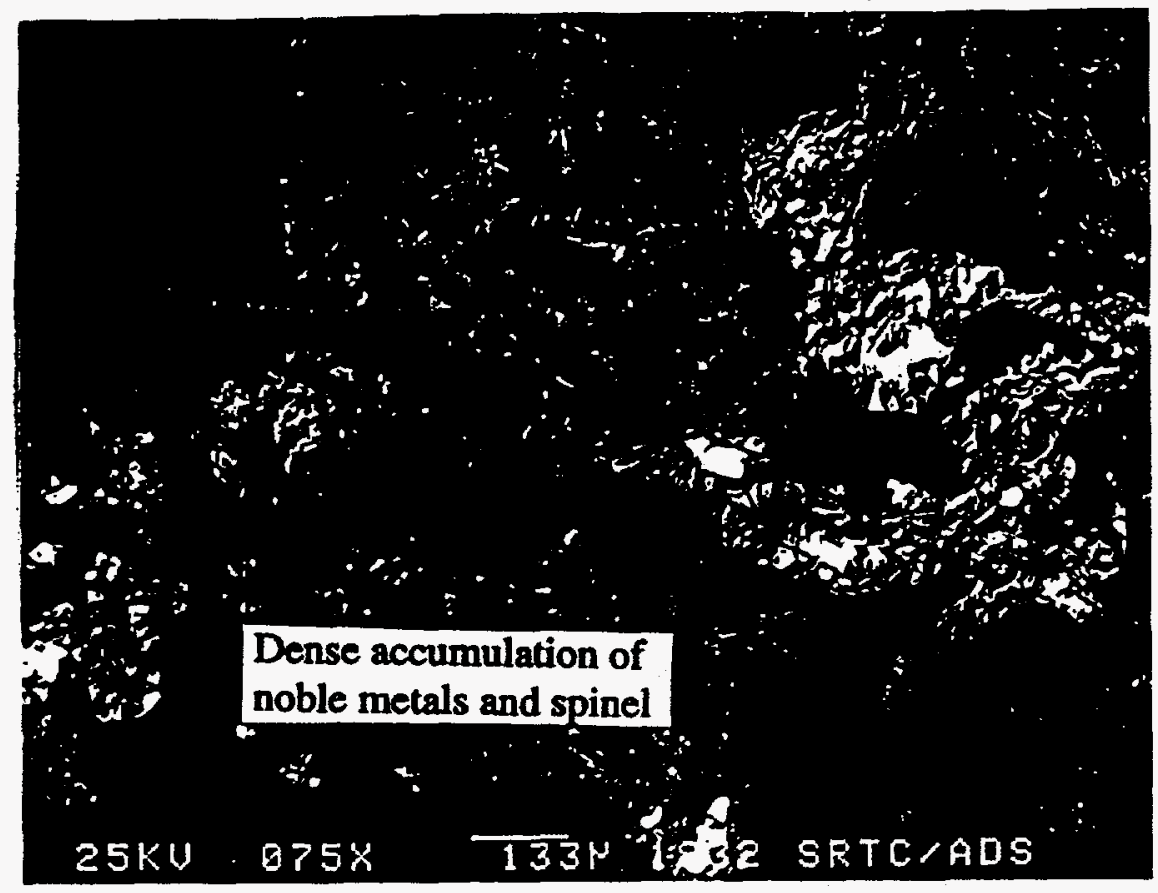

Figure 26. IDMS Melter Floor Sample (I-MELT-5242) taken 3/27/92

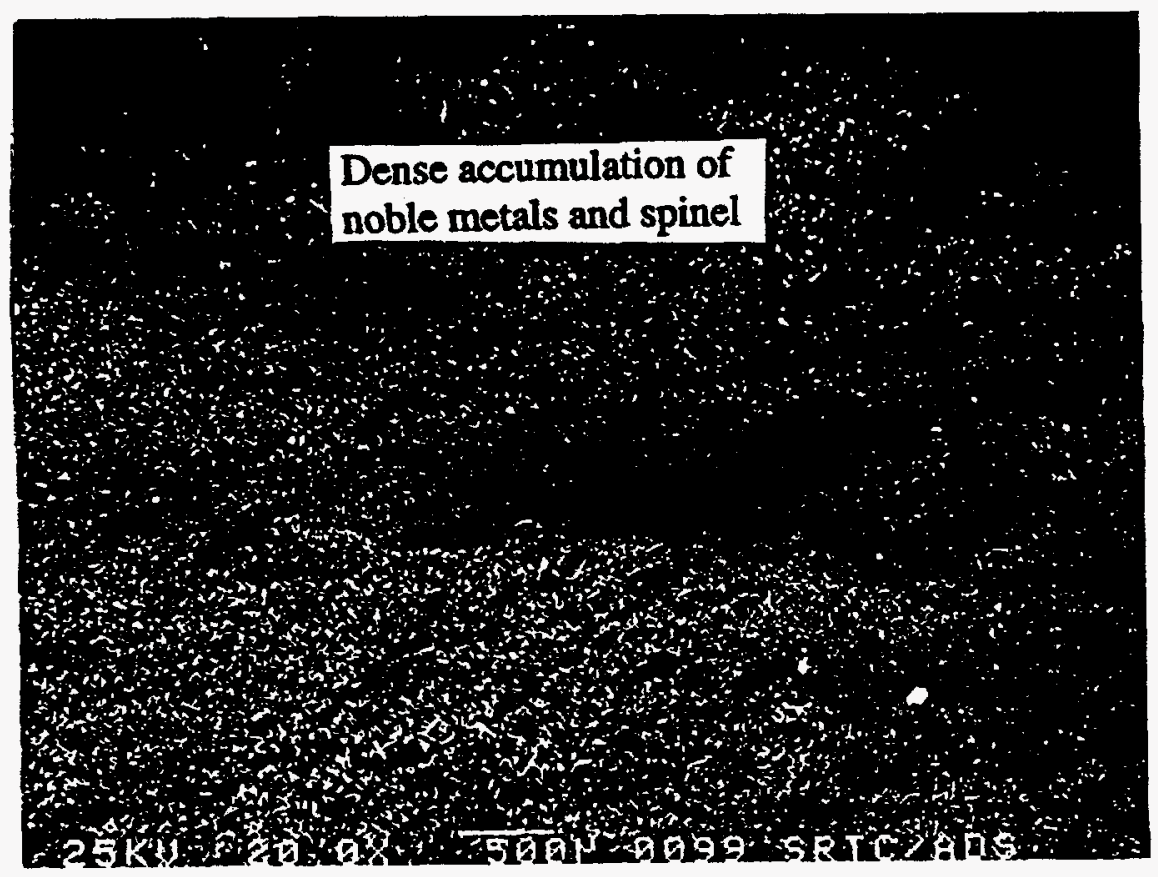

Figure 27. IDMS Melter Floor Sample (I-MELT-5270) taken 4/20/92) 

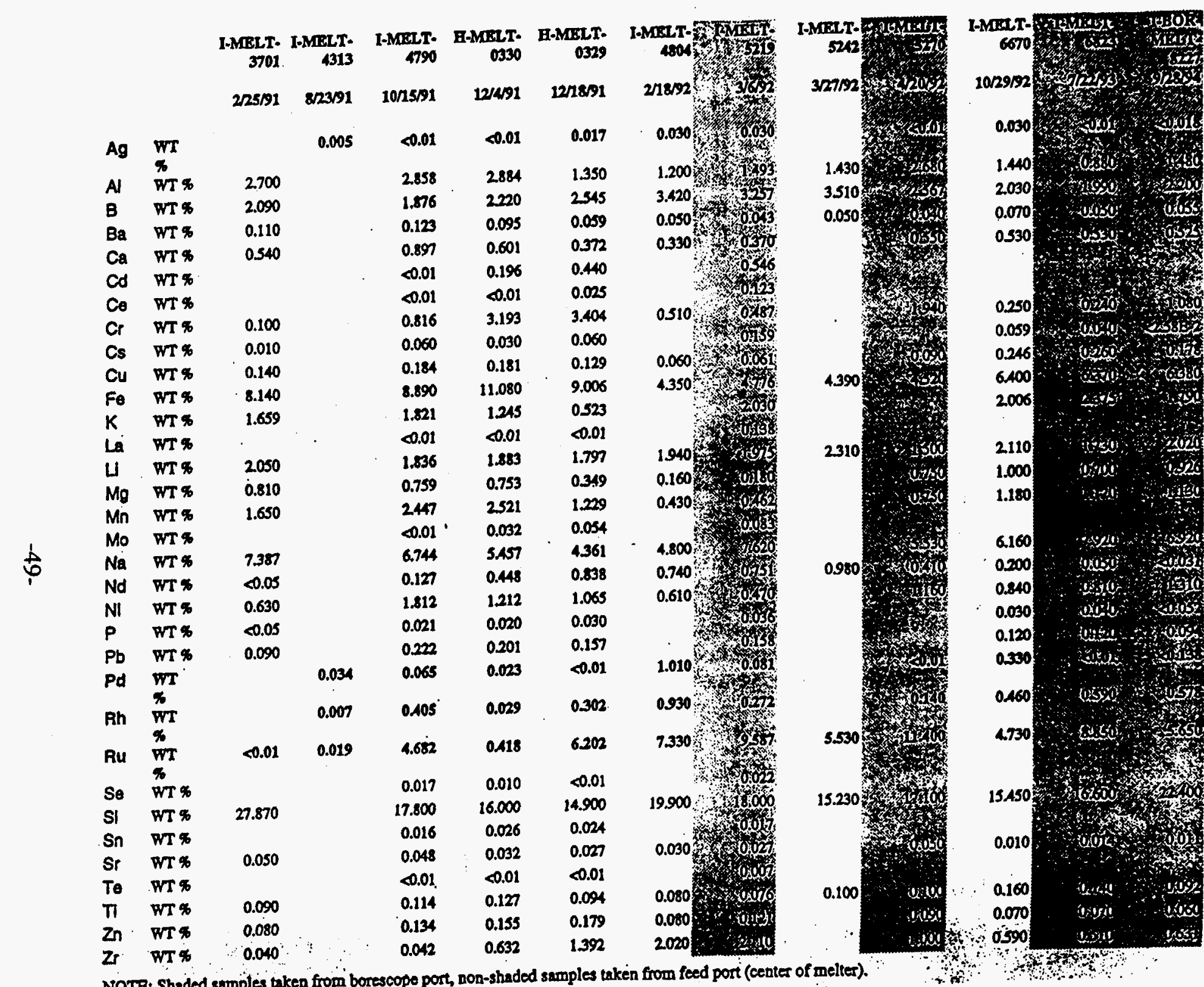

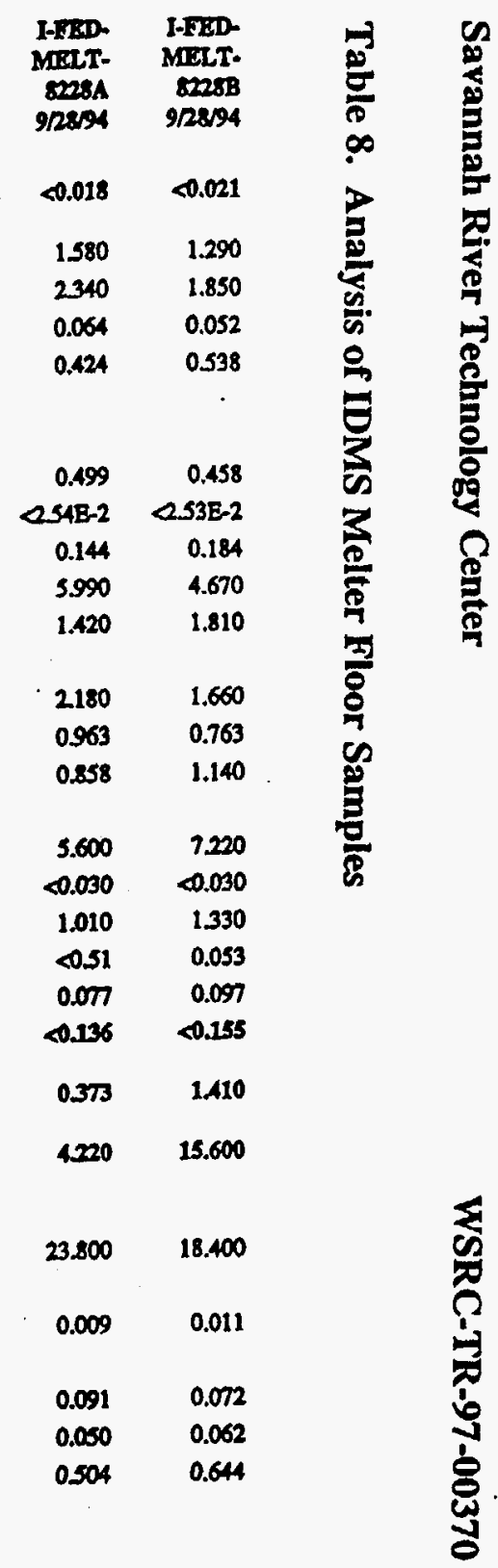




\subsection{Noble Metals Material Balance}

\subsubsection{Analytical Measurements}

In order to complete a meaningful material balance of the noble metals in the melter system (i.e. in order to determine the extent of deposition), accurate analytical measures of the noble metals must be made in the glass product and melter feed slurry. This has proven to be a very challenging task. Several methods have been used to determine the concentration of noble metals in the melter feed slurry and glass. These have included:

- ICP-AES (Aqua Regia Dissolution)

- ICP-AES ( $\mathrm{Na}_{2} \mathrm{O}_{2}$ Fusion/HCl Dissolution)

- ICP-AES (Microwave Acid Dissolution)

- ICP-MS (Aqua Regia Dissolution)

- XRF (X-Ray Florescence)

While ICP-AES and ICP-MS are both excellent analytical tools, their effectiveness is highly dependent upon the type of sample preparation used. The aqua regia and microwave acid procedures proved to be ineffective in the dissolution of the noble metals (especially $\mathrm{RuO}_{2}$ ), and spinels. The sodium peroxide fusion procedure is a very aggressive method and proved to be adequate for getting all components into solution. The results of the ICP-AES ( $\mathrm{Na}_{2} \mathrm{O}_{2} / \mathrm{HCl}$ prep) determinations agreed quite well with those obtained by XRF. However, with both of these analyses, one must carefully analyze a matrix-matched noble metal blank along with the samples of interest. The blank results are then used to correct the raw results from the process samples.

A contract was established with an outside analytical laboratory (Monarch Analytical Laboratories, Inc.). Monarch measured the Ru, Rh, and Pd by ICP-AES for glass samples from glass from every canister filled during the noble metals runs. The analytical solutions were prepared by dissolving the glass matrix in aqua regia and separating the $\mathrm{Ru}, \mathrm{Rh}$, and $\mathrm{Pd}$ by carrier precipitation with copper as the insoluble sulfides. The separated sulfides were then fused with sodium peroxide in zirconium crucibles and dissolved in hydrochloric acid. The resulting solution contained all of the platinum metals but was free of the matrix elements. The solution for tellurium analysis was prepared similarly with excess selenium being used as precipitating agent. Plots of the Monarch analyses versus production time are given in Figures 28 - 30. When one examines the analyses plotted versus production time, it is obvious that the noble metal concentrations increase with continuous feeding, approaching the target concentration. However, the concentration decreased significantly during periods of idling (non-feeding time periods). 


\subsubsection{Material Balances}

Plots of the cumulative amount of noble metals fed to the melter and the cumulative amount exiting the melter with the glass versus glass production are shown in Figures $31-33$ (amount of the metals fed to melter based on melter feed analyses). Figure 31 a shows that approximately $35 \%$ of the ruthenium fed to the melter is retained in the melter as deposits on the melter floor. Similarly, Figure $31 \mathrm{~b}$ shows that approximately $21 \%$ of the rhodium fed to the melter is retained. Figure $32 \mathrm{a}$ suggests that palladium is fully removed from the melter. However, melter floor samples prove that this is not the case. However, except in a few samples, the Pd found on the melter floor has been present as very small $(1 \mu \mathrm{m})$ particles and very dispersed. This, along with other analytical measurements, suggest that $<10 \%$ of the $\mathrm{Pd}$ fed to the melter is retained in the melter. Figures $32 \mathrm{~b}$ and $33 \mathrm{a}$ show mass balance calculations for tellurium and selenium. Since these compounds are quite frequently found alloyed with palladium, one would expect that they would be retained in the melter in a similar extent as Pd. This is the case with Te (at $15 \%$ retained). However, the Monarch analyses suggested that $43 \%$ of the Se which was fed to the melter was retained within the melter. This is not likely. This is more likely a result of the difficulty to analytically measure this compound (especially in the $<25 \mathrm{ppm}$ range). Figure $33 \mathrm{~b}$ shows that, as expected, no silver is retained in the melter as the silver is readily incorporated into the borosilicate glass. No silver or silver compounds have ever been found on the melter floor.

Since the Monarch measurements provide the most extensive analytical data, they have been presented here. However, several analytical methods have been used to measure the noble metals in glass; and, while the analyses may not always agree on the absolute amount of $\mathrm{Ru}$, $\mathrm{Rh}$, etc. in a sample, with each analytical method the tendency is for the noble metals to be retained in the melter in the following relative amounts: $\mathrm{Ru}>\mathrm{Rh}>\mathrm{Pd}>\mathrm{Ag}$.

\subsubsection{Discharge Efficiency}

The discharge efficiency of each of the noble metals, Se, and Te are shown in Figures 34 36. The discharge efficiency is defined as:

$$
\text { Discharge Efficiency }(\%)=\frac{\text { Amount of NM exiting the melter }}{\text { Amount of NM fed to the melter }} \times 100
$$

NOTE: “Amount of NM fed to melter" based on IDMS Melter Feed Tank analyses.

The discharge efficiencies of $\mathrm{Rh}, \mathrm{Pd}$, and $\mathrm{Ag}$, at times, exceed $100 \%$. This can be explained by the fact that these measurements were made when the concentrations of the noble metals, etc. were at "Blend" levels. These lower concentrations are more difficult to measure and are thus more subject to error. Additionally, this calculation assumes that the noble metals in the glass are homogeneously distributed within the glass and therefore may be another source of error. 

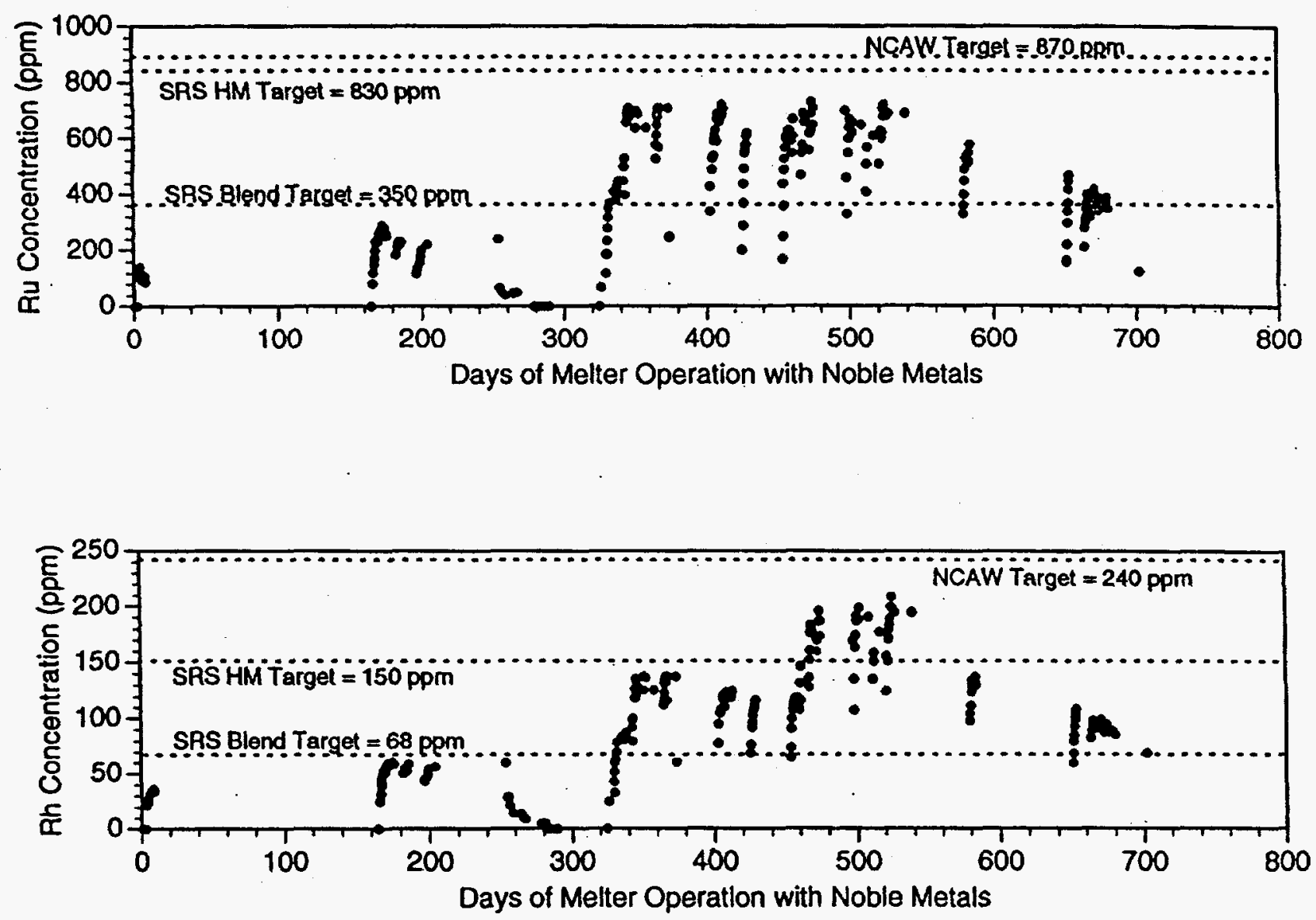

Figure 28. Ru and Rh Analyses with Glass Production 

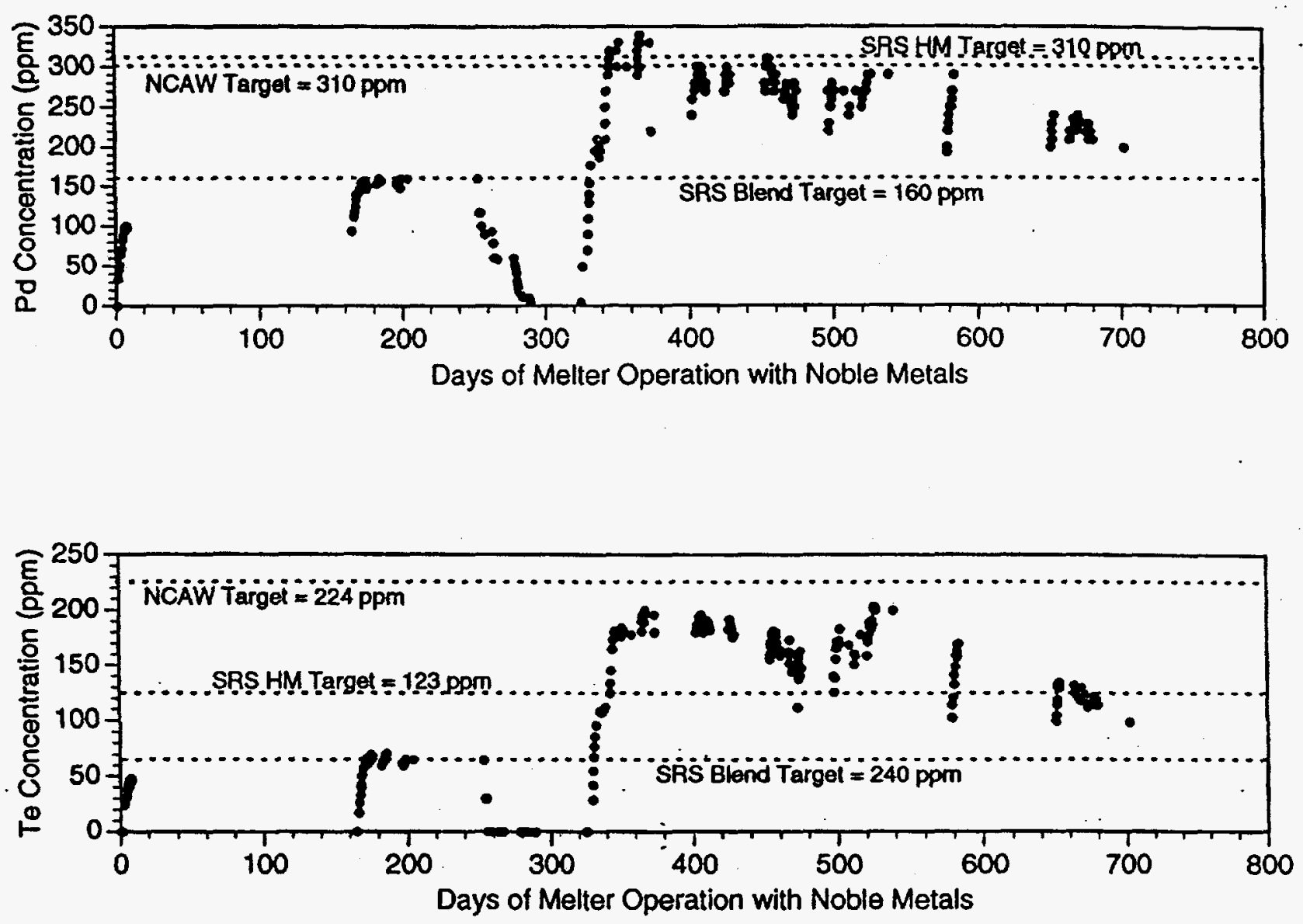

Figure 29. Pd and Te Analyses with Glass Production 

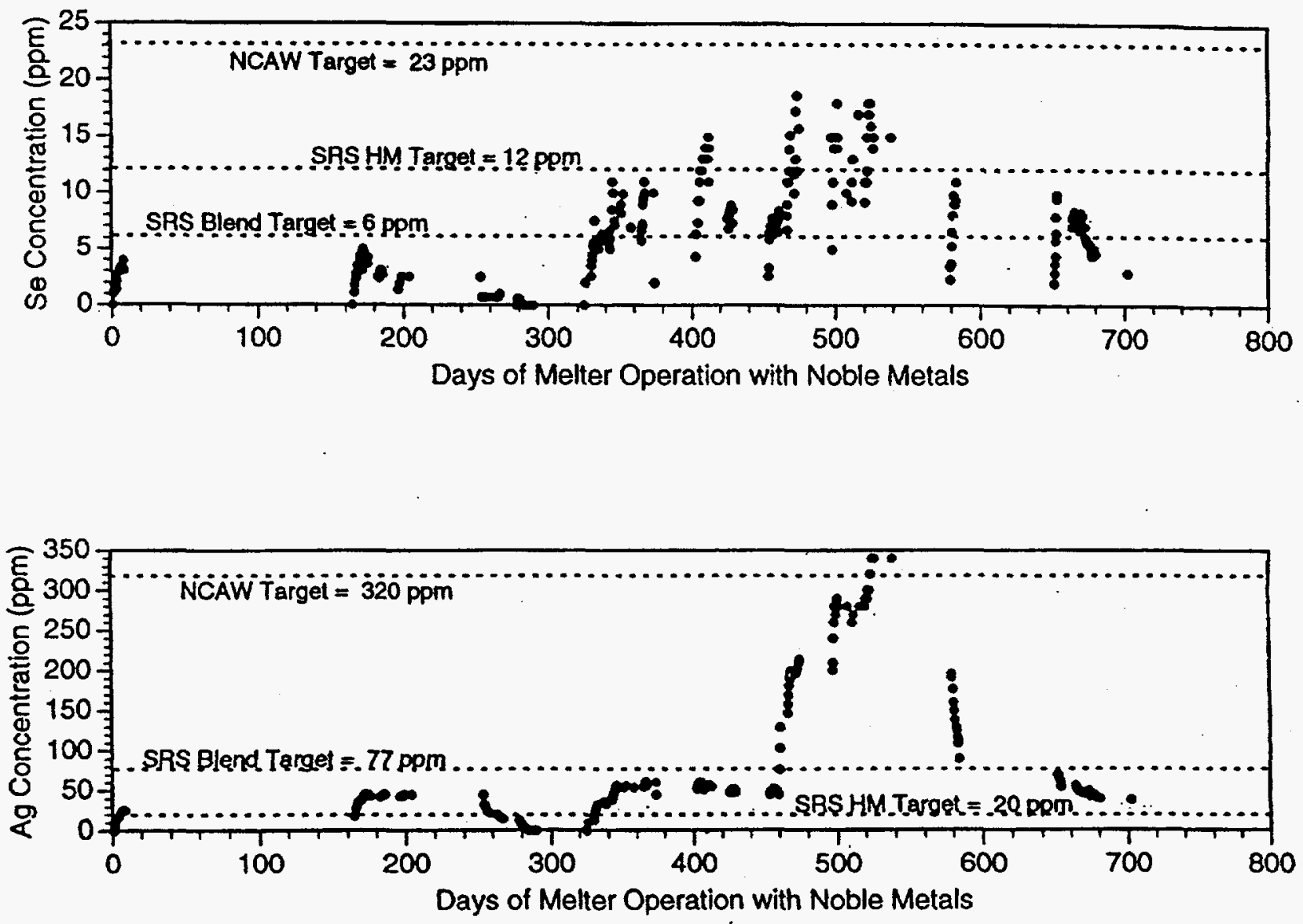

Figure 30. Se and Ag Analyses with Glass Production 

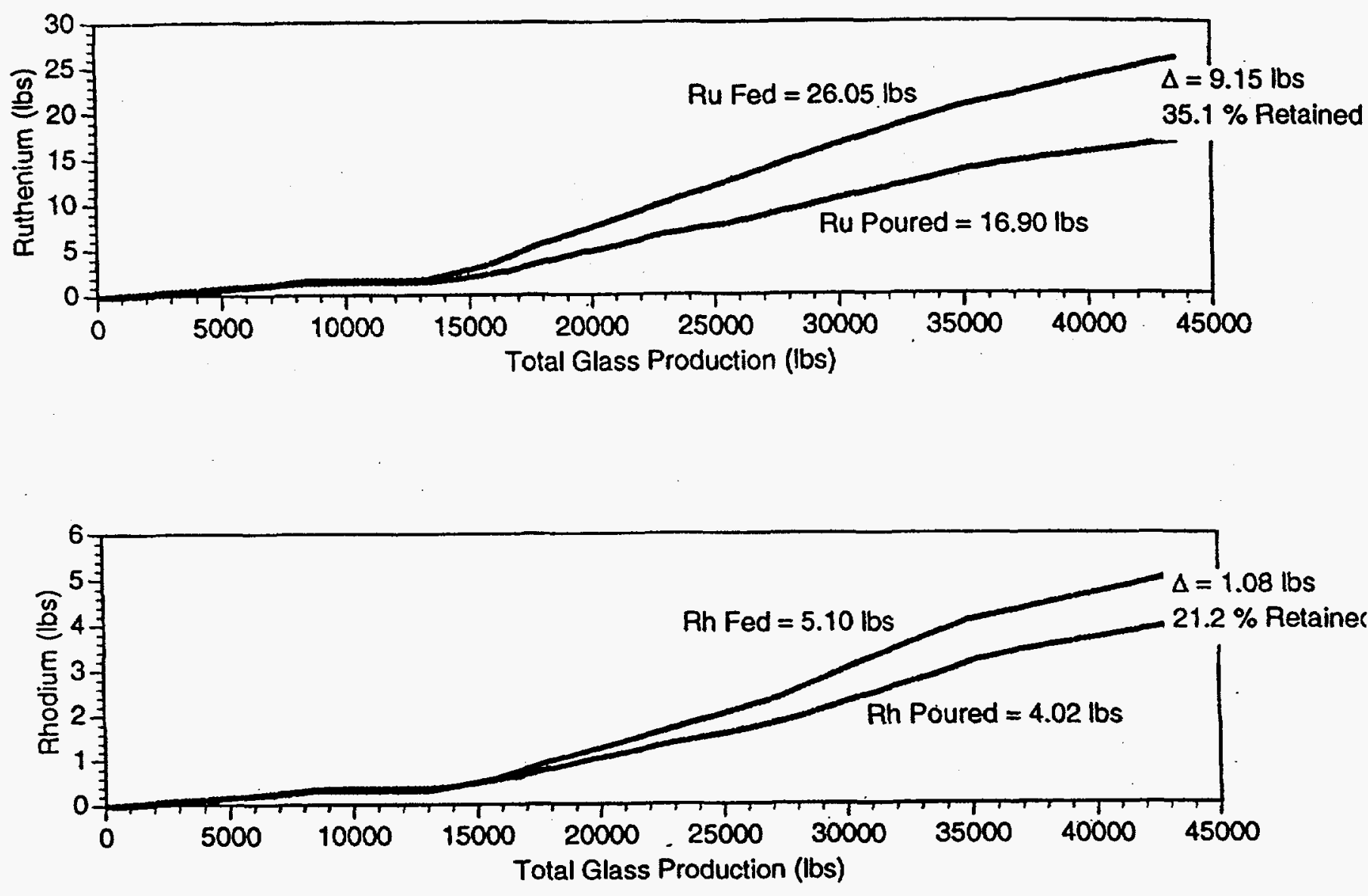

Figure 31. Ru and Rh Overall Material Balance 

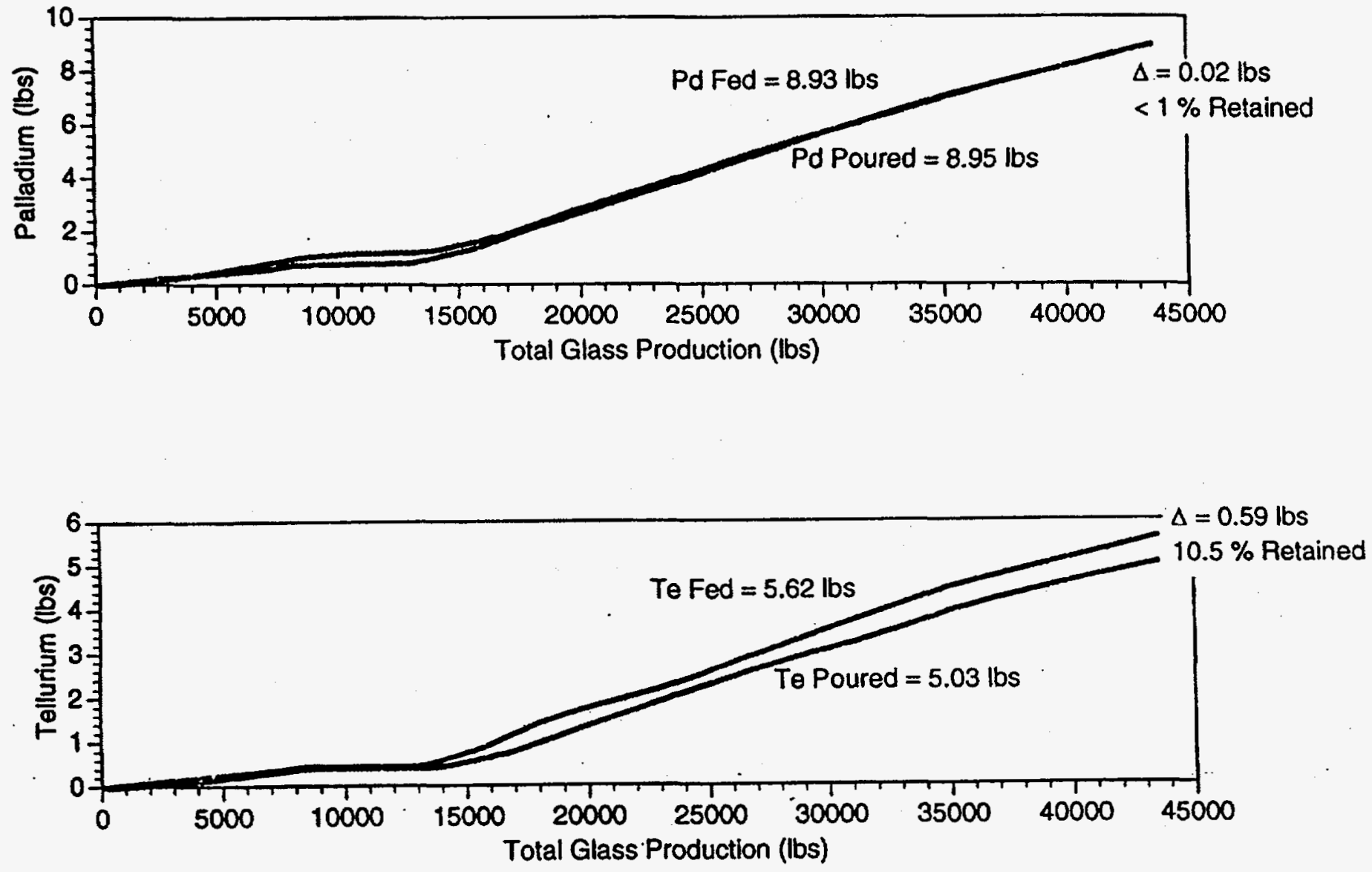

Figure 32. Pd and Te Overall Material Balance 

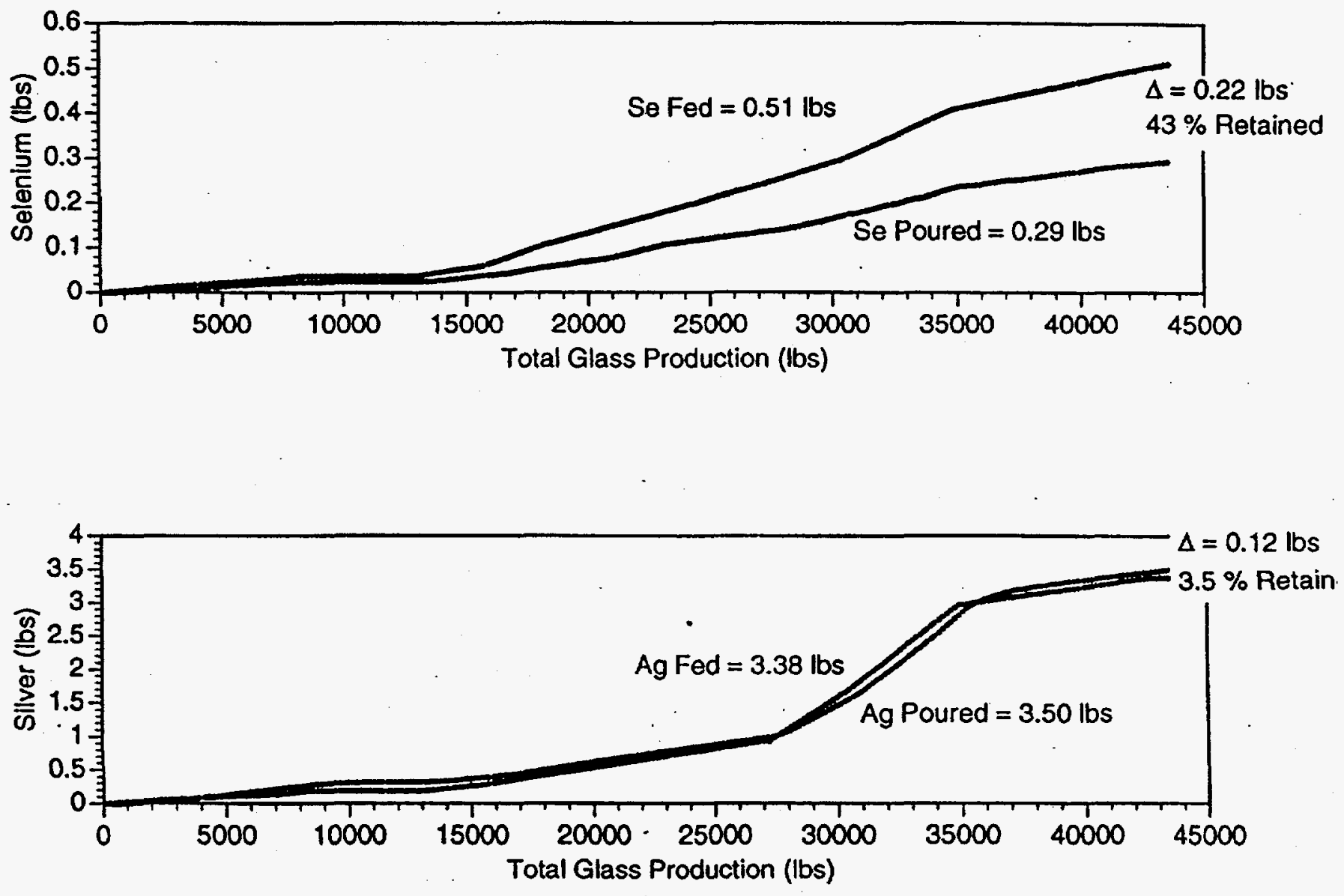

Figure 33. Se and Ag Overall Material Balance 

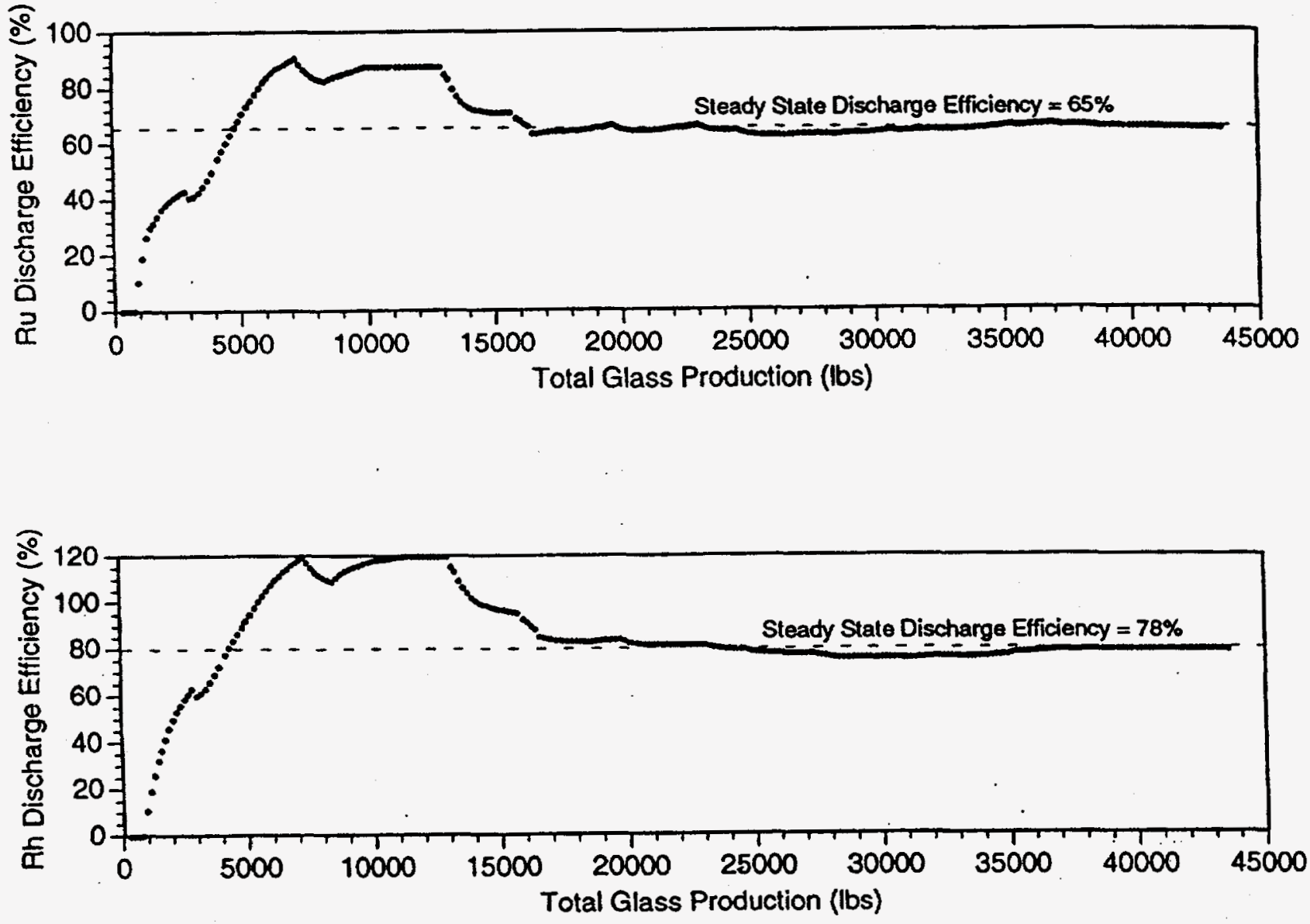

Figure 34. Ru and Rh Discharge Efficiency 

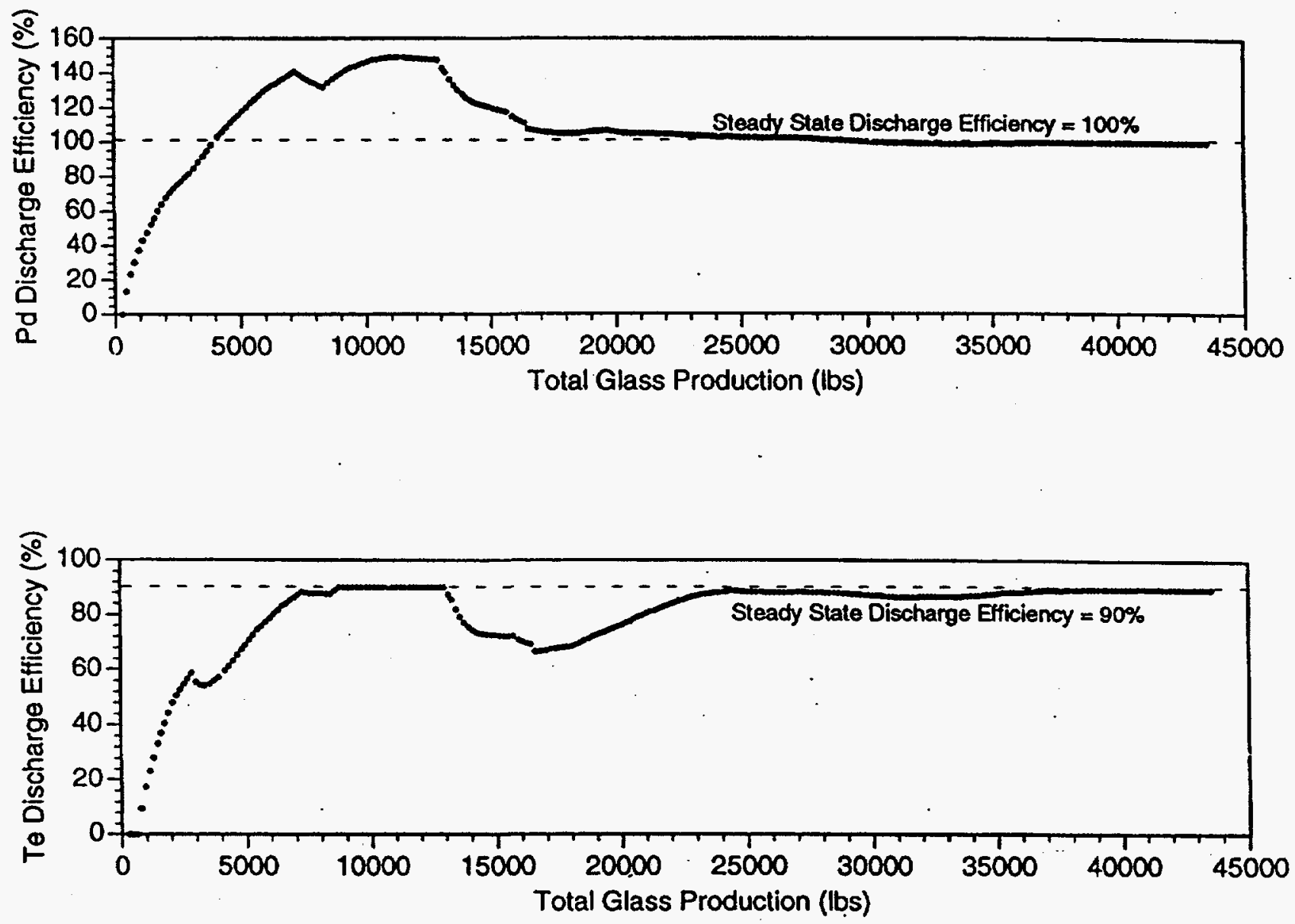

Figure 35. Pd and Te Discharge Efficiency 

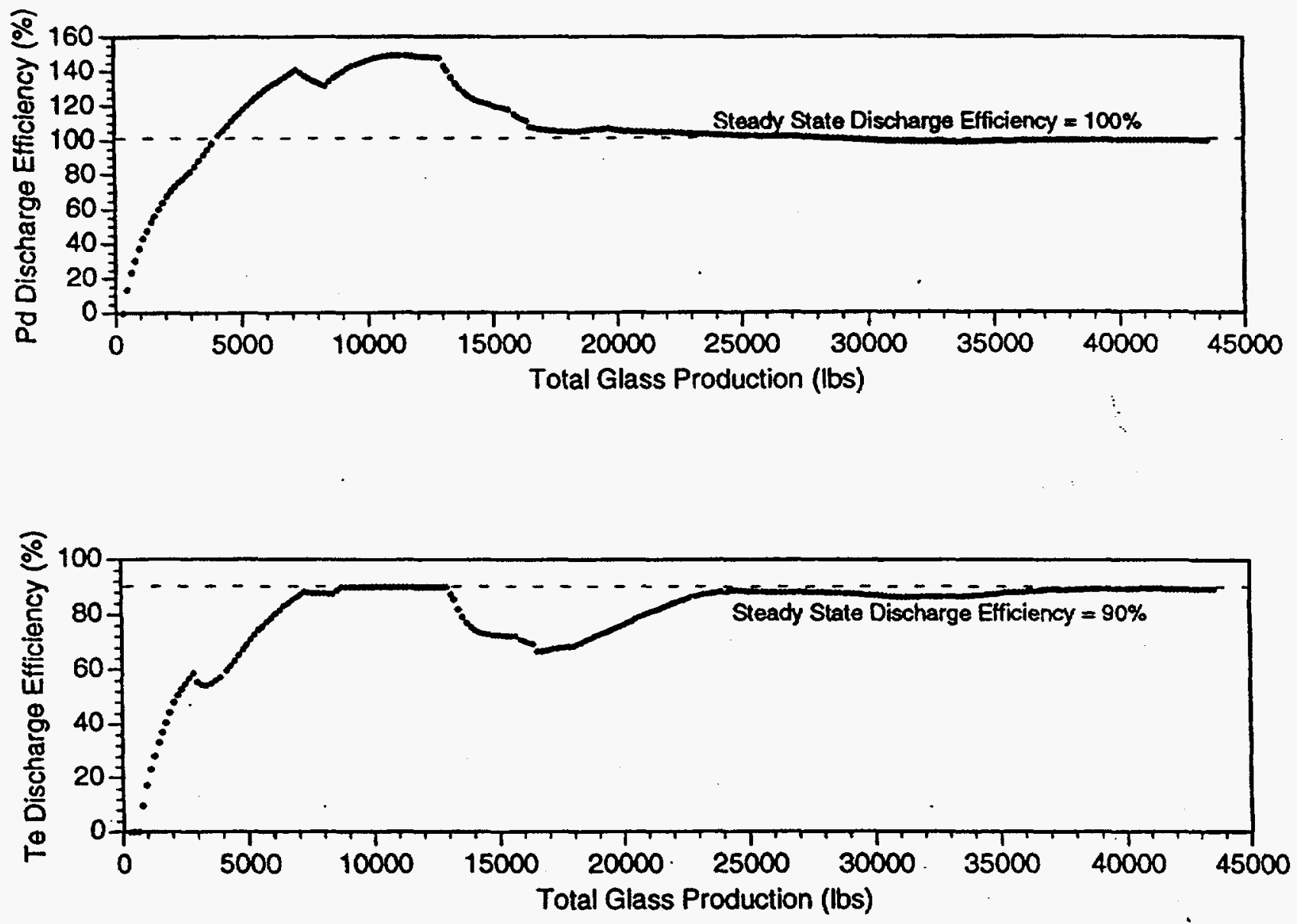

Figure 36. Se and Ag Discharge Efficiency 


\subsection{The Effects of Idling and Natural Convection}

\subsubsection{The Effects of Idling in the IDMS Melter}

Figure 37 shows a plot of cumulative glass production in the IDMS versus operating time from $8 / 90$ to $8 / 92$. This Figure distinguishes between periods of feeding (glass production) and non-feeding (idling). During this two year period, the IDMS melter was fed for 2900 of 17561 hours. This corresponds to an on-line efficiency of approximately $17 \%$ (or was idled for $83 \%$ of the time).

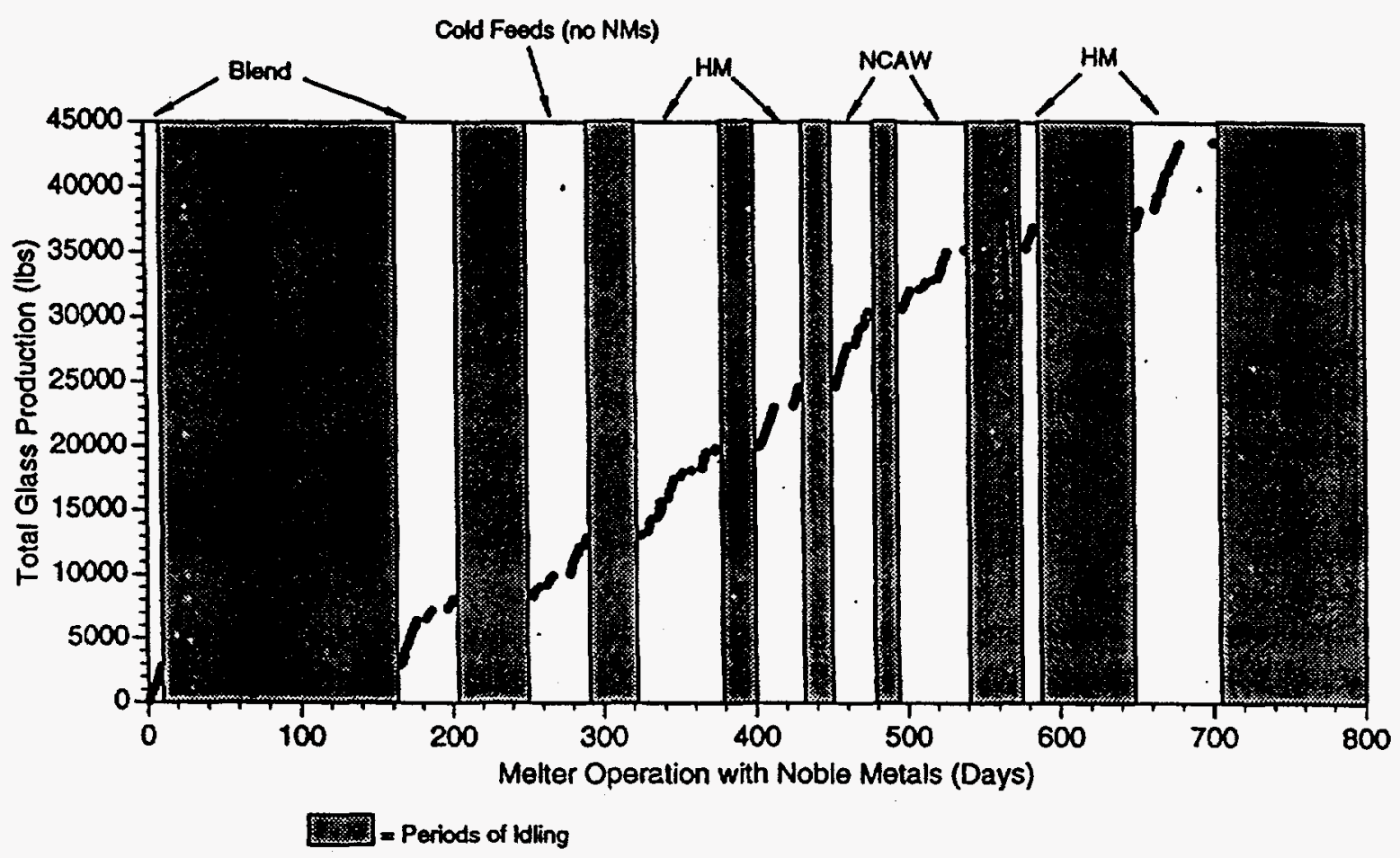

Figure 37. IDMS Cumulative Glass Production

There are several things that contributed to this seemingly large idling time:

- the measurement of hydrogen as a feed preparation offgas product caused a 21 week delay in the operation while safety analyses and facility upgrades were completed.[19]

- the noble metal catalyzed decomposition of formic acid resulted in a corresponding increase in the waste simulant $\mathrm{pH}$ and the release of ammonia gas, another safety concern. [29]

- the relatively high $\mathrm{pH}$ of the melter feed slurries containing noble metals were much more difficult to process because of degraded rheological properties. 
- normal downtime associated with Research and Development activities (evaluation and reporting of data). etc.

It was not known to what extent idling would affect the settling of the melt insolubles in the melter. The Germans had noted that changes in the electrical resistivity in the glass pool were especially obvious during extended periods of idling. It has been suggested that the convective currents that are present during slurry feeding are sufficient to keep the noble metal particles suspended. The suspended noble metals then exit the melter as inclusions in the glass product. However, during periods of idling these convective currents are relatively minor which may allow the particles to settle to the melter floor.[13] In Figures 28 - 30, one can see that the concentrations of the noble metals (esp. $\mathrm{Ru}$ and $\mathrm{Rh}$ ) decreased significantly during periods of idling and sharply increases, toward the target concentration, during periods of continuous feeding. This indicates that most all of the deposition takes place during periods of idling.

The settling of the noble metals, spinels, etc. has been hypothesized to be similar to a typical sedimentation/thickening of a flocculation. Flocculations tend to be complicated structures (as are the melt insolubles) which initially settle in either free or hindered settling. The usual settling equations apply in principle; however, it is not practical to quantitatively apply the settling laws directly because the diameter and shape of a floc is not readily determined.

The changes in concentration of $\mathrm{Ru}$ during periods of idling were determined from the Monarch Analytical data. These concentrations (as $R u(t) / R u(0)$ ) are plotted versus idling time in Figure 38a. One can see that this data follows the same general trend as the hypothetical sedimentation relationship illustrated in Figure $38 \mathrm{~b}$. Thus one can generalize that initially the relative concentration varies linearly until the critical point ( $\mathrm{C}$ in Figure $38 \mathrm{~b}$ ) is reached, and then the rate of change of concentration decreases rapidly until the ultimate concentration is reached. This data then suggests that the $\mathrm{Ru}$ is present in the melt as particles which will and will not easily settle. This ultimate concentration represents the amount of $\mathrm{Ru}$ in the melt that will not easily settle.

From the data in Figure 38a, the critical settling point seems to be reached between 10 and 20 days of idle time. Therefore, the data taken before 20 days was used to generate a leastsquares relationship for relative Ru concentration versus idle time for the IDMS melter. This relationship is shown in Figure 38c. From this information, the linear region is described by:

$$
\frac{[\mathrm{Ru}]_{\mathrm{t}}}{[\mathrm{Ru}]_{0}}=0.9814-0.04713 \mathrm{t} \quad \text { where } \mathrm{t} \text { is idle time in days }
$$

The transition region cannot be described well and thus no regression relationship is provided. However, the ultimate relative concentration appears to be between 0.25 and 0.30 
indicating that approximately 25 to $30 \%$ of the $\mathrm{Ru}$ in the melter is of a size or shape that does not settle easily.

\subsubsection{The Effects of Concentration}

As shown, idling of the melter (periods of non-feeding) severely influences the settling of the noble metals and other glass insolubles to the melter floor. However, the greatest increase in the amount of material on the melter floor occurred in the time period just after the noble metal concentrations in the melter feed were increased from "Blend" levels to "HM" levels even though the idling time between runs was relatively short. The longest period of idling occurred between the feeding of BL1 and BL2 feed materials. However, during this time, only a small amount of material settled to the melter floor.

In the Research Scale Melter (RSM) studies at PNNL, the results suggested that there was a significant nonlinear increase in the amount of noble metal compounds deposited on the melter floor with a 2-fold increase in the nominal noble metal content of the NCAW melter feed simulant. This resulted in a 9-fold increase in the fraction settling. [11] 

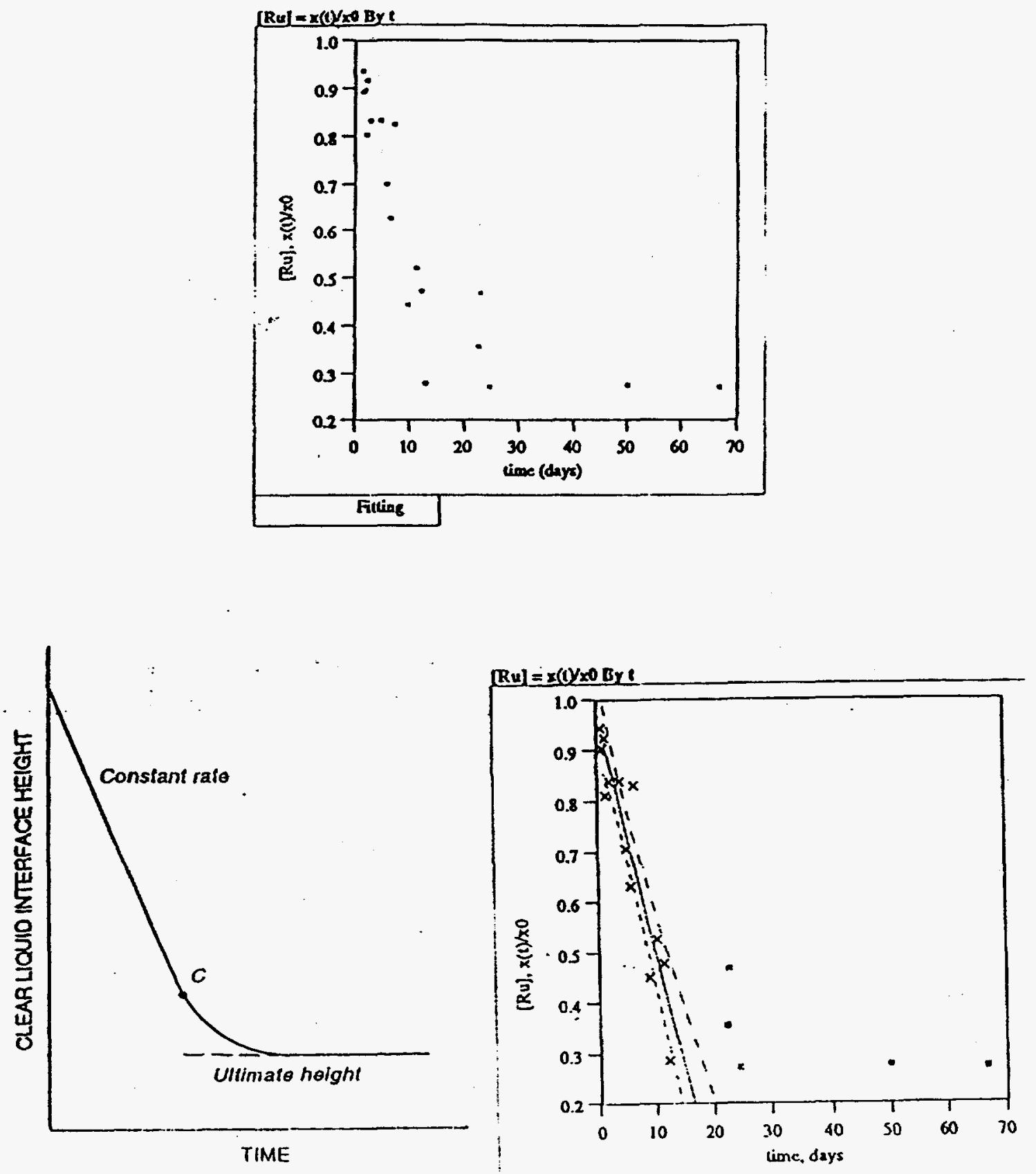

Figure 38. (a) Ruthenium Concentration In IDMS Glass Versus Idling Time, (b) Hypothetical Sedimentation Curve, (c) Linear Relationship between Ru Concentration and Idling Time 


\subsection{Results of the Post IDMS Melter Shutdown Floor Sampling}

After the IDMS melter was shutdown, samples of the material at the bottom of the melter were taken and analyzed. [31] High concentrations of spinel (27 to $66 \mathrm{wt} \%$ ) were found in these samples. In addition, the samples were also highly enriched in $\mathrm{Ru}$ and varied from 0.16 to $7.74 \mathrm{wt} \%$. The range of $\mathrm{Rh}$ was 0.026 to $1.21 \mathrm{wt} \%$, and the range of $\mathrm{Pd}$ was 0.031 to 0.17 wt\%. The Ru present was $\mathrm{RuO}_{2}$. Due to how the samples were taken, it was not possible to quantify the amount of noble metals that had remained in the melter. Table 9 gives the noble metals concentrations of these floor samples.

Table 9. Wt\% Concentration of Spinel and Noble Metals (Ru, Rh, and Pd) from IDMS Floor Samples

\begin{tabular}{|l|c|c|c|c|c|}
\hline Sample ID & $\begin{array}{c}\text { ADS } \\
\text { NUMBER }\end{array}$ & $\begin{array}{c}\text { TREVORITE } \\
\text { Wt\% }\end{array}$ & Ru Wt\% & Rh Wt\% & PD Wt\% \\
\hline & & & & & \\
\hline BLOB-1 & 58577 & 42 & 0.33 & 0.078 & 0.068 \\
\hline BLOB-2 & 58579 & 66 & 1.12 & 0.026 & 0.062 \\
\hline BLOB-3 & 58580 & 33 & 5.37 & 0.069 & 0.041 \\
\hline BLOB-4 & 58581 & 29 & 7.74 & 1.21 & 0.066 \\
\hline BLOB-5 & 58582 & 27 & 5.66 & 1.00 & 0.160 \\
\hline BLOB-6 & 58583 & 51 & 1.19 & 0.210 & 0.083 \\
\hline BLOB-7 & 58584 & 48 & 0.16 & 0.062 & 0.075 \\
\hline BLOB-8 & 58585 & 27 & 0.41 & 0.130 & 0.031 \\
\hline BLOB-9 & 58586 & 36 & 1.60 & 0.39 & 0.14 \\
\hline BLOB-10 & 58587 & 44 & 1.7 & 0.410 & 0.170 \\
\hline
\end{tabular}

\subsection{Effects of Noble Metal Deposition on the Melter}

\subsection{Effects on the Melter Operation}

The electrical characteristics of the IDMS melter are constantly monitored in an effort to judge the effects of the deposition of glass insoluble components. Initially the resistance of the lower melt pool was used as an indication of the accumulation of a conductive layer on the melter floor. However, this measurement is not entirely effective in determining the extent of accumulation of deposits in that each glass composition has a different electrical resistance at a given temperature. Therefore the ratio of the upper melt pool resistance to that of the lower melt pool was monitored as the indication of conductive material on the 
melter floor. In using this measure, any changes in resistance due to differences in glass temperature or composition are normalized. A rise in this ratio would suggest an increase in the amount of conductive material on the melter floor. The resistance of the glass is calculated as follows:

$$
\text { Resis } \mathrm{AB}=\frac{\text { Voltage }_{\mathrm{AB}}}{\text { Current } \mathrm{AB}^{\mathrm{B}}}
$$

and

$$
\text { Resis } \mathrm{CD}=\frac{\text { Voltage } \mathrm{CD}}{\text { Current } \mathrm{CD}}
$$

so that

$$
\text { Resistance Ratio }=\frac{\text { Resis } A B}{\text { ResisCD }}
$$

where $\mathrm{AB}=$ upper electrodes and $\mathrm{CD}=$ lower electrodes

Figures 39 - 45 show various operating parameters of the melter. Figure 39 shows the upper and lower currents of the electrodes. Figure 40 shows the corresponding melt resistivities (as calculated using the above equations). The dotted lines indicated the initial (before the introduction of noble metals) values. Figure 41 shows the upper-to-lower resistance ratio. Again, the dotted line indicates the initial value of the ratio. One can see that the ratio is stable, oscillating from 1.1 to 1.3 until approximately 550 days of operation. The ratio then begins to increase dramatically and has continued upward to $2.3-2.5$. It is interesting to note that the quick increase in the resistance ratio corresponded to a time when melter floor samples revealed a significant increase in the amount of material on the melter floor. Appendix B [32] gives a statistical analysis of the effects of noble metals on the IDMS melter upper-to-lower resistance ratio from for all the noble metals runs from Blend-1 to HWVP-2. (total of 17,620 grams of noble metals added). The conclusion of the analysis was that there was a statistically significant ( $95 \%$ confidence level) increase in this ratio as the addition of noble metals was continued in the melter. Figure 42 shows the upper melt temperature and the upper electrode pair current requirement while Figure 43 shows the upper melt temperature with the glass pool resistivity. Figure 44, similarly, shows the lower glass pool temperature and the lower electrode pair current requirement while Figure 45 shows the lower glass pool temperature with the lower glass pool resistivity. One can see that the resistivity of the lower glass pool has decreased, increasing the current requirement to the point that a current limit (set at $600 \mathrm{amps}$ ) prevented the melter from being operated in the desired temperature range $\left(1100-1150^{\circ} \mathrm{C}\right)$. The current limit has now been increased and a current of 650 amps was required to maintain the lower glass pool at approximately $1070^{\circ} \mathrm{C}$ (glass required to be above liquidus temperature limit set at $1050^{\circ} \mathrm{C}$. This current exceeded the design current density ( $6.1 \mathrm{amps} / \mathrm{in}^{2}$ versus the design value of $\left.5.0 \mathrm{amps} / \mathrm{in}^{2}\right)$, however it was not deemed to place the lower electrodes at any risk. 


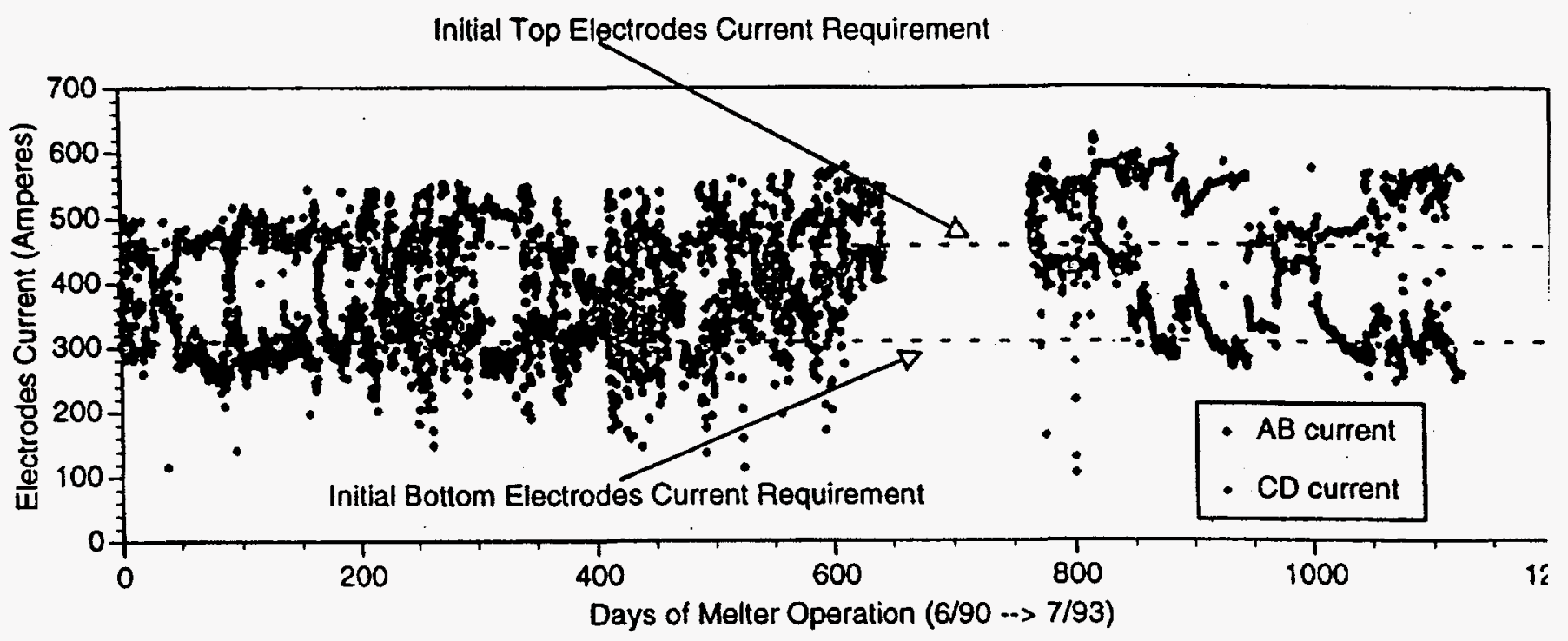

Figure 39. IDMS Melter Upper and Lower Electrode Currents (Amperes)

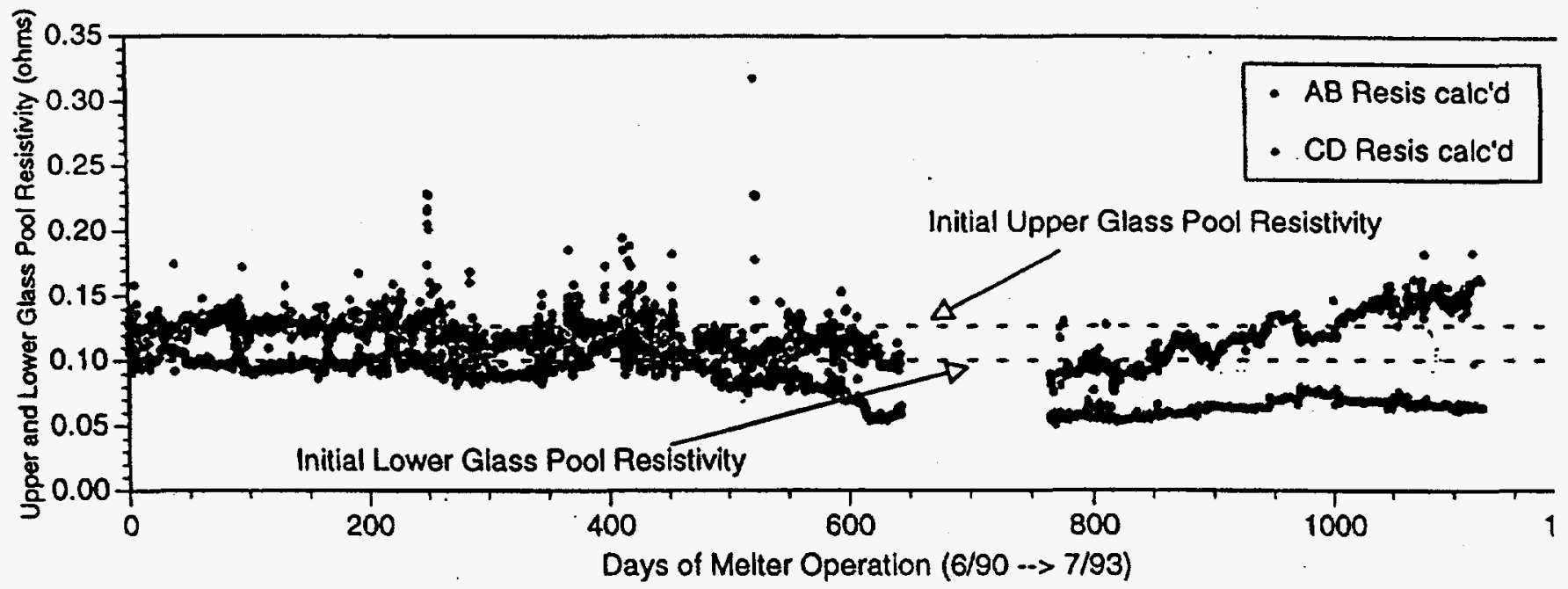

Figure 40. IDMS Melter Upper and Lower Melter Resistivities (Ohms) 


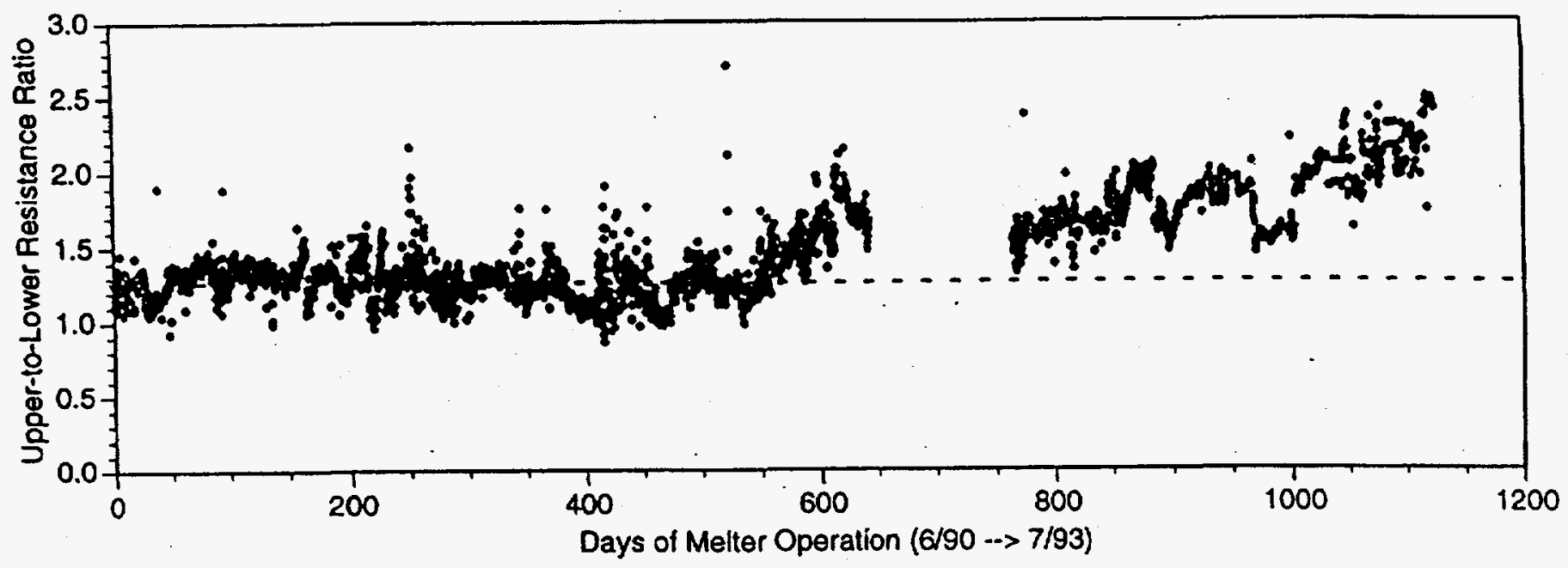

Figure 41. IDMS Upper-to-Lower Resistivity Ratio

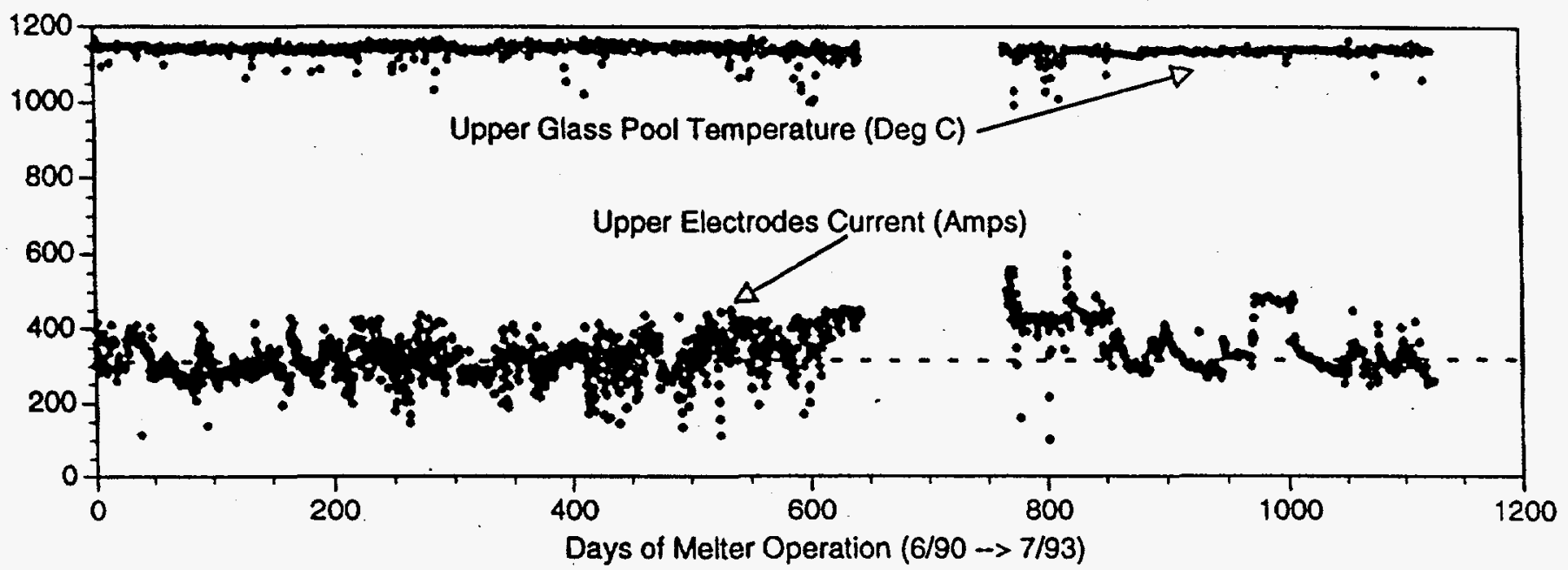

Figure 42. IDMS Melter Upper Melt Pool Temperature $\left({ }^{\circ} \mathrm{C}\right)$ and Upper Electrode Current 


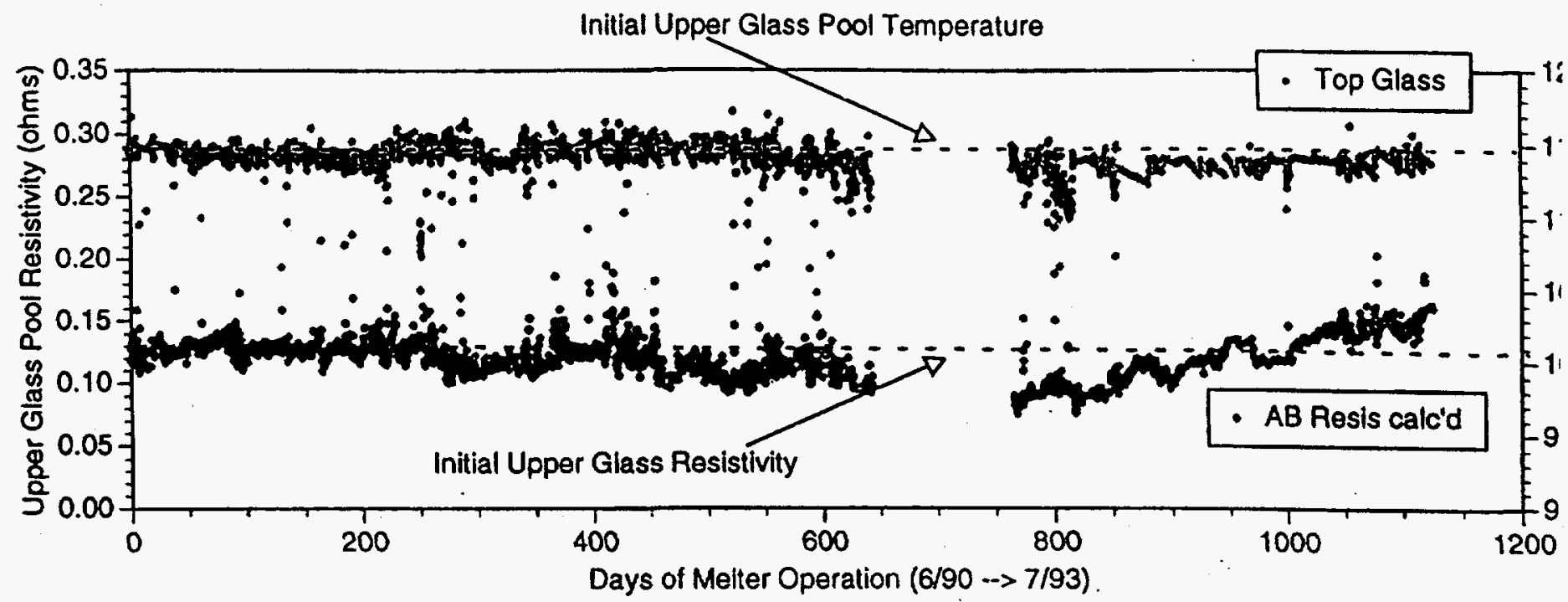

Figure 43. IDMS Melter Upper Melt Pool Temperature $\left({ }^{\circ} \mathrm{C}\right)$ and Upper Melter Pool Resistivity (Ohms)

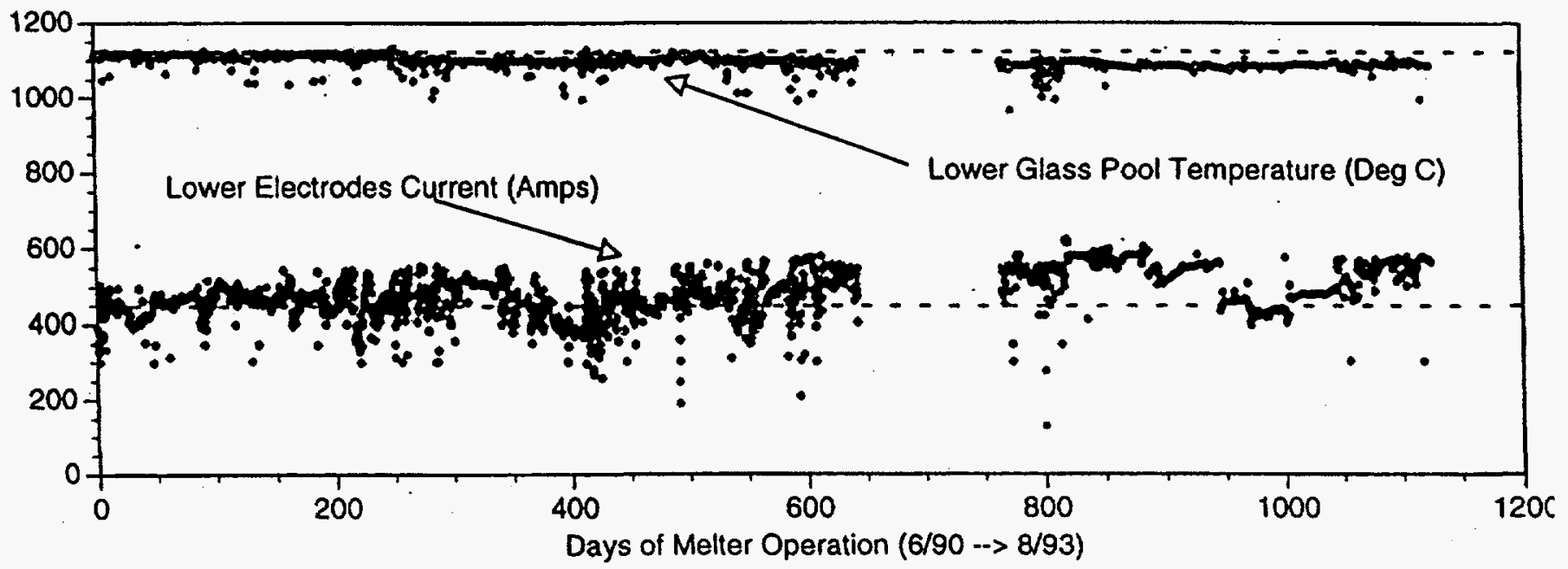

Figure 44. IDMS Melter Lower Melt Pool $\left({ }^{\circ} \mathrm{C}\right)$ and Lower Electrode Current 


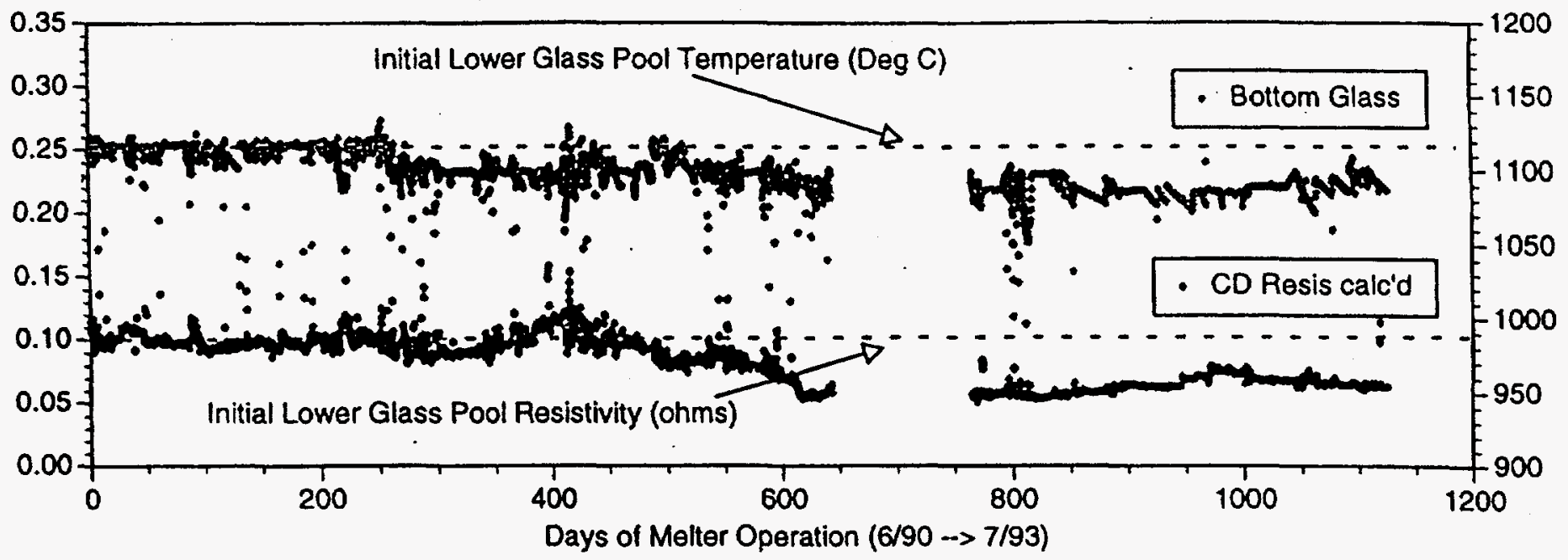

Figure 45. IDMS Melter Lower Melt Pool Temperature $\left({ }^{\circ} \mathrm{C}\right)$ and Lower Melter Pool Resistivity (Ohms)

\subsection{Results of the Melter Inspection}

Approximately two inches of material was lost from the bottom face of the lower electrodes, and the electrodes were very rounded in this area. Mechanisms considered for this are all associated with noble metals deposits; 1) low viscosity glass at hot spot near the junction of the electrodes and the glass could have accelerated wear, 2) high electrical current densities could have accelerated oxidation and electrochemical attack of the electrodes, 3) alloying of the electrodes at the surface with the noble metals Se or Te could have adversely affected the Inconel's ability to develop a passive corrosion inhibiting surface layer, and 4) localized overheating could have caused localized electrode melting.

The upper electrodes faces were also heavily worn, especially at the ends. The extent of the attack was proportionally higher in this melter than in other SRTC melter that had operated for comparable times. The electrodes were still functional.

The most likely cause of the high attack at the bottom of the electrodes is a combination of mechanisms 1 and 2. The general wear pattern is consistent with attack in regions of high current density, which adversely affects electrochemical corrosion rates. High current densities can also be expected to produce local high temperature regions, especially in 
normally stagnant areas such as under the bottom electrodes. There was no direct indication of electrode melting which has been seen in smaller melters and which generally produces a melter short.

Noble metal alloying and enhanced corrosion is unlikely to have been an effect since the thermowell was examined in detail and this mechanism was not observed. However, it is possible that the combination of noble metals and the electrical currents at the electrode faces resulted in such an effect. Detailed metaliurgical examination of the electrode would be necessary to determine the actual mechanism. 
- This page left intentionally blank - 


\subsection{Implications for the DWPF Melter Operation}

Since the IDMS melter continued to operate in spite of damage, it is difficult to predict the maximum lifetime of the DWPF melter based on the operational experience of the IDMS melter. However, assuming the DWPF melter will withstand the same conditions to which the IDMS melter has been exposed, estimates of the minimum lifetime have been made.

There are several caveats which should be considered when interpreting these estimations. Firstly, the IDMS melter was subjected to numerous idling periods in excess of 20 days. As stated above, approximately $70 \%$ of the noble metals in the melter will settle to the floor during this short idling period.

\section{IDMS Production}

1 IDMS glass with HM or NCAW Noble Metals

2- IDMS glass with Blend Noble Metals

3- Max IDMS glass capacity

4- Number of melter HM turnovers (1/3)

5- Number of melter Blend turnovers (2/3)

\section{Equivalent DWPF Production}

6- Max DWPF glass capacity

7- 38 DWPF Melter turnovers (6 $\times 38$ turnovers)

8- DWPF Melter turnovers (6 $\times 8$ turnovers)

9- DWPF $100 \%$ production rate

10- Target minimum nominal operating time, 2 years@70\%.

11- Nominal melter turnovers in 511 days

Equivalent DWPF HM Operating Time

12- Hm sludge Ru content

13- Equivalent HM operating time (( $7 / 9) / 24 \mathrm{hrs}$ per day) Equivalent DWPF Blend Operating Time

14- Blend sludge $R u$ content

15- Equivalent Blend operating time ((8/9)/24 hrs per day)

Equivalent Combined Blend Operating Time

16- Equivalent combined Blend operating time $(13+15)$
$40,300 \mathrm{lbs}$

8,346 lbs

$1,063 \mathrm{lbs}$

38 turnovers

8 tumovers

$13,136 \mathrm{lbs}$

$499,168 \mathrm{lbs}$

$105,088 \mathrm{lbs}$

$228 \mathrm{lbs} / \mathrm{hr}$

511 days

213 turnovers

0.217 wt\%

91 days

$0.100 w t \%$

19 days

110 days

Equivalent Combined Tank 51 Operating Time

17- Tank 51 Ru content [30]

$0.005 \mathrm{wt} \%$

18- Equiv. Tank 51 operating time $(((12 \times 13)+(14 \times 15)) / 17) \quad 4,329$ days

NOTE: bold numbers in calculations shown [as given in ()'s] show line items used 
Recommendation: Based on IDMS data, the settling of the noble metals appears to be much less during periods of feeding and pouring. This impact, however, may be less in the DWPF Melter due to its larger inner diameter. Therefore, the DWPF should avoid periods of idling when operating with melter feeds containing noble metals. A few extended outages appear preferable to several short period outages; thus when outages must be scheduled, for maintenance, etc., all necessary work should be completed within the extended outage in order to avoid short term outages later.

Secondly, this estimation assumes that the noble metals settle linearly with concentration. This is most likely not the case. In tests conducted at PNNL, it was observed that the settling of the noble metals increased nonlinearly with a 2-fold increase in the noble metal content over the nominal NCAW levels. Therefore, the amount of noble metals settling to the floor while feeding "Blend" melter feed will be much higher than that seen with the existing Tank 51 batch 1a sludge. Still more rapid changes can be expected if HM sludge noble metal concentrations are fed to the DWPF.

The first DWPF melter has not experienced any operational problems associated with noble metals deposition to date. However, because of uncertainties in the blending of Tank Farm wastes, it is difficult to predict a minimum lifetime for subsequent sludge batches.

Recommendation: Tank Farm blending strategies should consider the content of the noble metals in the respective waste tanks. The wastes could be blended such that the noble metal contents are evenly distributed and have a content no greater than that predicted for "Blend-type" sludge ( $\mathrm{Ru}$ about $0.1 \mathrm{wt} \%$ of the dried sludge solids to the DWPF). This is advantageous not only in the maximization of the DWPF melter life but also in the minimizing of hydrogen production the Chemical Processing Cell (CPC). Alternatively, delaying operations with high concentrations of noble metals (HM sludge) to outlying years until possible modifications can be made to subsequent DWPF melters to make them less susceptible to noble metals deposition problems could be done as well.

An inspection of the IDMS melter after shutdown showed that the bottom electrodes had sustained appreciable damage on their lower portions. The Inconel $690 @$ drain valve and pipe also had extensive corrosion This damage was probably due to a high current density caused by noble metals partially shorting out the melter.

Recommendation: The bottom electrodes of the IDMS melter should be removed from the melter and characterized for change in dimensions and mode of metallurgical attack. Samples previously removed from the bottom of the melter should be measured for viscosity and electrical conductivity. Any deposits remaining under the electrodes should be removed for physical characterization (viscosity, electrical conductivity) and chemical composition. 
The ratio of upper-to-lower glass pool resistance has proved to be an effective measure in indicating the accumulation of noble metals on the floor of the IDMS melter. This ratio continue to rise during the noble metals runs, thereby showing that the bottom electrode circuit resistance was being lowered. This implied that a conductive layer of material (noble metals) was forming on the melter bottom. The post shutdown inspection of the melter showed this was indeed the case.

Recommendation: The DWPF should monitor this ratio as an indication of a conductive accumulation on the DWPF melter floor. The individual circuit resistances should also be routinely monitored and trended with time. When feeds with higher noble metals concentrations are used estimates of noble metals settling should be trended. When noble metals accumulations approach 1-2 kg/ft of melter bottom, electrical disruption and electrode attack may occur.

Although there is an obvious trend of international vitrification facilities to move toward sloped bottom melters, this is not necessarily a viable alternative for the DWPF should problems occur. Firstly, the technical time and capital invested in the melt cell does not easily allow radical changes in the present melter design. A sloped bottom melter would require a redesign of the drain valve. Fortunately, melter design and testing in Germany and Japan has proceeded to include reliable drain valves that can function with noble metals. Other facilities have moved to sloped bottom melters. The smallest deviation from existing DWPF design and operating practice which appears technically feasible is a combination of 1) a bottom drain assembly of the German or Japanese type, which have been demonstrated to work with noble metals, 2) mechanical removal of melter bottom deposits after melter draining and cooling, and 3) raising and reshaping the bottom electrodes to minimize local current densities.

One modification to the DWPF melter which could be accommodated is the raising of the lower electrodes. It is not known what effect this would have on the operation of the melter with or without a conductive bottom layer. Mathematical models, however, do exist which can be used to predict the effects of such as modification.

Recommendation: Finite element mathematical models should be used to predict the effects of a modified electrode configuration in the DWPF melter.

The West Valley Demonstration melter is designed to be less susceptible to noble metals than the DWPF (which was designed in 1983). The WVDP modifications appear to have been partially successful, yet two-thirds of the electrical resistance in the WVDP melter circuits have been lost after one year of operation with noble metals concentrations comparable to SRS HM waste. WVDP is actively following the electrical response of its melter. 
Recommendation: DWPF and SRTC should actively participate in the work at WVDP concerning the electrical response of the WVDP melter, as well as follow their approach to dealing with these issues, which includes the following activities:

- trending of historical operating data;

- updating a computer model for use as a tool in predicting future melter performance, including power needs;

- remote sampling of deposits;

- remote probing the deposits to determine their location and depth; and

- developing remote tools to dislodge deposits of noble metals in situ and performing associated mockups, as applicable. 


\section{Acknowledgments}

Many people have contributed to the completion of this Task. The IDMS team, composed of Jack Zamecnik, Jim Ritter, Frances Williams, Don Miller, Mike Smith, Nick Odom, and Nick Hutson, have been responsible for conducting the IDMS runs. The PHEF team, comprised of Richard Edwards, Steve Young, Hasmukh Shah, and Dan Lambert conducted the runs to provide the PHA simulant for the IDMS runs. TNX Operations Section (formerly SRTC, now SRS Site Services) had the responsibility of daily operation, monitoring, and maintenance of both the IDMS and PHEF facilities. Dan Steedley, Mike Summer, and Jack Durden (SRTC ADS) provided all the Scanning Electron Microscopy support for this project while Mike Tosten (SRTC MTS) provided Transmission Electron Microscopy support. Mike Smith (SRTC IWT) coordinated the Monarch Analytical Services contract. Art Jurgensen (SRTC ADS) provided the XRF and XRD analyses. Carol Jantzen (SRTC IWT) assisted with discussions and advice concerning glass chemistry.

A special acknowledgment is offered to Nick Hutson (former SRTC member of the IDMS team ) who was the IDMS noble metals program coordinator, and who gathered much of the information in this report, including writing a first draft of this report before moving on to other responsibilities. 
- This page left intentionally blank - 


\section{References}

[1] N. D. HUTSON, "DWPT Technical Task Plan - IDMS Noble Metals Studies", USDOE Report WSRC-TR-90-0209, Savannah River Technology Center, Aiken, SC (1990).

[2] W. P. GRIFFITH, The Chemistry of the Rarer Platinum Metals (Os, Ru, Ir, and Rh), Interscience Publishers, a division of John Wiley and Sons, London, (1967).

[3] H. D. SCHREIBER, et. al., "Ruthenium in Glass-Forming Borosilicate Melts", Jour. of Less Common Metals, Vol. 115, pp. 145 - 154 (1986).

[4] Lange's Handbook of Chemistry, 13th Edition, John A. Dean, Editor, McGraw-Hill Book Company, New York (1985).

[5] D. F. BICKFORD, R. C. PROPST, and M. J. PLODINEC, "Control of Radioactive Waste-Glass Melters: Part 3 - Glass Electrical Stability", Advances in the Fusion of Glass, D. F. Bickford, et. al. (editors), The American Ceramic Society, Westerville, $\mathrm{OH}$, pp. 19.1 - 19.17 (1988).

[6] H. IGARASHI and T. TAKAHASHI, "The Draining of Noble Metals in Vitrified Nuclear Waste by a Melter with a Sloping Floor", Glass Technology, Vol. 32, No. 2, (April 1991.

[7] M. YOSHIOKA, et. al., "Glass Melter and Process Development for PNC Tokai Vitrification Facility", Waste Management, Vol. 12, pp. 7 - 16, (1992).

[8] J. T. CARTER, T. S. GUTMAN, N. D. HUTSON, R. A. PALMER, W. M. HARTY, and D. A. LAMAR, "United States Department of Energy Office of Environmental Restoration and Waste Management Trip Report - Tokai Vitrification Facility / Tokai Works" USDOE Report WSRC-RP-92-1392, Savannah River Technology Center, Aiken, SC (1992). (Documentation of a USDOE/PNC Melter Technology Workshop, Nov 18-19, 1992, Mito, Japan).

[9] H. WIESE and E. EWEST, "Industrial Vitrification of High Level Liquid Wastes in the PAMELA Plant", Proceedings of Waste Management '88 .Vol. 2, pp. 173- 179, Tucson, AZ (1988).

[10] W. TOBIE and S. WEISENBURGER, "Advanced Joule-Heated Nuclear Waste Glass Melters", Proceedings of the Symposium Waste Management '90, Vol. 2, Tucson, AZ (1990). 
[11] M. F. COOPER, et. al. "Research-Scale Melter Test Report", USDOE Report PNL9428, Battelle Pacific Northwest National Laboratory, Richland, WA (1994).

[12] W. GRUNEWALD, G. ROTH, W. TOBIE, and S. WEISENBURGER, "Progress Achieved in HLW Vitrification Techniques at INE", Proceedings of the 1993 International Conference on Nuclear Waste Management and Environmental Remediation, Prague, Czech Republic, The American Society of Mechanical Engineers, pp. 113 - 128 (1993).

[13] W. GRUNEWALD, G. ROTH, W. TOBIE, S. WEISENBURGER, and K. WEISS, "Vitrification of Noble Metals Containing NCAW-Simulant with an Engineering Scale Melter (ESM)", KfK-INE Campaign Report (Results of work performed under Contract No. 125818-A-A3 for Battelle Pacific Northwest National Laboratories), (1993).

[14] I. G. CHOI, "Effect of Natural Convection on Noble Metal Deposition Rate in a Melter", USDOE Report WSRC-RP-89-1250, Savannah River Technology Center, Aiken, SC 29808 (1989).

[15] M. L. ELLIOTT, et. al., "Preliminary Melter Performance Assessment Report", USDOE Report PNL-9822, Battelle Pacific Northwest National Laboratory, Richland, WA (1994).

[16] V. JAIN, S. M. BARNES, T.K. VETHANAYAGAM, and L.D. PYE, "Noble Metal and Spinel Deposition on the Floor of the Joule-Heated Ceramic Melter", Journ. Amer. Ceram Society, Vol. 74, No. 7, pp. 1559 - 62 (1991).

[17] M. E. SMITH, N. D. HUTSON, D. H. MILLER, J. MORRISON, H. B. SHAH, J. A. SHUFORD, J. GLASCOCK, F. H. WURZINGER, AND J. R. ZAMECNIK, "Checkout and Startup of the Integrated DWPF Melter System", USDOE Report WSRC-TR-89-0321, Savannah River Technology Center, Aiken, SC (1989).

[18] N. D. HUTSON, J. R. ZAMECNIK, M. E. SMITH, D. H. MILLER, and J. A. RITTER, "Integrated DWPF Melter System Campaign Report: Mercury Operation", USDOE Report WSRC-TR-91-0063, Savannah River Technology Center, Aiken, SC (1991).

[19] N. D. HUTSON, J. R. ZAMECNIK, M. E. SMITH, D. H. MILLER, and J. A. RITTER, "Integrated DWPF Melter System Campaign Report: The First Two Noble Metals Operations", USDOE Report WSRC-TR-91-0400, Savannah River Technology Center, Aiken, SC (1991). 
[20] J. R. ZAMECNIK, N. D. HUTSON, M. E. SMITH, D. H. MILLER, and J. A. RITTER, "Integrated DWPF Melter System Campaign Report: DWPF Cold Run Demonstration", USDOE Report WSRC-TR-93-0593, Savannah River Technology Center, Aiken, SC (1993).

[21] N. D. HUTSON, J. R. ZAMECNIK, J. A. RITTER, and J. T. CARTER, "Pilot Scale Processing of Simulated Savannah River Site High Level Radioactive Waste", Proceeding of the 1991 Joint International Waste Management Conference, Volume 2, Seoul, Korea (American Society of Mechanical Engineers, 1991).

[22] N. D. HUTSON, "Integrated DWPF Melter System (IDMS) Campaign Report: Hanford Waste Vitrification Plant Process Demonstration (U)", USDOE Report WSRC-TR-92-0403 (Rev 1), Savannah River Technology Center, Aiken, SC (1993).

[23] J. A. RITTER, J. R. ZAMECNIK, and C. W. HSU, "Hydrogen Generation During Treatment of Simulated High-Level Radioactive Waste With Formic Acid", Proceedings of the Third International Conference on High Level Radioactive Waste Management, Volume 1, Las Vegas, NV (1992).

[24] N. D. HUTSON and M. E. SMITH, "The Behavior and Effects of the Noble Metals in the DWPF Melter System", Proceedings of the Third International Conference on High Level Radioactive Waste Management, Volume 1, Las Vegas, NV (1992).

[25] N. D. HUTSON, "The Behavior of the Platinum Group Metals in a Borosilicate Waste Glass and Their Effects on the Operation of a Joule-Heated Melter", Ceramic Transactions. Nuclear Waste Management V, The American Ceramic Society, Westerville, $\mathrm{OH}$ (1993).

[26] W. T. COBB and P. HRMA, "Behavior of $\mathrm{RuO}_{2}$ in a Glass Melt", Ceramic Transactions, Nuclear Waste Management IV, The American Ceramic Society, Westerville, OH pp. 233 - 237. (1991).

[27] D. F. BICKFORD and C. M. JANTZEN, "Devitrification of Defense Nuclear Waste Glasses: The Role of Melt Insolubles", Journal of Non-Crystalline Solids, 84, pp. 299-307 (1986).

[28] C. KRAUSE and B. LUCKSCHEITER, "Properties and Behavior of the Platinum Group Metals in the Glass Resulting from the Vitrification of Simulated Nuclear Fuel Reprocessing Waste", Joumal of the Materials Research Society, Vol. 6, No. 12 (1991). 
[29] J. R. ZAMECNIK, "Release of Ammonia from HAN-Type PHA in DWPF Chemical Process Cell - Results of the IDMS HM4 Run", USDOE Report WSRC-TR-92-0302, Savannah River Technology Center, Aiken, SC (1992).

[30] C. J. COLEMAN, W. F. KINARD, N. E. BIBLER, D. F. BICKFORD, and W. G. RAMSEY, "Determination of Noble Metals in Savannah River Site High-Level Radioactive Sludge", SRC-MS-90-0262, Proceedings of Waste Management 1991, Tucson, Arizona (1991).

[31] C. M. JANTZEN, D. P. LAMBERT, "Inspection and Analysis of the Integrated DWPF Melter System (IDMS) after Seven Years of Operation (U)", USDOE Report WSRC-RP-96-575, Savannah River Technology Center, Aiken, SC (1996).

[32] I. G. CHOI, D. F. BICKFORD, and J. T. CARTER, "Thermal Effects of Electrically Conductive Deposits in a Joule-Heated Melter (U)", Proceedings from the Third International Conference on Advances in Fusion \& Processing Glass, New Orleans, Louisiana, (1992). 
APPENDIX:

(A) MONARCH ANALYTICAL DATA

\&

(B) STATISTICAL ANALYSIS OF IDMS UPPER/LOWER ELECTRODE RESISTANCES OVER TIME 


\section{APPENDIX A}

\begin{tabular}{|c|c|c|c|c|c|c|c|c|c|c|c|c|c|c|}
\hline Gloss 10 & Gloss Poured (10s) I & Totol Gloss Poured & $\operatorname{Ru}(p o m)$ & $P d(\mathrm{pgm})$ & Rh (pom) & $T_{\theta}(p g m)$ & Se (pom) & $A_{Q}(\mathrm{ppm})$ & Totd Ru & Totalpd & Total hn & Tota Te & Totase & TotalAO \\
\hline & & & & & & & & & Poured (oms) & Poured (oms) & Poured (oms) & Poured (oms) & Poured (oms) & Poured (oms) \\
\hline 3444 & 128 & 128 & $\overline{0}$ & 0 & 0 & 0 & 0 & 0 & 0 & 0 & 0 & 0 & 0 & 0 \\
\hline 3446 & 144 & 272 & 0 & 0 & 0 & 0 & 1 & 6 & 0 & 0 & 0 & 0 & 0 & 0 \\
\hline 3458 & 160 & 432 & 0 & 34 & 0 & 0 & 1.2 & 8 & 0 & 2 & 0 & 0 & 0 & $T$ \\
\hline 3461 & 175 & 607 & 0 & 44 & 0 & 0 & 1.8 & 11 & 0 & $\overline{6}$ & 0 & 0 & 0 & 2 \\
\hline 3471 & 163 & 770 & 0 & 52 & 0 & 24 & 2.2 & 14 & 0 & 10 & 0 & $\frac{2}{2}$ & 0 & 3 \\
\hline 3477 & 166 & 936 & 710 & 64 & 22 & 28 & $\overline{1.4}$ & 16 & 8 & 15 & 2 & 4 & $T$ & $A$ \\
\hline 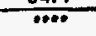 & 164 & 1100 & 125 & 68 & 24 & 30 & 2.1 & 17 & 18 & 20 & 3 & 6 & 1 & 5 \\
\hline 3488 & 105 & 1265 & 141 & 72 & 26 & 32 & 2.8 & 18 & 28 & 25 & 5 & 9 & 1 & 7 \\
\hline 3494 & 106 & 1431 & 105 & 82 & 30 & 30 & 2.9 & 21 & 36 & 31 & $\bar{B}$ & 11 & 1 & $\overline{8}$ \\
\hline 3499 & 125 & 1556 & 96 & 69 & 32 & 42 & 3.1 & 23 & 42 & 36 & 9 & 14 & $T$ & 10 \\
\hline 3502 & 157 & 1713 & 108 & 91 & 32 & 40 & 3.3 & 23 & 49 & 43 & 12 & 17 & 2 & 11 \\
\hline 3508 & $\frac{164}{164}$ & 1877 & 116 & 95 & 33 & 44 & 3.3 & 25 & 58 & 50 & 14 & 20 & 2 & 13 \\
\hline 3511 & 167 & 2044 & 105 & 99 & 34 & 47 & 3,2 & 25 & 6 & 57 & 17 & 23 & 2 & 15 \\
\hline 3516 & 154 & 2198 & 104 & 101 & 35 & 45 & 3.4 & 26 & 73 & 04 & 19 & 27 & 2 & 17 \\
\hline 3522 & 155 & 2353 & 108 & 100 & 34 & 44 & 3.2 & 25 & 81 & 71 & 22 & 30 & 3 & 19 \\
\hline 3527 & 150 & 2509 & 102 & 100 & 36 & 44 & 3.4 & 26 & 88 & 79 & 24 & 33 & $\sqrt{3}$ & 20 \\
\hline 3534 & 145 & 2654 & 110 & 100 & 36 & 48 & 3.9 & 25 & 95 & 85 & 27 & 36 & 3 & 22 \\
\hline 3540 & $\frac{140}{155}$ & 2809 & 88 & 97 & 34 & 46 & 3 & 25 & 101 & 92 & 29 & 39 & 3 & 24 \\
\hline 3604 & 161 & 2970 & $\frac{\pi}{0}$ & $\frac{11}{94}$ & 0 & 0 & 0 & 18 & 101 & $\Phi$ & 29 & 39 & $\frac{5}{3}$ & 25 \\
\hline & & & & $\therefore$ & & & & & & & & & & \\
\hline & & & & & & & & & & & & & & \\
\hline \multicolumn{2}{|c|}{ Totd ploss poured (ko) } & 1348.38 & & \multicolumn{3}{|c|}{ Per Boteh AddiltionValuos } & & & & \multicolumn{2}{|c|}{ Per MFT Somplo Values } & & & \\
\hline & & & & & & & & & & & & & & \\
\hline & 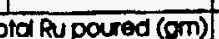 & 101 & ascharpe eft (RU) & TAS & RUS & dddod(cm) & 603.15 & & Doschorpe eff (Ru) & 39.0 & Ru odded (om) & 260 & & \\
\hline & td Pa poured (cm) & $\frac{101}{99}$ & Olschorge eff $(\mathrm{PC})$ & 27.9 & Pd & doded (om) & 354 & & Dsschorpe off $P$ Po & 76.0 & Pdodded (om) & 130 & & \\
\hline & tal An poured $(\mathrm{m})$ & $\frac{17}{29}$ & Discharce off(Rh) & 20.4 & & dod (on) & 141.6 & & Discharpe eff(Rn) & 57.9 & Phodded (om) & 50 & & \\
\hline & ord fo poured (om) & $\frac{69}{39}$ & Discharpe eff(te) & & TOC & $\operatorname{dded}(\mathrm{m})$ & & & Dischorge eff(te) & 58.0 & Te odded (om) & 70 & & \\
\hline & ofd se poured (pm) & $\frac{3}{3}$ & Clschorpe off (So) & & & dded (m) & & & Dischapoe eff (So) & 46.0 & Se codded (om) & 7 & & \\
\hline & to Ao poured (gm) & 25 & Dischanoe eff(AO) & 22.7 & AOC & dded (om) & 110.5 & & Discharge eff(Ao) & 83.8 & Acodded (om) & 30 & & \\
\hline
\end{tabular}




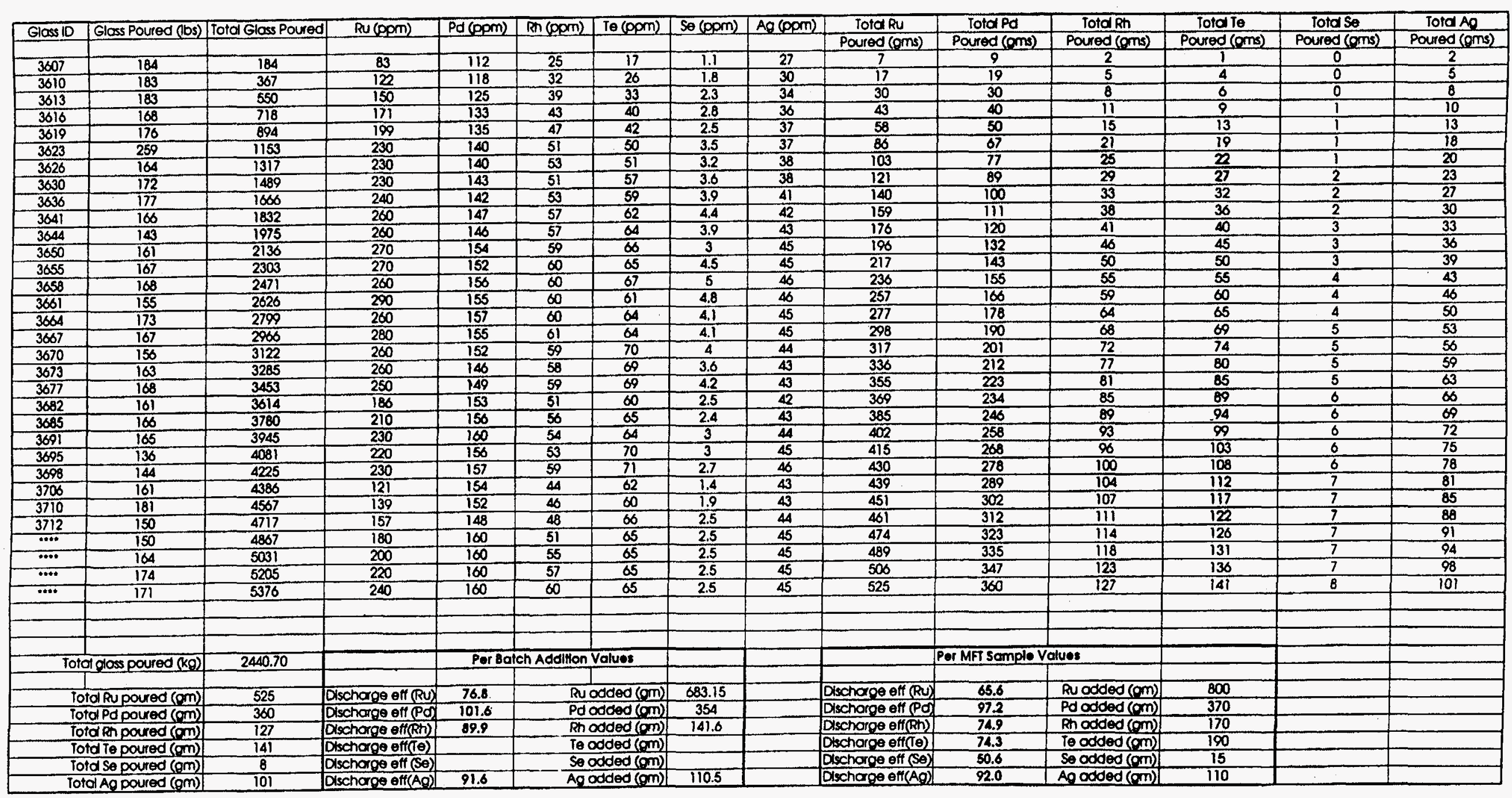




\begin{tabular}{|c|c|c|c|c|c|c|c|c|c|c|c|c|c|c|}
\hline Glas 10 & Gloss Poured (los) & Totol Glass Poured & $R u(p, p m)$ & Pd (ppm) & Rn (pom) & To (ppm) & se (ppm) & $A g(p p m)$ & Tota Ru & Total Pd & Totd Ph & Totd Te & Total $5 \theta$ & Toto $A Q$ \\
\hline & & & & & & & & & Poured (erns) & Poured (oms) & Poured (onts) & Poured (oms) & Poured (oms) & Poured (oms) \\
\hline $3951 \mathrm{~B}$ & 127 & 127 & 68 & 49 & 25 & 0 & 2 & 10 & 4 & 3 & $T$ & 0 & 0 & 1 \\
\hline 39668 & 172 & 299 & 120 & 70 & 33 & 29 & 2.6 & 13 & 13 & 8 & 4 & 2 & 0 & 2 \\
\hline 3964 & 106 & 465 & 188 & 90 & 43 & 42 & 3.5 & 17 & 27 & 15 & 7 & 5 & 1 & 3 \\
\hline$\cdots$ & 162 & 627 & 234 & 110 & 52 & 55 & 4 & 20 & 45 & 23 & 11 & 9 & I & 4 \\
\hline 39798 & 177 & 804 & 280 & 130 & 60 & 68 & 4.5 & 24 & 67 & 34 & 16 & 15 & $T$ & 6 \\
\hline 3996 & 148 & 952 & 320 & 140 & 63 & 77 & 5.3 & 26 & 89 & 43 & 20 & 20 & 2 & 8 \\
\hline 3993 & 162 & 1114 & 350 & 154 & 70 & 86 & 5.6 & 29 & 114 & 54 & 25 & 26 & 2 & 10 \\
\hline 40998 & 109 & 1223 & 370 & 177 & 79 & 96 & 7.5 & 32 & 133 & 63 & 29 & 31 & 2 & 12 \\
\hline 40988 & 157 & 1380 & 410 & 195 & 84 & 108 & 5 & 34 & 162 & 77 & 35 & 39 & 3 & 14 \\
\hline 41068 & 156 & 1536 & 380 & 195 & 81 & 107 & 6.2 & 35 & 189 & 91 & 41 & 46 & 3 & 17 \\
\hline 41138 & 160 & 1098 & 410 & 210 & 86 & 108 & 6 & 36 & 219 & 100 & 47 & 54 & 4 & 19 \\
\hline 4)198 & 162 & 1858 & 400 & 192 & 83 & 110 & 6.3 & 36 & 248 & 120 & 53 & 62 & 4 & 22 \\
\hline 41208 & 176 & 2034 & 430 & 199 & 80 & 108 & 5.8 & 35 & 282 & 136 & 60 & 71 & 5 & 25 \\
\hline 41268 & 176 & 2210 & 430 & 200 & 88 & 110 & 6 & 35 & 317 & 152 & 67 & 80 & 5 & 27 \\
\hline 4130 & 174 & 2384 & 450 & 195 & 87 & 112 & 6 & 34 & 352 & 167 & 74 & 89 & 5 & 30 \\
\hline $4132 B$ & 177 & 2501 & 410 & 186 & 03 & iII & 6.3 & 33 & 385 & 182 & 81 & 98 & 6 & 33 \\
\hline 4155 & 237 & 2798 & 450 & 210 & 92 & 125 & 5.4 & 38 & 434 & 205 & 91 & 111 & 7 & 37 \\
\hline \multirow[t]{3}{*}{4164} & 151 & 2949 & 500 & 230 & 99 & 134 & 6.6 & 43 & 468 & 221 & 97 & 120 & 7 & 40 \\
\hline & & & & & & & & & & & & & & \\
\hline & & & & $\therefore$ & & & & & & & & & & \\
\hline & & & & & & & & & & & & & & \\
\hline & & & & & & & & & & & & & & \\
\hline & & & & & & & & & & \multirow{2}{*}{\multicolumn{2}{|c|}{ Por MFT Somplo Values }} & & & \\
\hline \multicolumn{2}{|c|}{ Totol gloss poured (kg) } & 1338.85 & & Per Bal & =h Addition & Values & & & & & & & & \\
\hline & & & & & & & & & & & & & & \\
\hline & tol Ru poured (gm) & 468 & Dlscharge eff (Ru) & 31.0 & & dded (om) & 1511.4 & & Dscharge eff (RU) & 55.1 & Ru odded $(\mathrm{om})$ & 850 & & \\
\hline & tol Po poured (om) & 221 & Dischorpe eft (Po) & 41.4 & & dded (om) & 533.9 & & Discharpe off (Po) & 71.2 & Pd odded $(\mathrm{cm})$ & 310 & & \\
\hline & fol th poured (om) & 97 & Dischorpe eff(Rh) & 37.9 & & odded $(\mathrm{om})$ & 258.8 & & Dischorge eff(f(r) & 69.6 & Rh ooded (cm) & 140 & & \\
\hline & for Te poured (om) & 120 & Discharge eff(te) & & & dded $(\mathrm{om})$ & & & Dischorge eff(te) & 57.2 & Te odded (om) & 210 & & \\
\hline & tal se poured (gm) & 7 & Discharge eff (So) & & & dded $(\mathrm{m} n)$ & & & Dischorge off (Se) & 70.3 & $\operatorname{Se~odded~}(\mathrm{cm})$ & 10 & & \\
\hline & ol Ag poured (gm) & 40 & Discharge eff(AO) & 41.8 & $\mathrm{AOC}$ & dded (om) & 95.3 & & Dischorog eff(A) & 79.7 & Ag odded (om) & 50 & & \\
\hline
\end{tabular}




\begin{tabular}{|c|c|c|c|c|c|c|c|c|c|c|c|c|c|c|}
\hline Glass iD & Gloss Poured (1Ds) & Totol Gloss Poured & Ru (ppm) & Pd (ppm) & hi $(\mathrm{ppm})$ & $1 \theta(\mathrm{ppm})$ & Se (ppm) & $\mathrm{Ag}(\mathrm{ppm})$ & TotdRu & Totalpd & Total Rh & Tota To & Totol Se & TotdAQ \\
\hline & & & & & & & & & Poured (oms) & Poured (oms) & Poured (oms) & Poured (oms) & Poured (oms) & poured (oms) \\
\hline$\ldots$ & 151 & 151 & 400 & 250 & 80 & 125 & 5 & 40 & 27 & 17 & 5 & 9 & 0 & 3 \\
\hline$\cdots$ & 164 & 315 & 530 & 270 & 100 & 145 & $\delta$ & 45 & 67 & 37 & 13 & 19 & 1 & 6 \\
\hline 4186 & 153 & 468 & 660 & 290 & 119 & 165 & 8.5 & 50 & 113 & 57 & 21 & 31 & 1 & 10 \\
\hline 4194 & 146 & 614 & 690 & 300 & 127 & 173 & 11 & 53 & 158 & 77 & 30 & 42 & 2 & 13 \\
\hline 4199 & 150 & 704 & 690 & 310 & 126 & 173 & 10 & 54 & 205 & 98 & 38 & 54 & 3 & 17 \\
\hline 4207 & 176 & 940 & 710 & 300 & 121 & 180 & 10 & 54 & 262 & 122 & 48 & 68 & 4 & 21 \\
\hline 4214 & 156 & 109 & 710 & 320 & 136 & 181 & 7.1 & 57 & 312 & 145 & 57 & 81 & 4 & 25 \\
\hline$\ldots$ & 146 & 1242 & 675 & 310 & 131 & 179 & 7.5 & 55 & 357 & 166 & 66 & 93 & 5 & 29 \\
\hline 4234 & 168 & 1410 & 640 & 300 & 120 & 176 & 8.2 & 54 & 406 & 188 & 76 & 107 & 5 & 33 \\
\hline 4239 & 170 & 1580 & 700 & 320 & 138 & 184 & 9 & 54 & 460 & 213 & 86 & 121 & 8 & 37 \\
\hline 4284 & 172 & 1752 & 690 & 330 & 137 & 182 & 9.9 & 56 & 514 & 239 & 97 & 135 & 7 & 41 \\
\hline 4309 & 168 & 1920 & 640 & 300 & 126 & 178 & 0.9 & 54 & 563 & 262 & 107 & 149 & 7 & 46 \\
\hline 4344 & 160 & 2080 & 530 & 290 & 113 & 181 & 5.8 & 55 & 601 & 283 & 115 & 162 & 8 & 50 \\
\hline 4347 & 158 & 2238 & 580 & 300 & 118 & 190 & 6.6 & 56 & 643 & 304 & 123 & 175 & 8 & 54 \\
\hline$\cdots$ & 50 & 2288 & 615 & 310 & 124 & 192 & 7 & 57 & 657 & 311 & 126 & 180 & 8 & 55 \\
\hline$\ldots$ & 168 & 2456 & 650 & 320 & 132 & 194 & 7 & 58 & 706 & 336 & 136 & 194 & 9 & 59 \\
\hline 4364 & 158 & 2614 & 690 & 330 & 135 & 196 & 7.2 & 60 & 756 & 359 & 146 & 209 & 9 & 84 \\
\hline 4369 & 143 & 2757 & 680 & 330 & 133 & 196 & 9 & 61 & 800 & 381 & 155 & 221 & 10 & 68 \\
\hline 4374 & 180 & 2917 & 710 & 340 & 138 & 197 & 9.5 & 61 & 852 & 406 & 165 & 236 & II & 72 \\
\hline 4383 & 142 & 3059 & 570 & 300 & 117 & 189 & 9.6 & 56 & 888 & 425 & 172 & 248 & 11 & 76 \\
\hline 4388 & 98 & 3157 & 710 & 340 & 134 & 200 & 11 & 60 & 920 & 440 & 178 & 257 & 12 & 78 \\
\hline 4393 & 140 & 3297 & 710 & 330 & 138 & 196 & 10 & 59 & 965 & 461 & 187 & 269 & 12 & 82 \\
\hline \multirow[t]{4}{*}{$\cdots$} & 169 & 3466 & 710 & 330 & 138 & 196 & 10 & 60 & 1,020 & 486 & 198 & 284 & 13 & 87 \\
\hline & & & & & & & & & & & & & & \\
\hline & NOTE: IST TWOCA & ANS POURED HAD NK & OSAMPLE - BASED & ONHMRWH & CHWAS JUS & TEEFORE THK & SRUN & & & & & & & \\
\hline & & & & \multirow{2}{*}{\multicolumn{3}{|c|}{ Por Batch Additon Numbers }} & & & & & & & & \\
\hline \multirow{2}{*}{\multicolumn{2}{|c|}{ Totol glass poured (kg) }} & 1573.56 & & & & & & & \multicolumn{3}{|c|}{ Per MFT Somplo Volues } & & & \\
\hline & & & & & \multirow{2}{*}{\multicolumn{2}{|c|}{ Ru odded (gm) }} & & & & & & & & \\
\hline & 1.020 & Discharge off (RU) & 67.5 & & & 1511 & & Dischorge eff (RU) & 64.9 & Ru odded (om) & 1570 & & \\
\hline \multicolumn{2}{|c|}{ Iotol Pd poured (om) } & 486 & Discharge eff (PC) & 91.1 & \multicolumn{2}{|c|}{ Pdodded (om) } & 534 & & Dischorge eff (PO) & 97.3 & Pd odded $(\mathrm{gm})$ & 500 & & \\
\hline \multicolumn{2}{|c|}{ Totol hin poured $(\mathrm{cm})$} & 198 & Discharge eff(r) & 76.9 & \multicolumn{2}{|c|}{ Rh odded (om) } & 257 & & Dischorge eff(Rh) & 76.0 & Ph odded (om) & 260 & & \\
\hline \multicolumn{2}{|c|}{ Totd Te poured (om) } & 284 & Dsschorge aff(te) & & \multicolumn{2}{|c|}{ Te odded (om) } & & & Otschorge enf(T) & 81.2 & Te odded (om) & 350 & & \\
\hline \multicolumn{2}{|c|}{ Totd Se poured (gm) } & 13 & Dischorge eff (se) & & \multirow{2}{*}{\multicolumn{2}{|c|}{$\begin{array}{l}\text { Se odded (om) } \\
\text { Ag added (om) }\end{array}$}} & $\cdot$ & & Dischorge eff (Se) & 48.5 & Se odded (om) & 27 & & \\
\hline & Ag poured (gm) & 87 & Discharge e fff(Ag) & 91.1 & & & 95 & & Oischorge eff(AQ) & 96.2 & $A 000000(0 m)$ & 90 & & \\
\hline
\end{tabular}




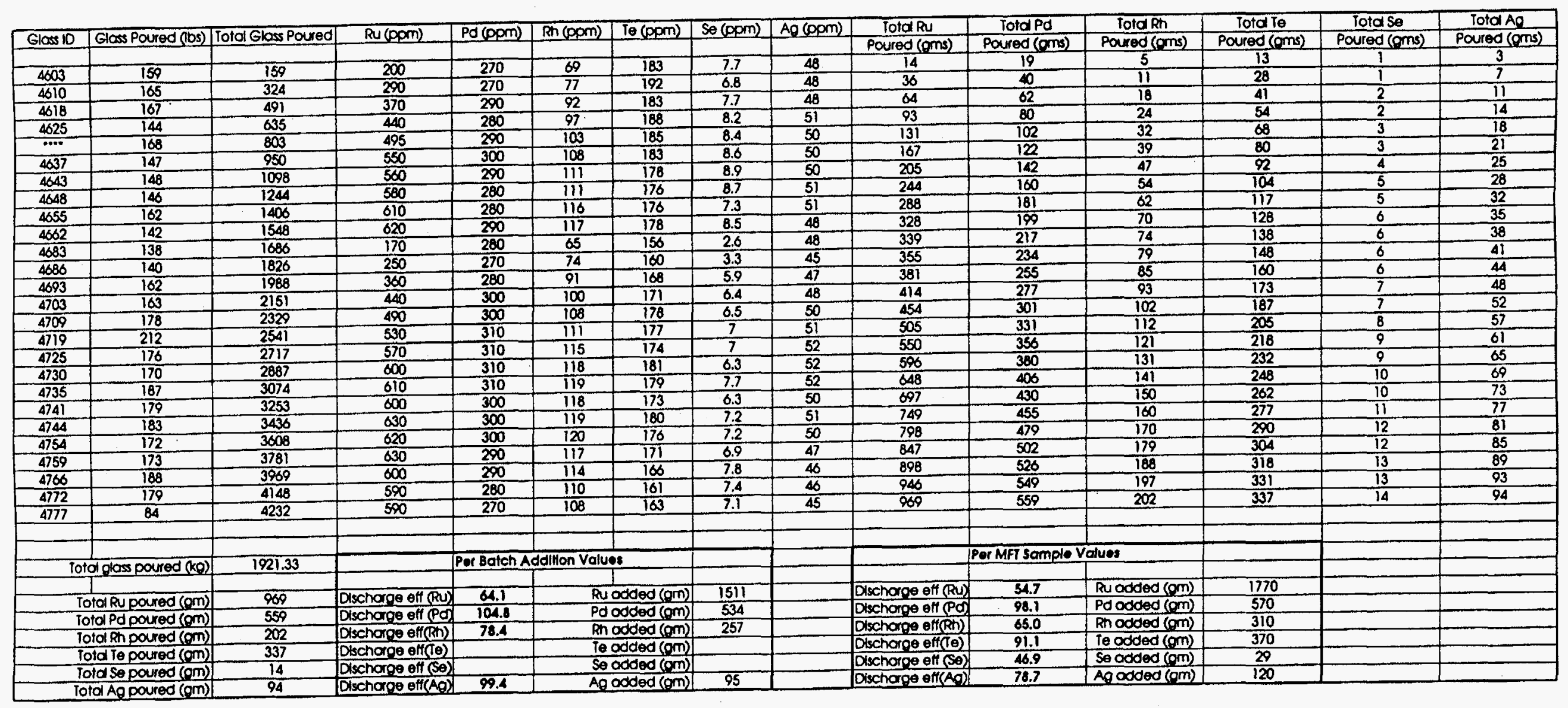




\begin{tabular}{|c|c|c|c|c|c|c|c|c|c|c|c|c|c|c|}
\hline Glos 10 & Gloss Poured (bs) & Totol Gloss Poured & $\mathrm{Ru}(\mathrm{pmm})$ & $\operatorname{Pd}(\mathrm{gpm})$ & Fin (ppm) & Te(pom) & Se (ppm) & $\mathrm{Ag}(\mathrm{ppm})$ & Total Ru & Totapd & ToldRn & Total Te & Tota Se & TotdAQ \\
\hline & & & & & & & & & Poured (oms) & Poured (oms) & Poured (oms) & Poured (orns) & Poured (pms) & Poured (oms) \\
\hline$\ldots$ & 174 & 174 & 250 & 220 & 61 & 180 & 2 & 45 & 20 & 17 & 5 & 14 & 0 & 4 \\
\hline 4454 & 162 & 336 & 340 & 240 & 78 & 180 & 4.3 & 52 & 45 & 35 & 11 & 27 & 0 & 7 \\
\hline 4459 & 158 & 494 & 430 & 260 & 95 & 186 & 6.3 & 57 & 76 & 54 & 17 & 4) & 1 & $\pi$ \\
\hline 4469 & 161 & 655 & 490 & 270 & 105 & 188 & $7 . \overline{3}$ & 60 & 111 & 73 & 25 & 55 & 1 & 16 \\
\hline 4473 & 147 & 802 & 530 & 280 & 109 & 194 & 9.3 & 59 & 147 & 92 & 32 & 67 & 2 & 20 \\
\hline 4483 & 172 & 974 & 540 & 280 & 109 & 198 & 9.3 & $\infty$ & 189 & 114 & 41 & 83 & 3 & 24 \\
\hline 4492 & 176 & 1150 & 590 & 300 & 118 & 196 & 11 & 56 & 236 & 138 & 50 & 98 & 4 & 29 \\
\hline$\cdots$ & 169 & 1319 & 610 & 300 & 120 & 190 & 12 & 53 & 283 & 161 & 59 & $\pi 13$ & 5 & 33 \\
\hline 4505 & 100 & 1479 & 630 & 290 & 122 & 183 & 12 & 51 & 329 & 182 & 68 & 126 & 5 & 37 \\
\hline 4508 & 181 & 1660 & 590 & 280 & 111 & 180 & 12 & 51 & 377 & 205 & 77 & 141 & 6 & 41 \\
\hline 4511 & 162 & 1822 & 670 & 290 & 123 & 186 & 13 & 53 & 426 & 226 & 86 & 155 & 7 & 45 \\
\hline 4518 & 145 & 1987 & 690 & 290 & 124 & 187 & 13 & 55 & 472 & 245 & 95 & 167 & 8 & 48 \\
\hline 4526 & 169 & 2) 36 & 660 & 300 & 121 & 191 & 13 & 55 & 522 & 260 & 104 & 182 & 9 & 53 \\
\hline 4535 & 163 & 2299 & 680 & 290 & 121 & 190 & 13 & 57 & 573 & 290 & 113 & 196 & 10 & 57 \\
\hline 4540 & 152 & 2451 & 690 & 280 & 122 & 191 & 14 & 56 & 620 & 309 & 121 & 209 & 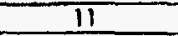 & 61 \\
\hline$\cdots$ & 156 & 2607 & 690 & 280 & 120 & 190 & 14 & 56 & 669 & 329 & 130 & 222 & 12 & 65 \\
\hline$\overline{4552}$ & 169 & 2776 & 680 & 280 & 119 & 187 & 13 & 56 & 721 & 351 & 139 & 237 & $\sqrt{13}$ & 69 \\
\hline 4560 & 154 & 2930 & 720 & 270 & 123 & 188 & 14 & 57 & 772 & 369 & 148 & 250 & 14 & 73 \\
\hline 4504 & 124 & 3054 & 890 & 270 & 119 & 185 & 15 & 55 & 871 & 385 & 154 & 260 & 15 & 76 \\
\hline 4571 & 154 & 3200 & 710 & 270 & 123 & 182 & 11 & 55 & 860 & 404 & 163 & 273 & 16 & 80 \\
\hline \multirow[t]{3}{*}{4578} & 136 & 3344 & 710 & 280 & 125 & 184 & 14 & 55 & 904 & 421 & 171 & 284 & 17 & 83 \\
\hline & & & & & & & & & & & & & & \\
\hline & & & & & & & & & & & & & & \\
\hline \multicolumn{2}{|c|}{ Iotd glas pour $\theta$ d $(\mathrm{kg})$} & 1518.18 & & Por $\mathrm{Ba}$ & Ch Addillion & Volves & & & & \multicolumn{2}{|c|}{ Por MFI Sample Values } & & & \\
\hline & & & & & & & & & & & & & & \\
\hline \multirow{2}{*}{\multicolumn{2}{|c|}{$\begin{array}{l}\text { Totol Ru poured (om) } \\
\text { Totol Pd poured (gm) }\end{array}$}} & 904 & Dischorge eff (Ru) & 59.8 & \multirow{2}{*}{\multicolumn{2}{|c|}{ Ru odded $(\mathrm{gm})$}} & $1 5 \longdiv { 1 . 4 }$ & & Dischage eff (Ru) & 66.5 & Ru odded (om) & 1360 & & \\
\hline & & 421 & Discharge eff (Po) & 78.8 & & & 533.9 & & Dischorge eff (Po) & 95.6 & Po odded (om) & 440 & & \\
\hline \multirow{2}{*}{\multicolumn{2}{|c|}{ Total Rh pourog (cm) }} & 171 & Dischorge eff(Rn) & 66.4 & \multicolumn{2}{|c|}{ Rh odded $(\mathrm{gm})$} & 256.8 & & Dischorge eff(Rn) & 77.5 & RT odded (om) & 220 & & \\
\hline & & 284 & Dischorge eff(te) & & \multicolumn{2}{|c|}{ Te odded $(\mathrm{mm})$} & & & Discharge eff(te) & 129.3 & Te odded $(\mathrm{gm})$ & 220 & & \\
\hline \multicolumn{2}{|c|}{$\begin{array}{l}\text { Totol Te poured (om) } \\
\text { Totd Se poured (gm) }\end{array}$} & 17 & Olschorge eff $(\mathrm{SO})$ & & \multirow{2}{*}{\multicolumn{2}{|c|}{$\frac{\text { Se odded (om) }}{\text { Ag added (om) }}$}} & & & Dischorpe eff (Se) & 72.4 & \begin{tabular}{|l|l|} 
Se odded (om) \\
\end{tabular} & 23 & & \\
\hline \multicolumn{2}{|c|}{$\frac{\text { Total se poured }(\mathrm{gm})}{\text { Total Ao poured }(\mathrm{gm})}$} & 83 & Dischorge elf(Ag) & 87.4 & & & 95.3 & & Discharge eff(Ag) & 92.6 & Ag odded (gm) & 9 & & \\
\hline
\end{tabular}


HWFORDI SPRSO-NWWAS

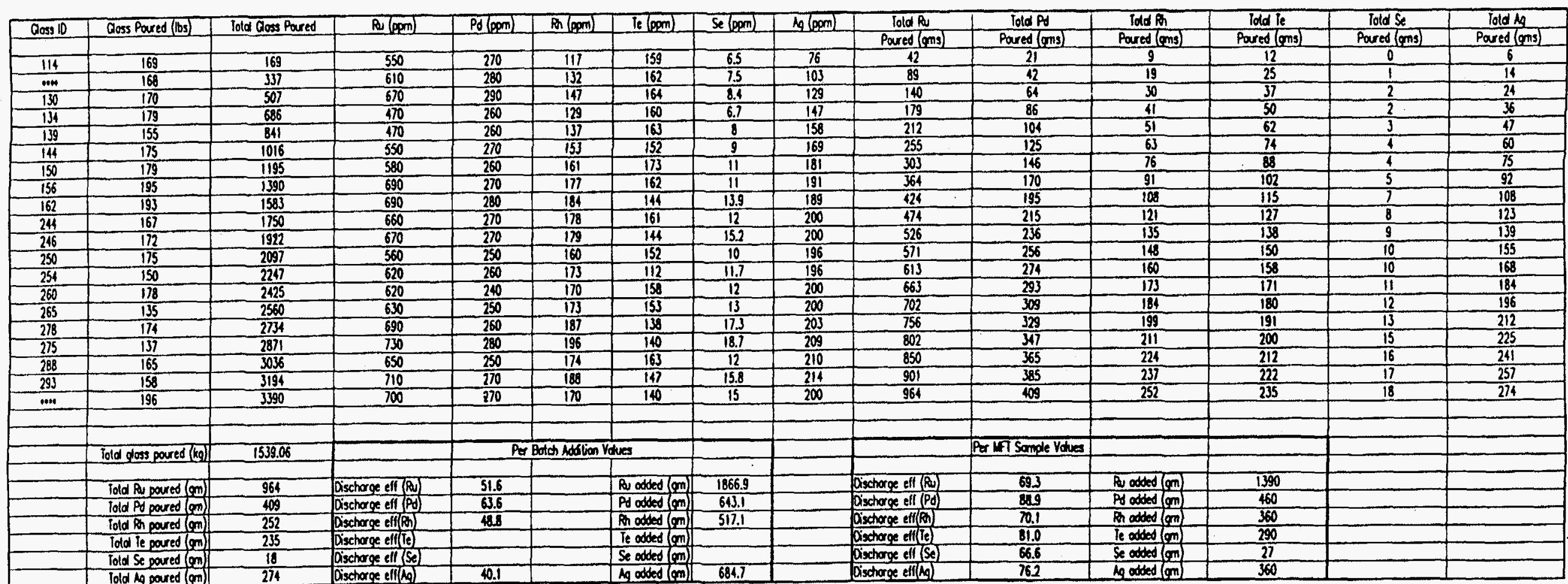




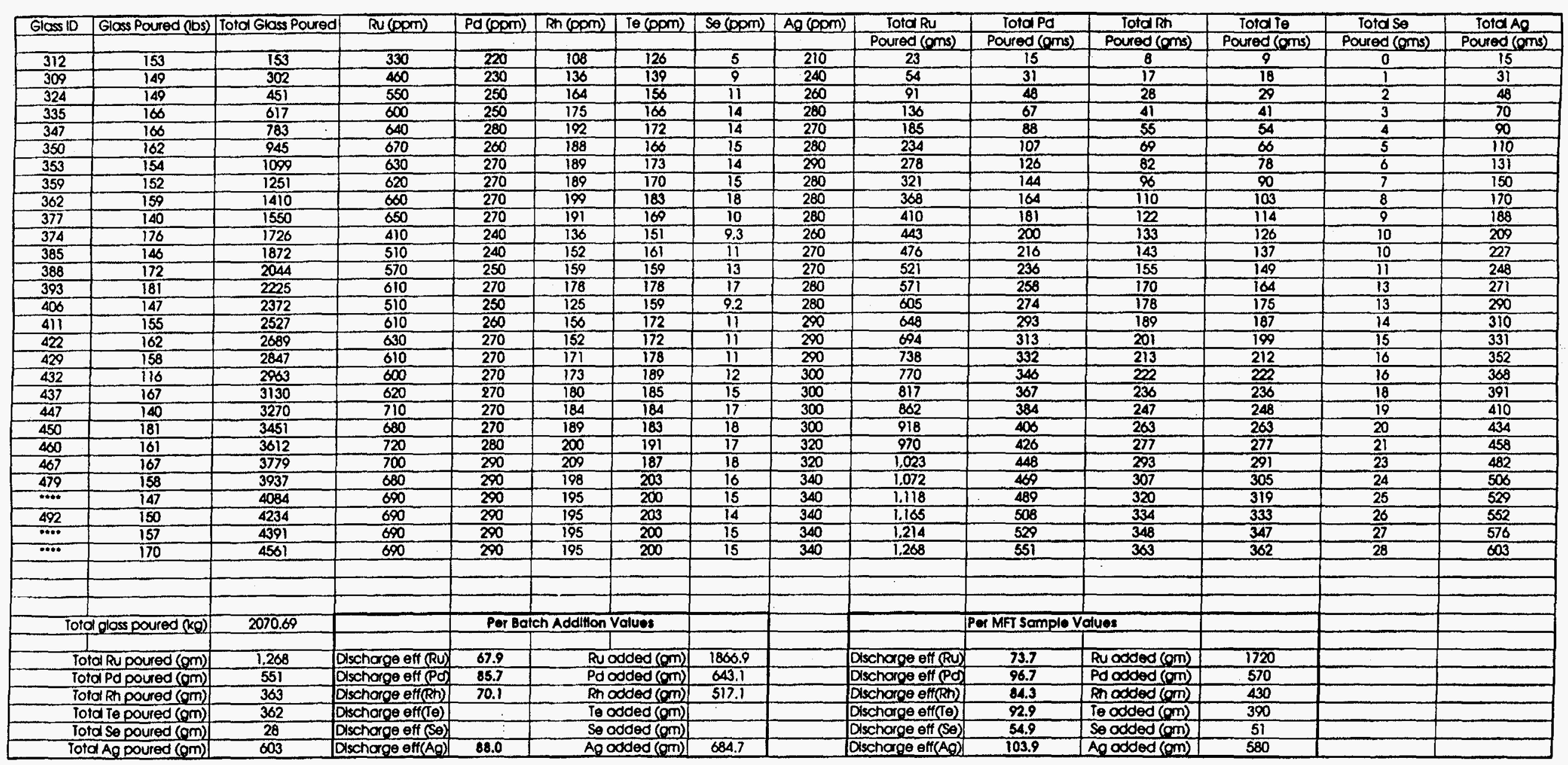




\begin{tabular}{|c|c|c|c|c|c|c|c|c|c|c|c|c|c|c|}
\hline Gloss 10 & Glass Poured (10s) & Total Glass Poured & $R \cup(p p m)$ & Pd (ppm) & $\operatorname{Rh}(p p m)$ & Io (ppm) & Se(ppm) & $\mathrm{Ag}(\mathrm{pom})$ & TotdRu & Totol Pd & TotdRh & Totale & Totase & Totol $A Q$ \\
\hline & & & & & & & & & Poured (oms) & Poured (oms) & Poured (oms) & Poured (oms) & Poured (oms) & Poured (ems) \\
\hline 5277 & 150 & 150 & 330 & 193 & 98 & 103 & 2.3 & 196 & 22 & 13 & 7 & 7 & 0 & 13 \\
\hline 5278 & 145 & 295 & 360 & 200 & 105 & $\Pi 14$ & 3.4 & 191 & 46 & 26 & 14 & 15 & 0 & 26 \\
\hline 5275 & 147 & 442 & 400 & 220 & 112 & 121 & 3.7 & 177 & 73 & 41 & 21 & 23 & I & 38 \\
\hline 5279 & 145 & 587 & 450 & 230 & 124 & 133 & 5.3 & 160 & 102 & 56 & 29 & 31 & 1 & 48 \\
\hline$\cdots$ & 147 & 734 & 490 & 240 & 130 & 141 & 6.5 & 150 & 135 & 72 & 38 & 41 & $i$ & 58 \\
\hline 5245 & 157 & B91 & 530 & 250 & 135 & 149 & $B$ & 139 & 173 & 90 & 48 & 51 & 2 & 68 \\
\hline 5251 & 144 & 1035 & 540 & 250 & 134 & 159 & 9.8 & 129 & 200 & 106 & 56 & 62 & 3 & 77 \\
\hline 5254 & 150 & 1185 & 510 & 250 & 130 & 157 & 9 & 125 & 243 & 123 & 65 & 72 & 3 & 85 \\
\hline$\cdots$ & 157 & 1342 & 515 & 260 & 130 & 160 & 9 & 117 & 280 & 142 & 74 & 84 & 4 & 93 \\
\hline 5262 & 126 & 1468 & 520 & 270 & 131 & 163 & 9 & 109 & 309 & 157 & 82 & 93 & 4 & 100 \\
\hline 5267 & 113 & 1581 & 550 & 270 & 138 & 169 & 9.4 & 111 & 336 & 171 & 89 & 102 & 5 & 105 \\
\hline 5272 & 146 & 1727 & 580 & 290 & 132 & 170 & 11 & 90 & 378 & 190 & 98 & 113 & 6 & III \\
\hline$\cdots$ & 125 & 1852 & 160 & 200 & 60 & 100 & 2 & 70 & 385 & 202 & 101 & 119 & 6 & 115 \\
\hline 5637 & 137 & 1989 & 160 & 210 & 69 & 105 & 2.9 & 70 & 398 & 215 & 105 & 125 & 6 & 120 \\
\hline 5645 & 138 & 2127 & 220 & 220 & 80 & 114 & 3.7 & 68 & 409 & 220 & 110 & 132 & 6 & 124 \\
\hline 5653 & 144 & 2271 & 300 & 210 & 86 & 118 & 4,4 & 69 & 429 & 242 & 116 & 140 & 6 & 128 \\
\hline 5658 & 128 & 2399 & 340 & 230 & 93 & 119 & 5.8 & 65 & 449 & 256 & 121 & 147 & 7 & 132 \\
\hline 5667 & 117 & 2510 & 370 & 230 & $\infty$ & 130 & 6.4 & 64 & 468 & 268 & 127 & 154 & 7 & 136 \\
\hline 5669 & 128 & 2644 & 420 & 230 & 102 & 133 & 7.9 & $\Delta 3$ & 493 & 281 & 133 & 162 & 8 & 138 \\
\hline 5673 & 164 & 2808 & 450 & 240 & 107 & 135 & 9.5 & 61 & 526 & 298 & 141 & 172 & 8 & 144 \\
\hline 5676 & 150 & 2958 & 470 & 240 & 109 & 130 & 9.9 & 55 & 558 & 315 & 148 & 181 & 9 & 148 \\
\hline$\ldots$ & 105 & 3063 & 470 & 240 & 109 & 130 & 9.9 & 55 & 581 & 327 & 153 & 187 & 9 & 150 \\
\hline \multirow[t]{4}{*}{5752} & 163 & 3226 & 210 & 210 & 83 & 132 & 7 & 56 & 598 & 342 & 159 & 197 & 10 & 154 \\
\hline & & & & & & & & & & & & & & \\
\hline & & & & & & & & & & & & & & \\
\hline & & & & & & & & & & & & & & \\
\hline \multicolumn{2}{|c|}{$\frac{1}{\text { Totcl gloss poured (kg) }}$} & 1464.00 & & \multicolumn{3}{|c|}{ Per Bolch Addition Volues } & & & & \multicolumn{2}{|c|}{ Per MFT Somple Values } & & & \\
\hline & & & & & & & & & & & & & & \\
\hline & fol Ru poured (om) & 596 & Dischorge off (Ru) & 39.5 & & $\operatorname{added}(\mathrm{mm})$ & 15ा1 & & Dischorge off (RU) & 64.8 & Ru odded (om) & 920 & & \\
\hline & fol Po poured $(\mathrm{gm})$ & 342 & Discharpe eff (PA) & 64.1 & & $\operatorname{added}(\mathrm{om})$ & 534 & & Discharge eff (Po) & 103.8 & Pdadded $(\mathrm{m})$ & 330 & & \\
\hline & tol fh poured (om) & 159 & Dischorge eff(Rn) & 62.0 & & $\operatorname{dded}(\mathrm{om})$ & 257 & & Dischorge eff(th) & 88.6 & Rli odded (om) & 180 & & \\
\hline & tol To poured (om) & 197 & Dischorge eff(t $(1)$ & & & ddded (on) & & & Dsschorge eff(T) & 103.5 & To odded (om) & 190 & & \\
\hline & lal Se poured (gm) & 10 & Discharge eff (se) & & & added (om) & & & Dischorpe eff (Se) & 55.1 & Se odded (em) & 18 & & \\
\hline To & dAg poured (om) & 154 & Dischorge eff( $\left.A_{0}\right)$ & 162.5 & $\overline{A O C}$ & $\operatorname{added}(\mathrm{am})$ & 95 & & Dischorge off $(A O)$ & 192.9 & Ac added (om) & 80 & & \\
\hline
\end{tabular}




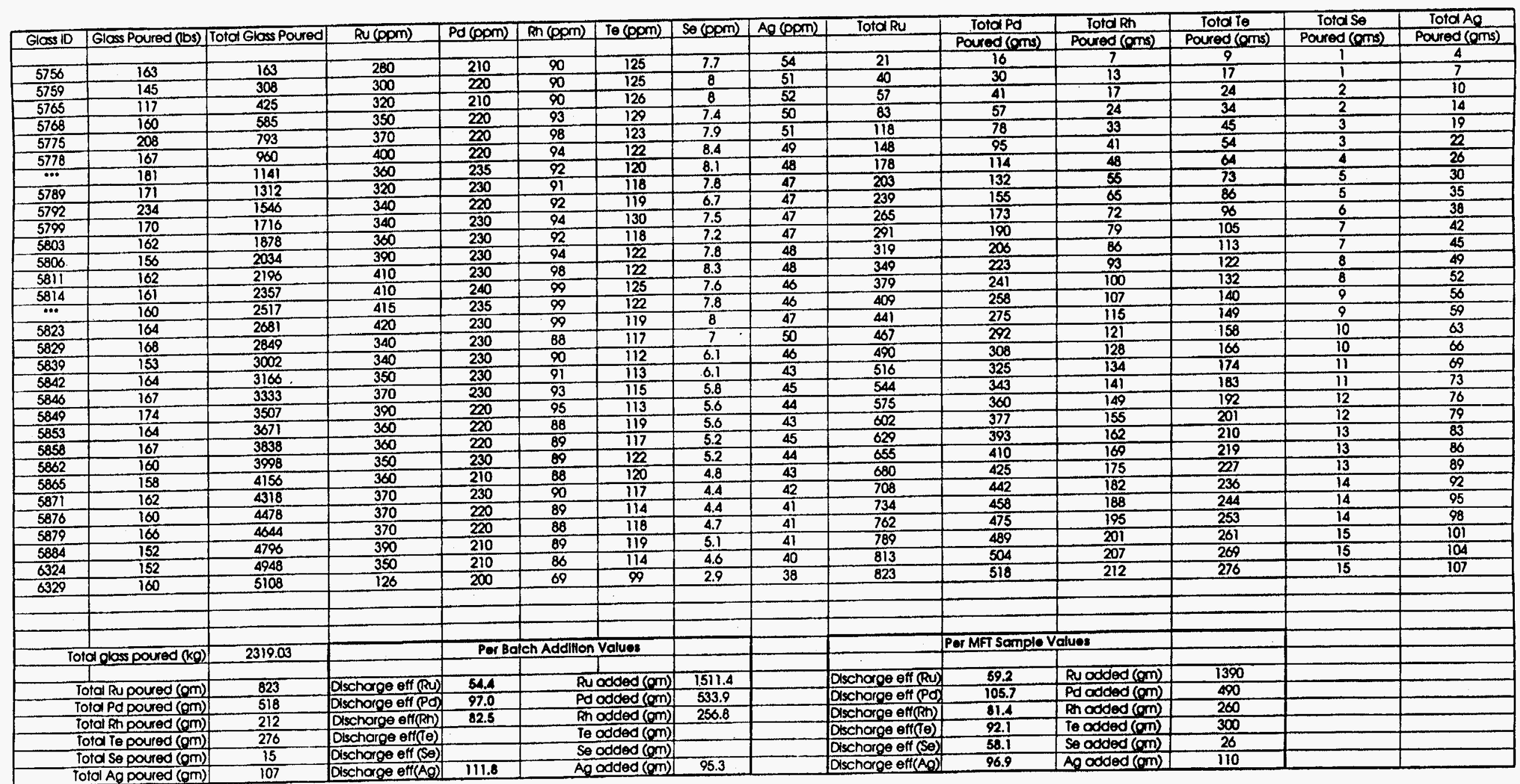




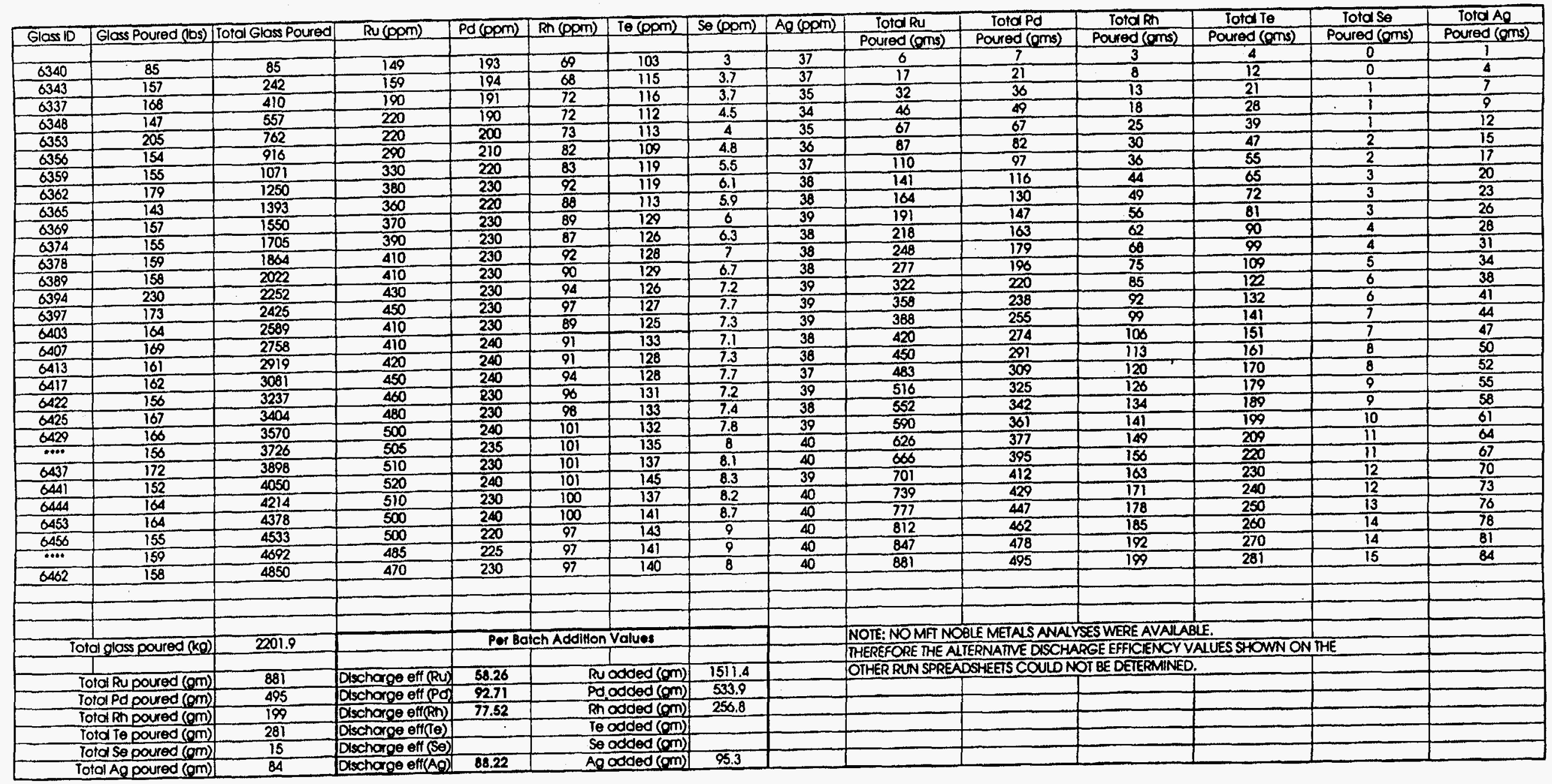


Appendix: $B$

Statistical Analysis of The Effect of Noble-Metal Fission-Product Deposition

on Electrical Shorting As Indicated by the Electrode Impedance Ratio of Waste-Glass Melters

\section{INTRODUCTION}

Melters are being developed for the conversion of high-level radioactive waste to borosilicate glass for permanent disposal. Operation of waste-glass melters treating simulated and actual commercial power reactor wastes indicated that noble-metal fission-product accumulation on melter floors can lead to distortion of electric heating patterns. This may decrease melter life, since any loss of electrical resistance from the formation of conductive phases reduces the power available for the melting process. Changes in melter geometry bave been developed in Japan and Germany to reduce this effect. The two existing melters for the U.S. Department Energy's Defense Waste Processing Facility were designed in 1982, before this effect was known or characterized. Pilot scale tests are being conducted in the Integrated DWPF Melter System (IDMS) to determine if the effect is significant for U.S. defense wastes, and if the effect can be diagnosed and corrected without significant damage or changes to the melter design.

\section{LTERATURE REVIEW}

Platinum group metals are produced by irradiation in nuclear reactors. The solubility of these metals is low in glass even at $1150^{\circ} \mathrm{C}$ [1]. The Japanese Power and Nuclear Fuel Development Corporation produced 3.5 tonnes of simulated waste-glass containing $0.74 \% \mathrm{RuO}_{2}, 0.11 \% \mathrm{Rh}, 0.30 \% \mathrm{Pd}$, and $0.02 \% \mathrm{Ag}$ [2]. At the end of the test, the electrical field in the melter was distorted to the point where glass processing could not continue. The deposits were a mixture of $\mathrm{RuO}_{2}$, and alloys of $\mathrm{Pd} / \mathrm{Te}$ and $\mathrm{Ru} / \mathrm{Rh}$. Similar results were reported in tests in Europe $[3,4]$. The concentration ratios of the Japanese to U.S. feeds are typical of the difference in concentrations between commercial reprocessing wastes and defense wastes (Ru 18:1, Rh 14:1, Pd 1500:1, and $\mathrm{Ag} 3: 1)$ [5].

These results suggested that the DWPF melter could experience significant distortion of power from the bottom electrode pair after about 150 melter throughputs, or about 1.5 years of continuous operation. Physical modeling of melter electrical patterns was evaluated for typical U.S. waste-glass [5]. See Figure 1. It was concluded that major melter design changes should not be necessary, provided that minor alterations in melter electrode design and monitoring of electrical characteristics could provide protection from shorting if noble metals accumulate [5].

\section{METHODS}

The IDMS melter is one-nineth (1/9) the capacity of the existing DWPF production melters, with two pairs of electrodes, similar to the DWPF electrode geometry. Ovier a period of two and one-half years 17,620 grams of noble metals have been fed to the IDMS melter, at concentrations typical of U.S. defense wastes. During this period the voltage and electrical currents necessary to maintain operating temperatures were recorded twice daily. Impedances were calculated by dividing the voltage (volts, 60 cycle AC) by current (amps). The calculated impedance of the top electrode pair was divided by the corresponding impedance of the bottom pair in an attempt to minimize effects caused by temperature and melt composition variations, as recommended by Reference 5 . Missing data points and some conditions with temporary high resistances were not evaluated. Figure 2 indicates the electrode impedances and the corresponding ratios for the 906 useable data points.

\section{RESULTS}

A least squares regression of the overall data was calculated and is plotted in Figure 2. The test results were divided into three subsets to determine if the correlation coefficient could be improved. The two major subsets consisted of data from 1,180 to 11,560 grams of noble metals fed (B), and from 11,560 to 17,620 grams fed (C). The average and standard deviation of the impedance ratio was calculated for each 
of these two subsets, and for the final cluster of data (D). The least squares regressions were calculated for each of the subsets, and are plotted for the two major subsets $(B \& C)$ in Figure 3. Statistical results are summarized in Table I, and hypothesis tested in Table II below.

TABLE I

RESULTS OF STATISTICAL ANALYSES OF IMPEDANCE RATIOS

\section{DATA GRAMS TO \\ SET \\ MELTER}

$\begin{array}{llll}\text { A } & 1,180-17,620 & 1.247 & 0.1811 \\ \text { B } & 1,180-11,560 & 1.199 & 0.1438 \\ \text { C } & 11.560-17,620 & 1.353 & 0.2077 \\ \text { D } & 14,590-17,620 & 1.414 & 0.2158\end{array}$
RATIO

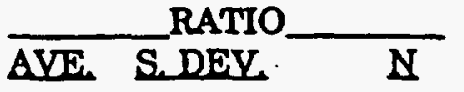

\section{6}

733

284

193

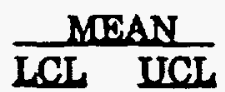

1.24

1.19 . 1.21

$1.33 \quad 1.38$

$1.38 \quad 1.44$

$\frac{\text { REGRESSION }}{\beta_{1}}$ STD ERROROF $\beta_{1}$

1.283E-5

$-1.512 \mathrm{E}-6$

$5.520 \mathrm{E}-5$

8.186E-5
9.820E-7

$1.270 \mathrm{E}-6$

4.456E-6

9.597 E-6

$\mathrm{N}=$ number of data points: Some values are shared between data subsets, e.g. at 11,560 grams . Pooled Std. Dev. of 1,180 to 11,560 and 11,560 to 17,620 subsets is 0.1641 , with greater than 240 degrees of freedom.

LCL = Lower Confidence Limit of Mean, at 95\% confidence level. UCL = Upper Confidence $\cdot$ Limit of Mean, at 95\% confidence level.

$\beta_{1}=$ Regression Coefficient for slope of Impedance Ratio vs. Grams Noble Metals.

T.S.: $t=$ (Average of data - Mean of population) / [std. dev. / square root (number of samples)]) $t=\beta_{1} /$ std. error of $\beta_{1}$

TABLE II

HYPOTHESIS TESTING OF IMPEDANCE RATIOS

NURLHXPQ

$$
\begin{aligned}
& \bar{X}_{B}=\bar{X}_{C}=0 \\
& \beta_{1, A}=0 \\
& \beta_{1, B}=0 \\
& \beta_{1, C}=0 \\
& \beta_{1, D}=0
\end{aligned}
$$

$\begin{aligned} & \text { RESEARCH } \\ & \bar{X}_{B}<\bar{X}_{C} \\ & \beta_{1, A}>0 \\ & \beta_{1, B}>0 \\ & \beta_{1, C}>0 \\ & \beta_{1, D}>0\end{aligned}$

$\mathbf{t}_{0.05}$

1.645

1.645

1.645

1.645

1.658 $\mathbf{t}$ CALCULATED

$-11.47$

13.07

$-1.19$

12.39

8.53

\section{CONCLUSION}

$\overline{\mathrm{X}}_{\mathrm{B}}<\overline{\mathrm{X}}_{\mathrm{C}}$
$\beta_{1, A}>0$
$\beta_{1, B}=0$
$\beta_{1, C}>0$
$\beta_{1, D}>0$

\section{DISCUSSION}

The overall effect was an increase in the impedance ratio as the test progressed. This is proven by use of the $t$-statistic to examine the difference of the averages of data sets $A$ and $C$, and is significant at the $95 \%$ confidence level. This is further demonstrated by the $t$-statistic of the standard error of $\beta_{1}$ of data set $A$ (overall data), which proves that the overall data has a positive slope. No significant shift occurred in the impedance ratio between 1,180 and 11,560 grams of noble metals added to the $1 / 9$ scale melter, since the calculated t-statistic is less than the critical value for this portion of the test. The impedance ratios increased significantly at the $95 \%$ confidence level for the two final sets of the test data $(C$ and $D)$ since the $t$ statistic of each $\beta_{1}$ is less than the critical value.

Significant electrical shifts have been measured in a $1 / 9$ scale version of the DWPF melter after feeding of 17,620 grams of noble metals as simulated fission products. No statistically significant shift in melter power occurred during the first 11,560 grams of noble metals fed to the melter. Pilot scale tests confirm the earlier physical modeling, and conclude that the effect will be detectable and quantifiable before damage to the bottom electrodes occurs. 


\section{REFERENCES}

[1] H.D. Schreiber, et al, "Ruthenium in Glass-Forming Borosilicate Melts", J. Less-Common Metals, 115 (1986) 145-154.

[2] N. Sasaki, et al,"Solidification of the High-Level Liquid Waste from the Tokai Reprocessing Plant", ANS Inter. Meeting Fuel Reprocessing \& Waste Man, Jackson WY, August, 1984.

[3] J.B. Morris, et al, "Electrode Corrosion and Ruthenium Behavior in a Small Joule Ceramic Melter", UKAEA Report AERE R 12349, October 1986.

[4] M. Steble, Deutsche Gesellschaft fur Wiederaufarbeitung von Kernbrennstoffen mbH (DKW), Presentation at Pacific Northwest Lab., April, 1987.

[5] - D.F. Bickford, R.C. Propst, and M.J. Plodinec, "Control of Radioactive Waste-Glass Melters: Part 3- Glass Electrical Stability", Advances in the Fusion of Glass, (Am. Ceramic Soc. , 1988) 19.1-19.17 . 


\section{FIGURE 2}
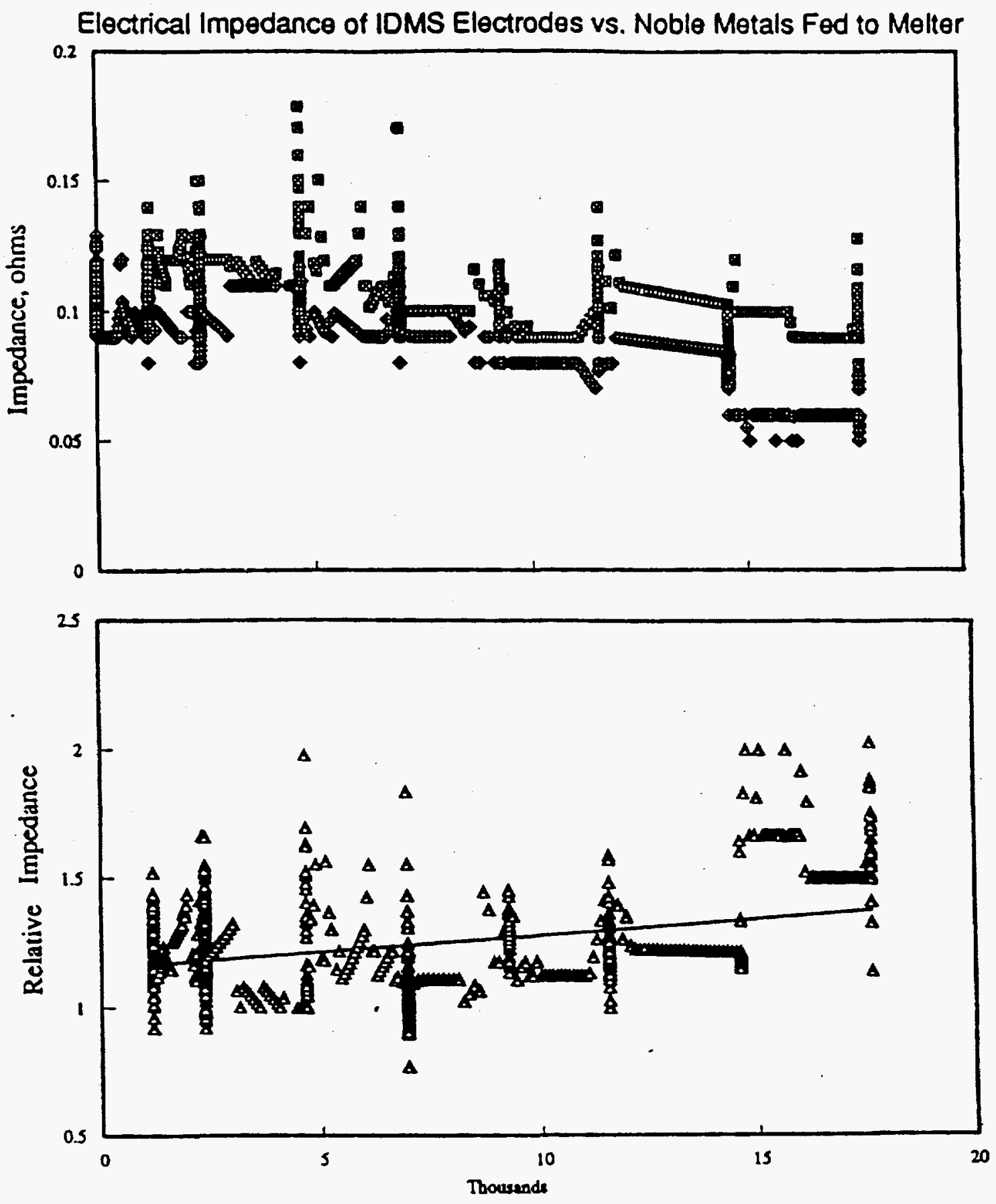

Total Noble Metals Fed to Melter, grams

$\Delta$ Top Imp. / Bottom Imp. _ Least Squares Fit

- Top Electrodes $\quad$ Bottom Electrodes 
FIGURE 3
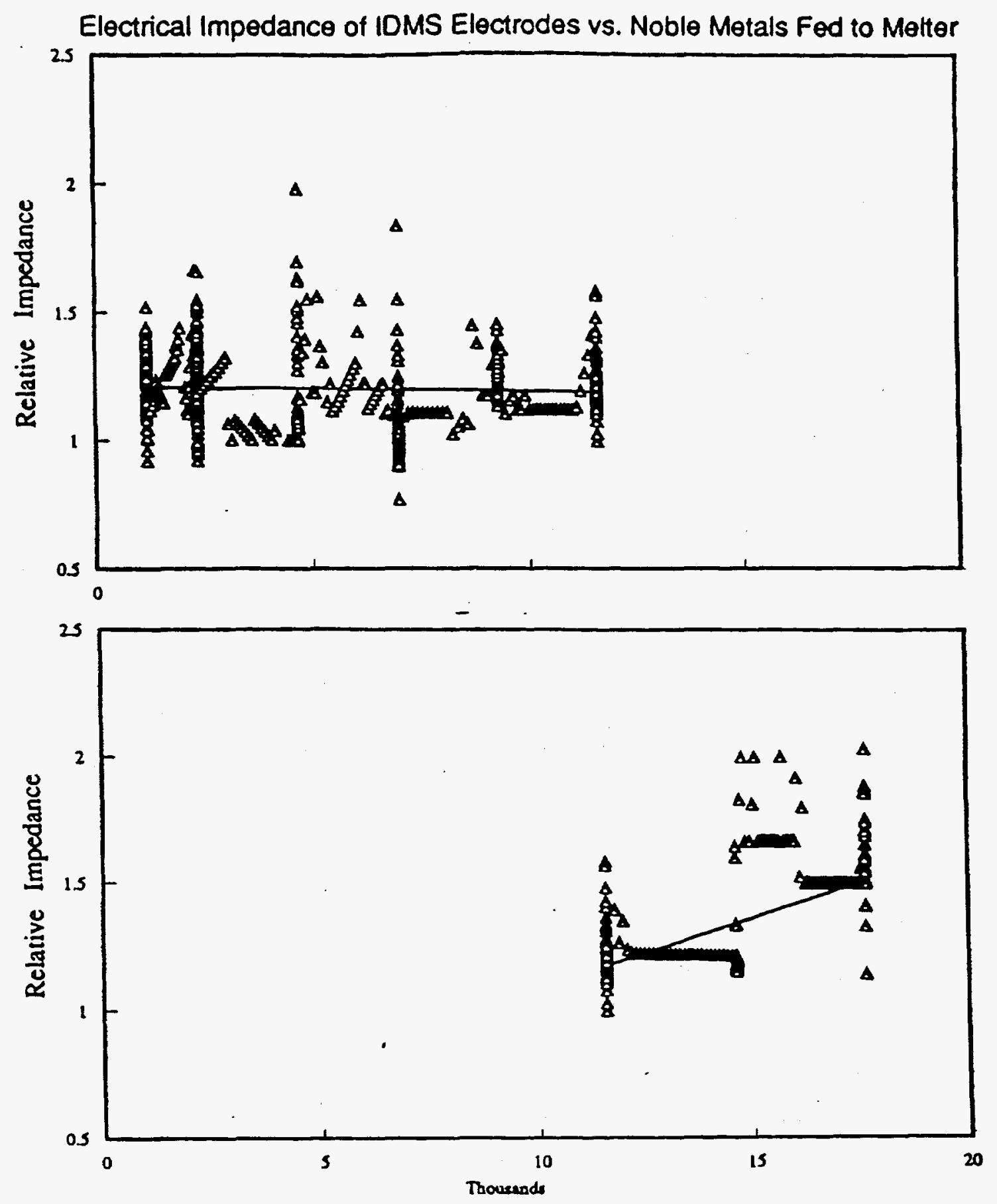

Total Noble Metals Fed to Melter, grams

ه Top Imp. / Bottom Imp. —_Least Squares Fit 
WSRC-TR-97-00370, Rev. 0

\section{DISTRIBUTION:}

E. W. Holtzscheiter, 773-A

J. R. Harbour, 773-43A

C. R. Goetzman, 773-A

B. J. Hardy, 704-1T

D. A. Crowley, 773-43A

C. A. Cicero-Herman, 773-41 A

L. F. Landon, 704-1T

D. T. Herman, 704-1T

C. T. Randall, 704-T

M. K. Andrews, 773-A

R. A. Jacobs, 704-T

C. Bannochie, 773-A

C. M. Jantzen, 773-A

D. C. Beam, 773-A

T. M. Jones, 704-1T

S. B. Beck, 704-T

D. P. Lambert, 704-1T

D. R. Best, 773-A

J. C. Marra, 773-43A

N. E. Bibler, 773-A

K. M. Marshall, 773-43A

D. F. Bickford, 773-43A

D. H. Miller, 704-1T

P. R. Monson, 704-1t

K. G. Brown, 704-1T

J. M. Pareizs, 773-A

P. R. Burkett, 704-T

T. B. Calloway, Jr., 773-41 A

D. K. Peeler, 773-43A

A. S. Choi, 704-1T

A. Cozzi, 773-A

C. L. Crawford, 773-41A

W. E. Daniel, 704-1T

R. E. Eibling, 704-1T

A. P. Fellinger, 704-1T

T. L. Fellinger, 773-A

E. M. Frickey, 773-23A

R. F. Schumacher, 773-43A

F. G. Smith, III, 704-1T

M. E. Smith, 773-43A

T. K. Snyder, 704-T

M. E. Stone, 704-T

G. E. Weeks, 704-1T

M. F. Williams, 704-1T

D. C. Witt, 704-1T

J. R. Zamecnik, 773-41 A

STI, 703-43A (4) 